UNIVERSIDADE DE SÃO PAULO

ESCOLA DE ENFERMAGEM

PATRÍCIA PONCE DE CAMARGO

\title{
PROCEDIMENTO DE INSERÇÃO, MANUTENÇÃO E REMOÇÃO DO CATETER CENTRAL DE INSERÇÃO PERIFÉRICA EM NEONATOS
}




\section{PATRÍCIA PONCE DE CAMARGO}

\section{PROCEDIMENTO DE INSERÇÃO, MANUTENÇÃO E REMOÇÃO DO CATETER CENTRAL DE INSERÇÃO PERIFÉRICA EM NEONATOS}

Dissertação apresentada à Escola de Enfermagem da Universidade de São Paulo para obtenção do título de Mestre na área de concentração Enfermagem Obstétrica e Neonatal

Orientadora

Profa. Dra. Amélia Fumiko Kimura 


\section{Catalogação na Publicação (CIP) \\ Biblioteca "Wanda de Aguiar Horta" Escola de Enfermagem da Universidade}

\section{Camargo, Patrícia Ponce de.}

Procedimento de inserção, manutenção e remoção do cateter central de inserção periférica em neonatos. / Patrícia Ponce de Camargo. - São Paulo, 2007. $164 \mathrm{p}$.

Dissertação (Mestrado) - Escola de Enfermagem da Universidade de São Paulo.

Orientadora: Prof ${ }^{a}$ Dr $^{\mathrm{a}}$ Amélia Fumiko Kimura.

1. Recém-nascido 2. Cateterismo 3. Unidades de terapia intensiva 4. Veia cava I. Título. 
DEDICATÓRIA 
A meus pais, Moisés e Derci, com dedicação e amor não mediram esforços para realizar meus sonhos profissionais, sempre me encorajando nos momentos difíceis;

A meu irmão Fernando, com quem sempre dividi minhas alegrias, expectativas, anseios e medos e com sua paciência sempre esteve disposto a ajudar na realização de meus sonhos;

A minha cunhada Mara, que passei a confiar como uma irmã, pois sempre procurou acompanhar minha trajetória profissional e pessoal, intercedendo em suas orações por mim;

Aos recém-nascidos que sempre foram minha inspiração de vida e ensinaram-me a ser uma pessoa melhor. 
AGRADECIMENTOS 
À Profa. Dra. Amélia Fumiko Kimura que, nos momentos mais decisivos, soube me acolher, ensinar, incentivar e, sobretudo, ser amiga nas horas que mais precisei, motivando meu crescimento profissional e pessoal;

Às Professoras Doutoras Edi Toma, Maria Alice Tsunechiro e Josefa Gardeñas Borrell, pelo incentivo oferecido a meu trabalho e pelas valiosas sugestões e contribuições realizadas no Exame de Qualificação;

À fisioterapeuta Carla Marques Nicolau, que soube dividir comigo seus conhecimentos e contribuiu intensamente no desenvolvimento deste estudo;

À enfermeira Carla Heleno Mollaco, pelas palavras de incentivo e experiências compartilhadas, estando sempre a meu lado nos momentos mais difíceis;

À enfermeira Aline Santiago Rosa Dantas, pelos momentos de descontração e alegria compartilhada;

À enfermeira Eliane Regina Coelho Berti, por toda a contribuição para realização desta pesquisa;

Às enfermeiras Leontina, Sonia, Vera, Renata, Maria de Jesus, Vanessa, Andréia, Débora, Neusa, Cida Pereto, Solange, Alessandra pelo envolvimento em todas as fases deste estudo;

Às auxiliares de enfermagem, pela disposição, companheirismo, amizade durante a coleta de dados deste trabalho;

Aos médicos, pelas contribuições na trajetória e realização desta pesquisa;

À Professora Ivone Borelli, pela atenciosa revisão de língua portuguesa; 
À Enfermeira Camilla Alexsandra Scneck, pelas sugestões no desenvolvimento deste estudo;

Às minhas queridas tias Anita e Daisy, pelo carinho, preocupação, incentivo e apoio. 


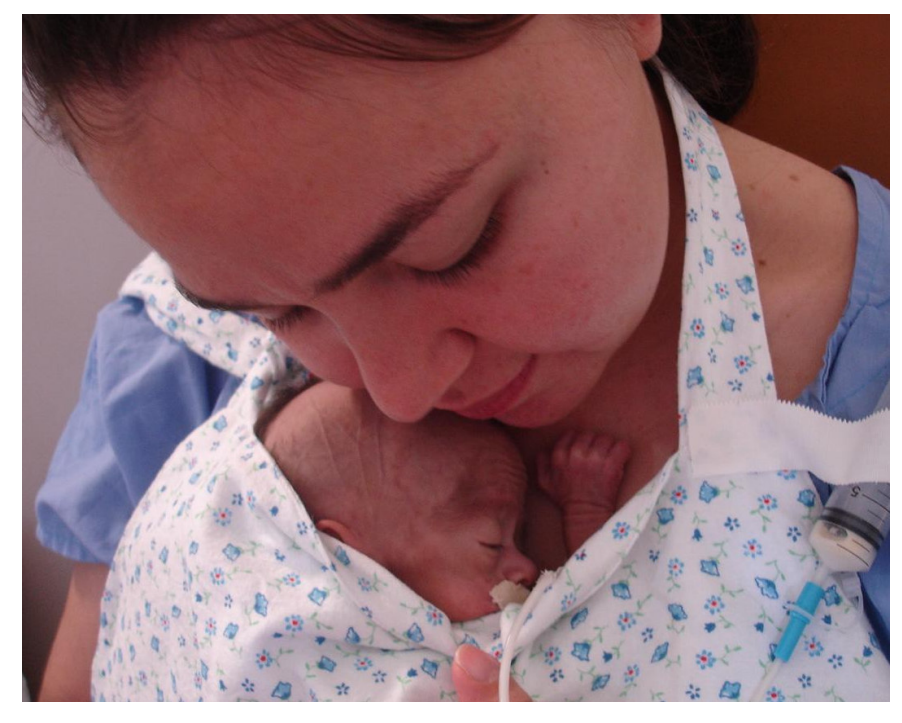

"O poder, o sucesso e a felicidade, do modo como o mundo os conhece, serão daqueles que se esforçarem muito para consegui-los, mas a paz, o amor e a alegria vêm apenas de Deus" 
Camargo PP. Procedimento de inserção, manutenção e remoção do cateter central de inserção periférica em neonatos. [dissertação]. São Paulo: Escola de Enfermagem da Universidade de São Paulo; 2007.

\section{RESUMO}

O cateter central de inserção periférica (PICC) é um dispositivo cada vez mais utilizado nas Unidades de Terapia Intensiva Neonatal (UTIN). O objetivo do estudo foi caracterizar os neonatos (RN) submetidos ao procedimento de inserção do cateter PICC e descrever suas práticas de inserção, manutenção e remoção em RN. Estudo observacional com delineamento longitudinal realizado no Berçário Anexo à Maternidade do Hospital das Clínicas da Faculdade de Medicina da Universidade de São Paulo. Os dados foram obtidos pela observação dos procedimentos e informações registradas nos prontuários dos neonatos submetidos ao procedimento. No estudo, incluíram-se todos os procedimentos de inserção, manutenção e remoção de cateter PICC ocorridos entre de março e setembro de 2006, em recém-nascidos internados na unidade neonatal citada. Antes do início da coleta dos dados, o projeto de pesquisa foi apreciado e aprovado pelo Comitê de Ética em Pesquisa da Instituição, campo do estudo. No período estudado, ocorreram 37 procedimentos de inserção do cateter PICC. A média da idade gestacional e o peso dos RN eram de 32,2 semanas e 1.289,2 gramas, respectivamente. A maioria, 22 $(59,4 \%) \mathrm{RN}$, era do sexo masculino, $18(48,7 \%) \mathrm{RN}$ tinham menos de três dias de vida no dia do procedimento e $35(94,6 \%)$ RN foram submetidos à inserção do cateter para infundir nutrição parenteral total. A maioria, 21 $(56,8 \%)$ RN, apresentou diagnóstico de síndrome do desconforto respiratório. A administração de fármaco sedativo previamente ao procedimento ocorreu em $4(10,8 \%)$, nenhum RN recebeu analgesia. O tipo de cateter mais utilizado foi o de poliuretano, $35(94,6 \%)$. A média da freqüência de punções venosas foi 3,4 e em $8(21,6 \%)$ RN foram obtidos sucesso na introdução do cateter na primeira punção venosa. As veias mais puncionadas foram as localizadas em membros superiores, a basílica foi puncionada em $29,9 \%$ dos RN e a cefálica, em $22,8 \%$ dos RN. Fragilidade vascular, transfixação venosa e obstrução do cateter foram os principais motivos de insucesso na inserção do PICC. Alteração da viscosidade sangüínea foi uma intercorrência identificada pelas enfermeiras na inserção do PICC. A prevalência de sucesso do procedimento foi de $64,9 \%$ (24 RN). Obteve-se posicionamento central da ponta do cateter em $20(83,3 \%) \mathrm{RN} \mathrm{e}$ periférico em $4(16,7 \%) \mathrm{RN}$. A média da extensão do cateter introduzido em MSD foi de $11,4 \mathrm{~cm}$, em MSE, $13,5 \mathrm{~cm}$ e em região cervical, $7,1 \mathrm{~cm}$. Solução de clorexidina a $0,5 \%$ foi o anti-séptico mais utilizado nos curativos e a NPT foi a solução mais infundida pelo cateter. O tempo médio de permanência do cateter foi 8,9 dias, $11(27,5 \%)$ foram removidos em decorrência de infecção do cateter, $7(17,5 \%)$ pelo término da terapia intravenosa e $7(17,5 \%)$ por obstrução. Dos 24 cateteres removidos, $14(58,3 \%)$ foram enviados para cultura, dos quais, $10(71,4 \%)$ tiveram resultado negativo. Das quatro pontas com resultado positivo, em duas (14,3\%) foram identificados Estafilococos coagulase negativa. 
Descritores: Recém-nascido, cateter central de inserção periférica, acesso venoso central. 
Camargo PP. Insertion, maintenance and removal procedures of peripherally inserted central catheters (PICC) in neonates. [thesis]. São Paulo: University of São Paulo Nursing School; 2007.

\begin{abstract}
The peripherally inserted central catheter (PICC) is increasingly employed in the neonatal intensive care units. The aims of the study were to characterize the neonates who underwent PICC catheter insertion and to describe insert, upkeep and removal PICC catheter practices in neonates. Prospective cohort study carried out at Neonatal Intensive Care Unit of University of São Paulo School Medical Hospital. Data were obtained by nurse procedures performance observation and from the medical chart records of the neonates who underwent PICC catheter insertion. Data were collected from March to September, 2006 and all the neonates underwent PICC catheter insertion during this period were included in the study. The study protocol was approved by the Research Ethics Board of the Hospital where the study was carried out. Written informed consents were obtained from parents or legal guardian of all infant newborns underwent PICC catheter insertion and from certified registered nurses responsible for catheter insertion, maintenance of the line and for removal it. It was obtained data from 32 infants newborn underwent procedure of PICC catheter insertion. The gestacional age and infant weight mean were, 32.2 weeks and $1289.2 \mathrm{~g}$, respectively; $22(59.4 \%)$ neonates were male, the PICC catheter was inserted in 18 (48.7\%) neonates in the first three days of life and $35(94.6 \%)$ babies were underwent PICC insertion to provide total parenteral nutrition; 21 (56.8\%) neonates had diagnosis of respiratory distress syndrome, any of them received analgesics and $4(10,8 \%)$ newborns received sedation. The polyurethane catheter was more used, $35(94,6 \%)$ than the silicone catheter, $2(5,4 \%)$. The mean of venous puncture frequency was of 3.4 and the rate success obtained in the first attempt was 21,6\% (8 newborn). The most accessed veins for insertion PICC lines were basilic, $29,9 \%$ and cephalic, 22,8\%. Vascular fragility, venous transfixation and obstruction were the majorities causes of failure to insert the PICC line. The frequency of success on PICC line insertion was $64,9 \%$ (24 neonates). The position of tip catheter in 83,3\% (20 neonates) was central (superior vena cava), others $16,7 \%$ (4 neonates) tips were peripherally. The length of catheter line mean to thread in right arm veins was $11,4 \mathrm{~cm}$, in the left arm, $13,5 \mathrm{~cm}$ and in the jugular vein was $7,1 \mathrm{~cm}$. It was used chlorhexidine $0.5 \%$ antiseptic solution in the majority of catheter insertion site dressing. Total parenteral nutrion was the soluction infused by the catheter line. The mean time of remaining the catheter was 8.9 days, $11(27,5 \%)$ catheters were withdrawn due to suspect of catheter infection, $7(17,5 \%)$ catheters withdrawn after end the intravenous therapy and 7 $(17,5 \%)$ due to obstruction. From 24 catheters withdrawn, $14(58,3 \%)$ tip catheters were underwent to microbyological analysis and the results were negative for $10(71,4 \%)$ analysis, from others four tips catheter which results were positive, in two (14,3\%) identified coagulase-negative staphylococci.
\end{abstract}


Key words: Infant-newborn, peripherally inserted central catheter, central venous access. 


\section{LISTA DE TABELAS}

Tabela 1 Caracterização dos recém-nascidos submetidos ao procedimento de inserção do PICC. Berçário Anexo à Maternidade do HCFMUSP. São Paulo, $2006(\mathrm{~N}=37)$

Tabela 2 Medidas descritivas das cariáveis de caracterização dos recémnascidos submetidos à implantação do PICC. Berçário Anexo à maternidade do HCFMUSP. São Paulo, 2006. $(\mathrm{N}=37)$.

Tabela 3 Resultado da hemocultura antes da inserção do PICC. Berçário Anexo à Maternidade do HCFMUSP. São Paulo, 2006. (N=37)

Tabela 4 Resultado do exame Proteína C Reativa de recém-nascidos com hemocultura positiva antes da inserção do cateter PICC. Berçário Anexo à Maternidade do HCFMUSP. São Paulo, 2006. (N=37)

Tabela 5 Resultado do hematócrito antes da inserção do PICC. Berçário Anexo à Maternidade do HCFMUSP. São Paulo, 2006 68

Tabela 6 Uso de fármaco sedativo pré-inserção do cateter PICC. Berçário Anexo à Maternidade do HCFMUSP. São Paulo, 2006

Tabela 7 Tipo de cateter PICC utilizado. Berçário Anexo à Maternidade do HCFMUSP. São Paulo, 2006

Tabela 8 Medidas descritivas da freqüência de punções venosas na inserção do PICC. Berçário Anexo à Maternidade do HCFMUSP. São Paulo, 2006. $(\mathrm{N}=37)$

Tabela 9 Freqüência de sucesso na inserção do PICC, segundo ordem seqüencial das punções venosas realizadas. Berçário Anexo à Maternidade do HCFMUSP. São Paulo, 2006. (N=37) 
Tabela 10 Medidas descritivas da freqüência cardíaca pré e pós-punção. Berçário Anexo à Maternidade do HCFMUSP. São Paulo, 2006

Tabela 11 Medidas descritivas dos valores de saturação de oxigênio pré e pós-punção. Berçário Anexo à Maternidade do HCFMUSP. São Paulo, 2006

Tabela 12 Segmento corporal e veia puncionada para inserir o PICC, segundo a ordem seqüencial das punções. Berçário Anexo à Maternidade do HCFMUSP. São Paulo, 2006. ( $N=127)$ 72

Tabela 13 Veias puncionadas para inserir o PICC. Berçário Anexo à Maternidade do HCFMUSP. São Paulo, 2006 73

Tabela 14 Motivos de insucesso nas primeiras quatro punções venosas para inserção do PICC. Berçário Anexo à Maternidade do HCFMUSP. São Paulo, 2006

Tabela 15 Motivos de insucesso da quinta a oitava punção venosa para inserção do PICC. Berçário Anexo à Maternidade do HCFMUSP São Paulo, 2006

Tabela 16 Intercorrências na inserção do PICC observadas nas quatro primeiras punções do PICC. Berçário Anexo à Maternidade do HCFMUSP. São Paulo, 2006

Tabela 17 Motivos de intercorrências da quinta e sétima punções venosa no procedimento de inserção do PICC. Berçário Anexo à Maternidade do HCFMUSP. São Paulo, 2006

Tabela 18 Sucesso obtido na introdução do cateter PICC entre os recémnascidos submetidos ao procedimento. Berçário Anexo à Maternidade do HCFMUSP. São Paulo, 2006. ( $N=37)$ 
Tabela 19 Local alojada pela ponta do cateter PICC pós-inserção visualizada pelos exames de radiografia de tórax. Berçário Anexo à Maternidade do HCFMUSP. São Paulo, 2006. (N=27) ....77

Tabela 20 Distribuição dos recém-nascidos submetidos à tração do cateter PICC para reposicionamento da ponta. Berçário Anexo à Maternidade do HCFMUSP. São Paulo, 2006. ( $N=24)$

Tabela 21 Local alojada pela ponta do cateter PICC, após manobra de tração. Berçário Anexo à Maternidade do HCFMUSP. São Paulo, 2006. $(\mathrm{N}=13)$

Tabela 22 Posicionamento da ponta do cateter PICC no momento de fixação Berçário Anexo à Maternidade do HCFMUSP. São Paulo, 2006. $(\mathrm{N}=24)$

Tabela 23 Medidas descritivas do comprimento $(\mathrm{cm})$ do cateter introduzido, segundo o segmento puncionada. Berçário Anexo à Maternidade do HCFMUSP. São Paulo, 2006. ( $\mathrm{N}=24)$

Tabela 24 Realização de exame ecocardiográfico pós-inserção do cateter. Berçário Anexo à Maternidade do HCFMUSP. São Paulo, 2006. $(\mathrm{N}=24)$

Tabela 25 Posicionamento da ponta do cateter PICC visualizado pelo ecocardiograma. Berçário Anexo à Maternidade do HCFMUSP. São Paulo, 2006. (N=8)

Tabela 26 Medidas descritivas do tempo (em minutos) entre a inserção do PICC e o primeiro exame de radiografia de tórax e tração do cateter até a segunda radiografia. Berçário Anexo à Maternidade do HCFMUSP. São Paulo, 2006 
Tabela 27 Solução infundida pelo PICC imediatamente após a fixação do cateter. Berçário Anexo à Maternidade do HCFMUSP. São Paulo, 2006. $(\mathrm{N}=24)$

Tabela 28 Variáveis relacionadas ao curativo realizado no cateter PICC. Berçário Anexo à Maternidade do HCFMUSP. São Paulo, 2006. $(\mathrm{N}=24)$

Tabela 29 Intercorrências observadas na realização de curativos nos cateteres PICC. Berçário Anexo à Maternidade do HCFMUSP. São Paulo, 2006.

Tabela 30 Medidas descritivas do tempo de permanência em dias do cateter PICC nos recém-nascidos. Berçário Anexo à Maternidade do HCFMUSP. São Paulo, 2006

Tabela 31 Indicação de remoção do cateter PICC. Berçário Anexo à Maternidade do HCFMUSP. São Paulo, 2006. ( $N=24)$ 84

Tabela 32 Envio da ponta do cateter PICC para cultura. Berçário Anexo à Maternidade do HCFMUSP. São Paulo, 2006 .85

Tabela 33 Resultado da cultura de ponta do cateter PICC. Berçário Anexo à Maternidade do HCFMUSP. São Paulo, 2006 85

Tabela 34 Microrganismo identificados na cultura de ponta de cateter. Berçário Anexo à Maternidade do HCFMUSP. São Paulo, 2006. $(\mathrm{N}=4)$ 


\section{SUMÁRIO}

Lista de Tabelas

Resumo

Abstract

1 Introdução

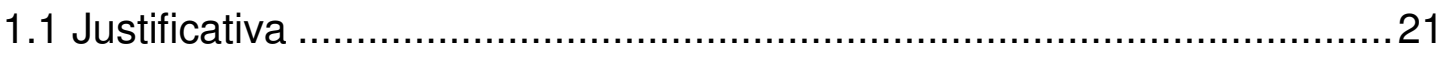

1.2 Revisão da Literatura ..............................................................23

1.2.1 O contexto histórico do uso do PICC na assistência neonatal..............23

1.2.2 Descrição do dispositivo PICC ........................................................23

1.2.3 Anatomia a fisiologia relacionadas à prática de inserção do PICC .......25

1.2.4 Locais de inserção do PICC em recém-nascidos ...........................27

1.2.5 Principais vantagens e desvantagens do PICC em recém-nascidos ....28

1.2.6 Principais indicações e contra-indicações na inserção do cateter PICC em recém-nascidos..............................................................29

1.2.7 Orientações aos pais sobre o cateter PICC ...................................30

1.2.8 Capacitação técnica do enfermeiro para a inserção do cateter PICC...31

1.2.9 Técnica de inserção do cateter PICC..............................................32

1.2.10 Alívio da dor na inserção do cateter PICC ....................................34

1.2.11 Manutenção diária dos cuidados com o cateter PICC ........................35

1.2.12 Remoção do cateter PICC nos recém-nascidos .............................37

1.2.13 Principais complicações do cateter PICC nos recém-nascidos ..........38

1.2.13A Complicações relacionadas à inserção do cateter ..........................38

1.2.13B Complicações relacionadas à pós-inserção do cateter.....................39

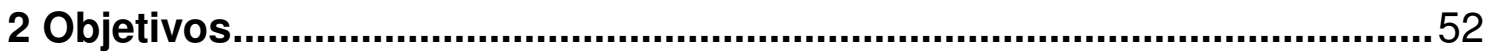

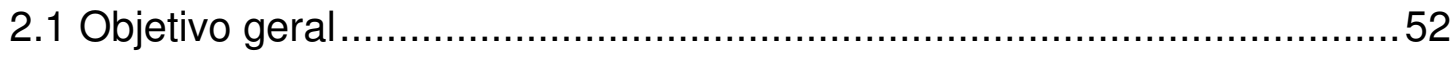

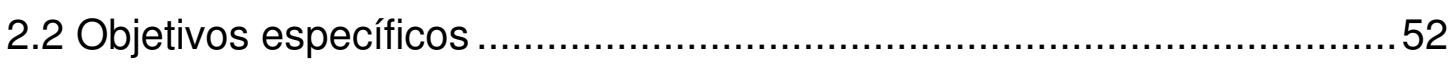

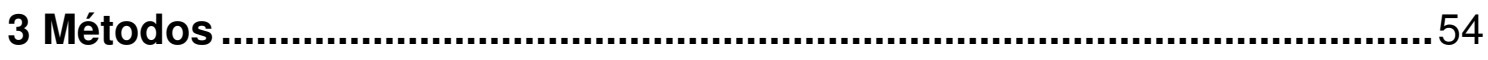

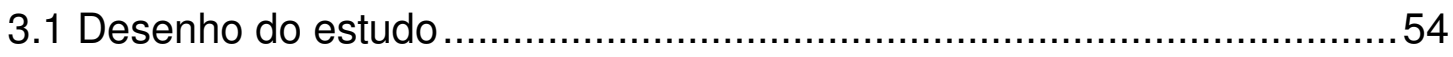

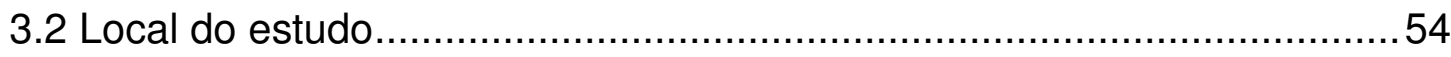

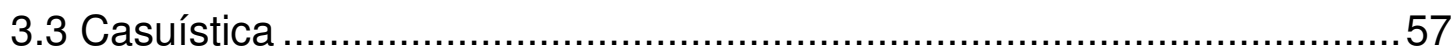




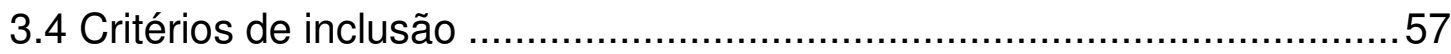

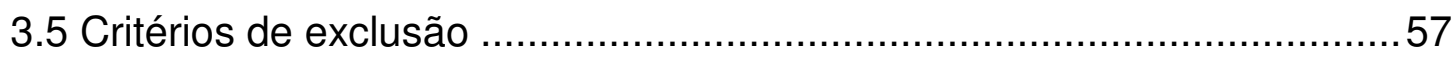

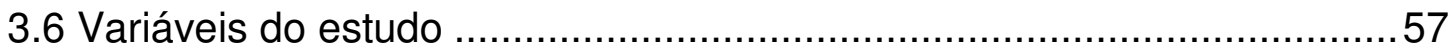

3.6.1 Variáveis de caracterização dos recém-nascidos submetidos ao procedimento de inserção do cateter PICC ......................................58

3.6.2 Dados relacionados à inserção, manutenção e remoção do cateter

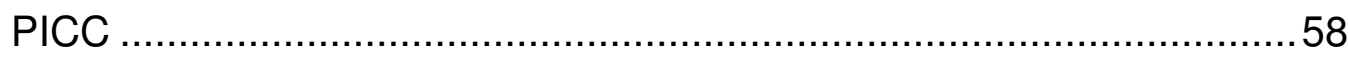

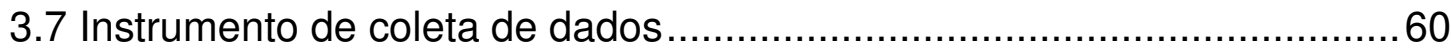

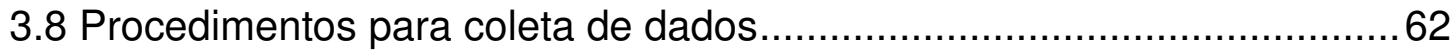

3.9 Organização, tratamento e análise dos dados .....................................62

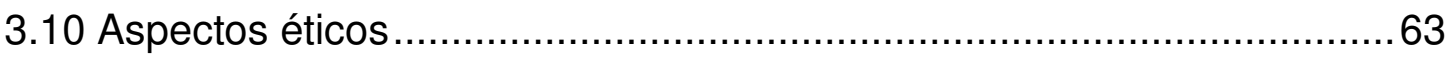

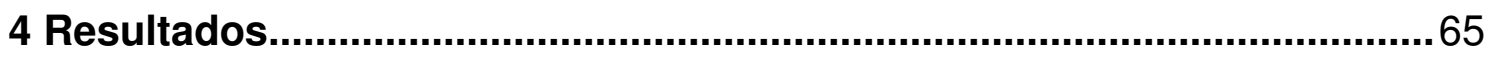

4.1 Caracterização dos recém-nascidos submetidos ao procedimento de

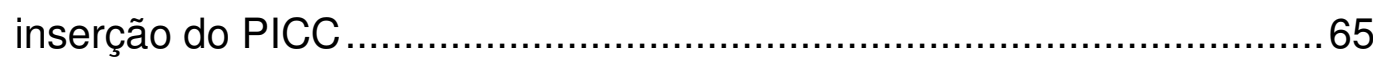

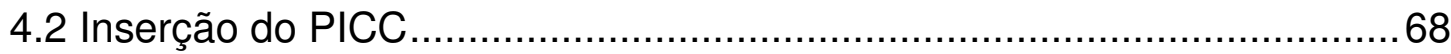

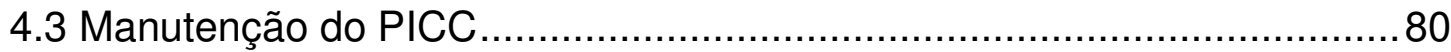

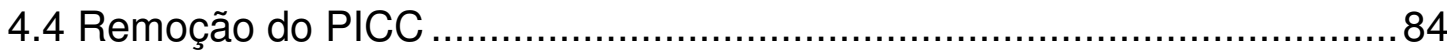

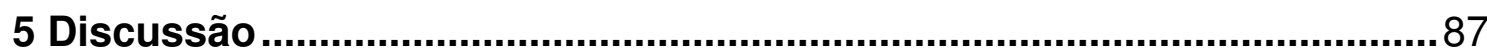

5.1 Caracterização dos recém-nascidos submetidos ao procedimento de

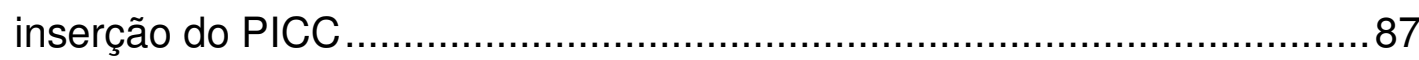

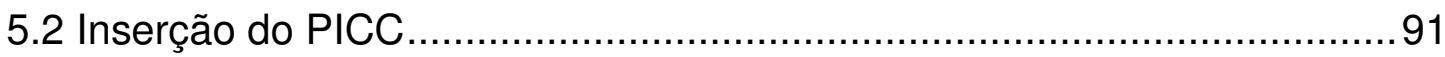

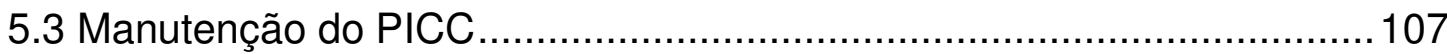

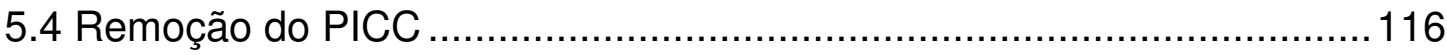

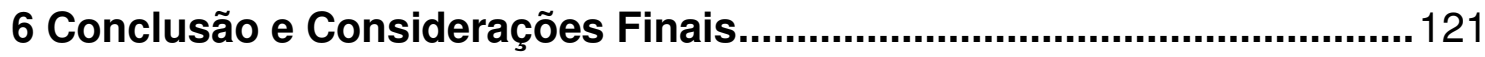

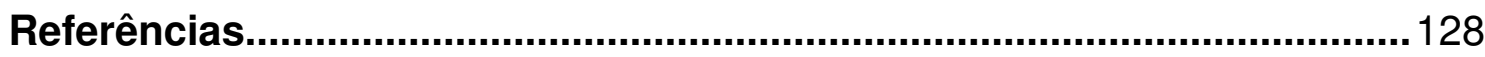

Anexos

Anexo I Modelo para elaboração de protocolo cateter PICC ....................141

Anexo II Formulário de coleta de dados .................................................. 143

Anexo III Termo de Consentimento Livre Esclarecido do responsável pelo recém-nascido....................................................................160

Anexo IV Termo de Consentimento Livre Esclarecido do enfermeiro .............163

Anexo V Carta de aprovação pelo Comitê de Ética .................................... 164 
INTRODUCÃO 


\section{INTRODUÇÃO}

\subsection{Justificativa do estudo}

A utilização do Cateter Central de Inserção Periférica (PICC) tem se tornado um componente essencial na terapia intravenosa em recémnascidos criticamente doentes.

O cateter PICC é um dispositivo intravenoso que permite a infusão de soluções hiperosmolares com pH não fisiológico, drogas parenteral vesicantes ou irritantes e nutrição parenteral prolongada (Camara, 2001).

No Brasil, o procedimento de implantação do cateter PICC é regulamentado pelo Conselho Federal de Enfermagem, Resolução ํo. 258/2001, artigos $1^{\circ}$ e $2^{\circ}$ ao definir que 0 enfermeiro para realizar tal procedimento, deverá qualificar-se (Brasil, 2000).

Cabe, então, ao enfermeiro a atribuição de inserir, manipular e remover o cateter PICC, quando este for indicado.

A qualificação e/ou capacitação para realizar o procedimento é adquirida por meio de cursos oferecidos pelas sociedades de enfermagem, segundo diretrizes determinadas pela Infusion Nurses Society (INS) e pelo Center for Diseases Control and Prevention (CDC), órgãos sediados nos Estados Unidos da América (CDC, 2002; SOBETI, 2004).

Atualmente, no Brasil à Sociedade Brasileira de Especialistas em Pediatria (SOBEP) e a Sociedade Brasileira de Enfermeiros em Terapia Intensiva (SOBETI) oferecem cursos de capacitação do procedimento de implantação do cateter PICC.

O cateter central de inserção periférica tornou-se vantajoso para o neonato prematuro, porque permite reduzir a freqüência de punções venosas e, conseqüentemente, minimizar procedimentos invasivos, exposição dos recém-nascidos à dor e estresse, além de ser a melhor via para administração da Parenteral Total (NPT), prescrita com freqüência aos pré-termos de muito baixo peso, dentre outras vantagens. 
A inserção do cateter PICC não é um procedimento isento de complicações, assim, avaliar as práticas que envolvem a realização desse procedimento é necessário para garantir a qualidade da assistência visando a reduzir a morbidade e mortalidade neonatal em decorrência de complicações inerentes ao uso do cateter PICC.

Como enfermeira assistencial de uma Unidade de Terapia Intensiva Neonatal de um Hospital-Escola, o procedimento de implantação do cateter PICC é uma atribuição da enfermeira e o procedimento é exclusivamente realizado por profissionais que tenham realizado o curso de capacitação oferecido pela SOBEP ou SOBETI.

$\mathrm{Na}$ unidade neonatal, onde atuo o uso do cateter PICC foi introduzido em 1997, desde então as enfermeiras foram se qualificando e, atualmente, são cinco profissionais capacitadas nesse procedimento.

Considerando que o cuidado com o cateter PICC requer uma avaliação contínua, pelos riscos a que ficam expostos os recém-nascidos submetidos ao uso desse dispositivo, é preciso que o serviço elabore e institua um protocolo de atendimento, padronizando as etapas do procedimento e seu manejo adequado frente a intercorrências detectadas, visando a garantir a qualidade do atendimento prestado.

$\mathrm{Na}$ instituição do estudo, o protocolo adotado foi desenvolvido pela SOBETI (Anexo I). Entretanto, é relevante que cada serviço elabore seu próprio protocolo, levando em consideração as características da população de recém-nascidos atendidos e os recursos humanos e materiais disponíveis na instituição. Para a elaboração do protocolo, em primeira instância, é preciso caracterizar o perfil dos pacientes atendidos e as demandas por cuidado no que se referem ao uso do cateter PICC.

Desde que o procedimento de implantação do cateter PICC passou a ser adotado em nosso serviço, como uma atribuição da enfermeira, não foi realizado um levantamento de caracterização das práticas adotadas pelas enfermeiras em sua inserção, manutenção e remoção. Considero oportuno 
realizar esta caracterização do processo de implantação do cateter PICC, a fim de conhecer o atual estado dessa prática assistencial e com isso obter subsídios para avaliar a qualidade do cuidado, propor adoção de condutas que impliquem reduzir o tempo de internação dos recém-nascidos e contribuir para redução da taxa de morbidade e mortalidade neonatal.

\subsection{Revisão da Literatura}

\subsubsection{O contexto histórico do uso do PICC na assistência neonatal}

A terapia intravenosa iniciou-se no Renascimento com a descoberta da circulação sangüínea, da agulha hipodérmica e da primeira transfusão sangüínea (Phillips, 2001).

Em 1929, descobriu-se que um vaso central poderia ser atingido por um acesso periférico, sem causar danos à veia. Através da introdução de um tubo de borracha em uma veia periférica era possível atingir um grande vaso, como a veia cava superior. A eficácia do procedimento foi comprovada na década de 50 , século $\mathrm{XIX}$, quando se observou que as drogas que atingiam os grandes vasos, tornavam-se mais diluídas, diminuindo, os riscos de reações inflamatórias e trombose química (Silva e Nogueira, 2004).

Pela primeira vez, o procedimento de implantação do PICC foi realizado para infusão de nutrição parenteral em Unidade de Terapia Intensiva Neonatal em 1970 (Schwengel, McGready, Berenholtz, Kozlowski, Nichols, Yaster, 2004).

A partir de 1980, a inserção do PICC popularizou-se com o crescimento das pesquisas nesse campo (Geddes e Nichols, 2005).

No Brasil, só no final da década de 90 do século $\mathrm{XX}$, este procedimento foi introduzido, passando a ser parte do cuidado de pacientes (Pezzi, 2004).

\subsubsection{Descrição do dispositivo PICC}

O cateter central de inserção periférica (PICC) é um dispositivo intravenoso, inserido em veias de regiões periféricas e progride por meio de uma agulha introdutora, até a porção final da veia cava, adquirindo 
características de cateter central (Camara, 2001; Racadio, Doellman, Johnson, Bean, Jacobs, 2001).

O PICC é um cateter longo de 20 a 60 centímetros de comprimento e varia de 1 a 5 French ( $F r)$ de calibre, tendo um a dois lúmens (Camara, 2001).

Atualmente, os cateteres disponíveis no mercado são produzidos com dois tipos de materiais biocompatíveis: silicone e poliuretano.

O silicone é considerado um polímero de elastômero com estabilidade prolongada e resistência a variações de temperatura. É macio, flexível e bastante resistente a dobras (Becton Dickinson, 2000). Possui paredes mais grossas, que suportam menos pressões com maiores chances de rompimento ou perfuração, tromboresistente e reduzida aderência bacteriana (SOBETI, 2004).

O poliuretano faz parte uma ampla cadeia de polímeros chamados termoplásticos. O cateter PICC de poliuretano é mais resistente, menos maleável, suporta maiores pressões, possibilita um fluxo maior de soluções e menores riscos de rompimento (Becton Dickinson, 2000).

Atualmente, não existe um material com propriedades de inserção e permanência ideais, devendo, então, pesar as vantagens e desvantagens de ambos, antes de se optar por um deles.

$\mathrm{Na}$ utilização do cateter PICC, o sucesso aumenta com o conhecimento sobre as propriedades dos cateteres e com a devida habilitação do profissional responsável pela inserção, manutenção e remoção do dispositivo.

O PICC é disponibilizado comercialmente em duas formas de apresentação:

Material completo: campos cirúrgicos, torniquetes, fita métrica, soluções anti-sépticas, agulha introdutória, tesoura, seringas, pinça auxiliar para inserção, gazes, adesivos transparentes e o cateter.

Material Básico: fita métrica, agulha introdutória e o cateter. 


\subsubsection{Anatomia a fisiologia relacionadas à prática de inserção do PICC}

Segundo Phillips (2001) para realizar com eficácia uma terapia intravenosa, o enfermeiro precisa ter domínio do conhecimento da anatomia e da fisiologia da pele e do sistema vascular, além de estar familiarizado com a resposta fisiológica do sistema vascular quanto ao calor, frio e estresse. É importante, também, tornar-se familiarizado com a espessura e a consistência da pele de vários locais.

A pele é constituída de duas camadas principais: a epiderme e derme. A epiderme é a camada mais externa da pele, é composta por uma camada córnea, granular, de células espinhosas e uma camada basal, das camadas da pele esta é a que mais sofre modificações em sua estrutura normal. As modificações podem ser decorrentes de interferências externas, propiciando maior vulnerabilidade em sua função de defesa, acarretando maior enrijecimento e, conseqüentemente, dificuldades de punção. A epiderme é a camada sobre a qual, em situações normais, há depósito de bactérias, que se denominam flora residente (SOBETI, 2004).

A derme está localizada abaixo da epiderme, é formada do tecido conjuntivo, que dá suporte aos vasos, nervos, gânglios linfáticos e folículos pilosos. É sensível e vascularizada, reagindo aos estímulos dolorosos, alterações de temperatura e sensação de pressão (Phillips, 2001; SOBETI 2004).

Existem cinco tipos de receptores sensoriais, quatro deles envolvidos na terapia intravenosa: os mecanorreceptores que processam as sensações táteis da pele; os termorreceptores que processam frio, calor e dor; os nociceptores que processam a dor e os quimiorreceptores que processam as trocas osmóticas no sangue, diminuindo a pressão arterial (Phillips, 2001).

O sistema circulatório subdivide-se em circulação pulmonar e sistêmica. A circulação sistêmica, em particular, as veias periféricas são as utilizadas na terapia intravenosa, funcionam similarmente às artérias, porém 
são mais finas e têm menos tecido muscular, podendo ser distendidas com facilidade e suportam grandes volumes de sangue sob baixa pressão. Aproximadamente, $75 \%$ do volume total de sangue estão contidos nas veias (Phillips, 2001).

Algumas veias possuem válvulas, sobretudo as que transportam sangue contra a gravidade, como nas extremidades mais inferiores. As válvulas são compostas de dobras endoteliais e ajudam a prevenir o refluxo distal do sangue. Estão localizadas nos pontos de ramificação, produzindo uma notável saliência nos vasos (Phillips, 2001).

As veias compõem-se de três camadas associadas com diversas características importantes para o fluxo venoso.

A túnica íntima é a camada mais interna e, portanto, está em contato direto com o fluxo venoso. Permite, facilmente, a passagem de sangue pelos vasos. Qualquer rugosidade nesse leito durante a punção venosa ou enquanto o cateter estiver no local, poderá criar um processo de formação de trombose. Essa rugosidade pode ser provocada por dispositivos de acesso venoso rígido ou excessivamente calibroso, hiperosmolaridade da infusão, etc (Phillips, 2001; SOBETI, 2004).

A túnica média é a camada composta de tecido muscular e elástico, contém as fibras nervosas responsáveis pela vasoconstrição e vasodilatação. Esta camada possibilita às veias tolerar mudanças na pressão e fluxo, proporcionando recuo elástico e contração muscular, que podem variar o calibre venoso (Phillips, 2001; SOBETI 2004).

A túnica adventícia, camada mais externa, é composta por fibras elásticas longitudinais e tecido conjuntivo que contorna e sustenta a veia. Algumas vezes, durante a punção venosa, pode-se sentir um "estalo", assim que se perfura a túnica adventícia (Phillips, 2001).

Durante a punção venosa, se a ponta do cateter perfurar a túnica adventícia ou for inserida na camada da túnica média, uma pequena quantidade de sangue retornará no cateter; entretanto, este não progredirá porque ficará preso entre as camadas (Phillips, 2001). 


\subsubsection{Locais de inserção do PICC em recém-nascidos}

A escolha da veia deve ser analisada pelas suas características, sendo necessário observar se são palpáveis, calibrosas e com menos curvaturas.

A pele sobrejacente à veia de escolha deve estar íntegra, sem hematomas, edemas, sinais de infecção ou alterações anatômicas. A inserção do cateter PICC deve considerar estas características, a fim de obter sucesso em sua introdução e permanência (Pettit, 2002).

Conforme Phillips (2001); SOBETI (2004); Silva e Nogueira (2004), a veia basílica nasce no lado medial do arco venoso dorsal, seu diâmetro mede 0,6 a $0,8 \mathrm{~mm}$ e o comprimento aproximado é de 24 centímetros. $\mathrm{Na}$ primeira punção venosa é a veia preferencial. A veia cefálica nasce no lado radial do arco venoso, tem 0,4 a $0,6 \mathrm{~mm}$ de diâmetro, comprimento aproximado de 38 centímetros. A veia cubital é uma anastomose oblíqua, altamente variável, entre as veias basílica e cefálica, e a veia axilar forma-se na união das veias basílica e braquial e sua continuação constitui a veia subclávia, com 1,0 a $1,6 \mathrm{~cm}$ de diâmetro e quase 13 centímetros.

Conforme os autores citados, a veia dos arcos dorsais está localizada no dorso da mão pela união das veias entre as articulações. Nos membros inferiores, as veias de acesso para inserção do PICC são a poplítea, a safena e a femural. Em função da estrutura anatômica dessas veias, a inserção do cateter PICC não é recomendada nelas, em razão das válvulas venosas que facilitam o retorno venoso, porém são obstáculos para a progressão do cateter. A veia poplítea é a mais visível nos prematuros, pela sua proximidade com a artéria poplítea deve ser puncionada com cautela. A veia safena localiza-se na região mediana da perna, tem sete a 15 válvulas. Pelo excesso de válvulas, a passagem do cateter PICC apresenta maior dificuldade técnica, favorecendo o desenvolvimento de edema dos membros 
inferiores. A veia femural localiza-se abaixo do ligamento inguinal é pouco visível, de difícil punção, o que dificulta a inserção do PICC.

As veias localizadas na região temporal, auricular posterior e jugular externa do segmento cefálico devem ser as últimas opções de inserção do PICC pela dificuldade de fixação e maior risco de migração do cateter. A veia temporal é considerada pouco segura para se inserir e manter o PICC, porque se localiza adjacente à artéria temporal e a veia auricular posterior é de tamanho variável e frágil. A veia jugular externa é a mais visível, com maiores riscos de infecção pelo local. Recomenda-se puncionar a jugular externa direita, pois a jugular externa esquerda pode ascender para a jugular interna ao invés de progredir para a veia cava (Phillips, 2001; SOBETI, 2004; Silva e Nogueira, 2004).

O cateter PICC é considerado em posição central, quando sua ponta estiver na porção final da veia cava superior ou porção inicial da veia cava inferior. Em membros superiores, cabeça e pescoço, a distância entre o local de punção até a clavícula e terceiro espaço intercostal são medidos. Para a punção em membros inferiores, mede-se o comprimento entre a região da punção passando pela região inguinal até a umbilical, finalizando na região do apêndice xifóide (Becton Dickinson, 2000).

NAVAN (1996) cita que a ponta do cateter localizada na veia axilar proximal, subclávia ou inominada é denominada de Midclavicular. A ponta do cateter na porção proximal da extremidade superior é chamada Midline, tanto a Midclavicular como a Midline são classificadas, como inserções periféricas, fora da veia cava superior.

\subsubsection{Principais vantagens e desvantagens do PICC em recém- nascidos}

Conforme Silva e Nogueira (2004), as vantagens do PICC são: confiabilidade de acesso; inserção menos traumática; menor risco de ocorrer flebite química, extravasamento e infiltração de líquidos; possibilidade de administração de medicamentos irritantes e/ou vesicantes; disponibilidade 
de vários acessos venosos para seleção e implantação e diminuição do estresse causado pelas múltiplas punções venosas.

Segundo Chlebicki e Teo (2003) outras vantagens do cateter PICC são: redução de custo; facilidade de inserção no recém-nascido mantido na incubadora; melhor evolução clínica; menor risco de acidentes na implantação; menor risco de contaminação e maior tempo de permanência; conservação do sistema venoso periférico nas extremidades superiores; menor risco de infecção em relação a outros dispositivos vasculares centrais; diminuição da hipoxemia e hipotermia e menor restrição da mobilidade, entre outras.

As desvantagens estão relacionadas ao tipo de material e características do cateter. $\mathrm{O}$ cateter de silicone apresenta baixa resistência e pode ser facilmente rompido, caso não seja manipulado com delicadeza (Silva e Nogueira, 2004).

Dentre outras desvantagens, tem-se a restrição dos movimentos, quando o cateter é inserido na fossa antecubital; a fixação inadequada e a necessidade de cuidados diários semanais são as mais evidentes na manutenção diária (SOBETI, 2004).

Pezzi (2004) salienta que a principal desvantagem do cateter PICC é requerer treinamento especial para qualificação do profissional para realização do procedimento de inserção, pois consome de 45 a 60 minutos de duração e necessita de protocolos de manutenção rigorosos para prevenção de complicações.

\subsubsection{Principais indicações e contra-indicações na inserção do cateter PICC em recém-nascidos}

O cateter PICC é indicado para recém-nascidos prematuros extremos; recém-nascidos com indicação de nutrição parenteral por tempo prolongado; recém-nascidos submetidos a cirurgias e recém-nascidos com síndromes e malformações (Silva e Nogueira, 2004; Pezzi, 2004); sendo também indicado para terapias hiperosmolares e soluções com um pH não fisiológico (SOBETI, 2004). 
Para Pezzi (2004), a osmolaridade refere-se à concentração de soluto por litro de fluido e é expressa em mOsm/l. A osmolaridade sérica normal é igual a 280-295 mOsm/l. As soluções hiperosmolares apresentam osmolaridade igual ou maior a $500 \mathrm{mOsm} / \mathrm{l}$. É importante considerar que a osmolaridade da solução pode ser modificada, conforme o uso do diluente e da quantidade empregada.

$\mathrm{O} \mathrm{pH}$ refere-se à acidez ou alcalinidade das drogas e soluções. $\mathrm{O} \mathrm{pH}$ sérico é de 7,35 a 7,45; considera-se ácido ou irritante $\mathrm{pH}$ inferior a 6,0 e alcalino ou vesicante $\mathrm{pH}$ acima de 8,0. É importante salientar que o $\mathrm{pH}$ das drogas não se modifica em relação ao diluente (Pezzi, 2004).

O PICC é contra-indicado em neonatos com infecção de pele ou de tecido subcutâneo em área próxima do local a ser utilizado para punção; presença de lesões dérmicas que possam sugerir um comprometimento da integridade do cateter; alterações anatômicas e estruturais que interfiram na progressão do cateter; policitemia, pois a experiência prática evidencia que a implantação do PICC deve ser evitada em bebês com hematócrito elevado, pelo risco de obstrução do cateter em função do aumento da viscosidade sangüínea.

Outras contra-indicações encontradas, segundo a SOBETI (2004), são: edema localizado; problemas ortopédicos; dissecção venosa prévia e recusa dos pais.

Pezzi (2004) acrescenta que a plaquetopenia; coagulopatias; hematomas em recém-nascidos em ventilação mecânica de alta freqüência e situações de emergência/urgência são razões para se contra-indicar o cateter PICC.

\subsubsection{Orientações aos pais sobre o cateter PICC}

Conforme orienta a SOBETI (2004), antes de instalar o cateter PICC é preciso orientar o paciente ou responsável sobre o procedimento de inserção do cateter, sua indicação, riscos e benefícios. Após toda a orientação, é aconselhável que o paciente ou responsável assine um Consentimento PósEsclarecido, antes do procedimento de inserção. 
Para o enfermeiro que será responsável pelo procedimento de inserção do PICC, o aspecto cognitivo da família é muito importante, pois esta conduta contribui para reduzir a ansiedade da família e facilita sua adesão (Oakley, Wright, Ream, 2000).

\subsubsection{Capacitação técnica do enfermeiro para a inserção do cateter PICC}

A inserção do cateter PICC é um procedimento de alta complexidade, por isso o enfermeiro deve receber a qualificação e/ou capacitação por órgãos competentes.

A Resolução RDC nํ. 45 da Agência Nacional de Vigilância Sanitária (ANVISA) determina que cabe ao enfermeiro manter o acesso venoso periférico, incluindo a instalação do cateter PICC. Dispõe ainda que o profissional deve participar da escolha do tipo de acesso venoso central, em consonância com o médico responsável pelo atendimento do paciente (Brasil, 2003).

O Conselho Regional de Enfermagem de São Paulo lançou um parecer em 15 de março de 1999, que foi amparado pela Câmara Técnica Assistencial, no qual favoreceu e autorizou o enfermeiro a realizar o procedimento de inserção do PICC, desde que seja devidamente treinado e especializado a executar a passagem do cateter periférico, mas, para isso é preciso que exista um protocolo hospitalar (COREN, 1999).

A Sociedade Brasileira de Enfermeiros em Terapia Intensiva (SOBETI), instituída em 1996, foi a primeira a certificar e qualificar os enfermeiros brasileiros para passagem do PICC. A referida sociedade tem parceria com a ABESE (Academia Brasileira de Especialistas em Enfermagem) e juntas reforçam a atenção dos enfermeiros na importância da assistência de enfermagem em unidades de terapia intensiva, em situações de passagem e retirada do PICC (Toma, 2004). 


\subsubsection{Técnica de inserção do cateter PICC}

A inserção do cateter PICC deve contar com a técnica de barreira máxima, ou seja, uso de gorro, máscara, capote estéril, campos estéreis (Gomella, 2006).

A SOBETI (2004) e Gomella (2006) recomendam, como medidas prévias para inserção do cateter PICC: solicitar ao serviço de radiologia a presença de um técnico para realizar radiografia de tórax ao inserir o cateter; proceder à assepsia das mãos; avaliar as condições do recém-nascido; providenciar e checar o material necessário para execução do procedimento; posicionar o paciente em decúbito dorsal, mantendo o membro, preferencialmente o superior direito, em ângulo de $90^{\circ}$ em relação ao tórax; mensurar com fita métrica o perímetro braquial e a distância entre o ponto de punção e a articulação escapuloumeral, deste ponto até a fúrcula esternal e, em seguida, até o terceiro espaço intercostal.

A SOBETI (2004) orienta que a inserção do PICC siga a seguinte ordem:

Identificação da veia apropriada; posicionamento do paciente; verificação da medida do comprimento do cateter; paramentação; abertura completa do material e colocação de um campo estéril sob o local de punção escolhido; anti-sepsia; lubrificação do cateter com solução salina; preparação do comprimento do cateter; aplicação de torniquete e preparo do conjunto introdutor; execução de venopunção; retirada da agulha da bainha introdutora; inserção do cateter periférico; remoção da bainha protetora; introdução completa do cateter periférico; teste de permeabilidade do cateter; retirada do campo fenestrado; limpeza do local de inserção; fixação do disco oval; fixação do cateter; fechamento do sistema; confirmação radiológica da posição da ponta do cateter.

O cateter PICC tem vários calibres que comportam o volume a ser infundido, o mais usado em recém-nascidos é o 1,9 French de uma via (Becton Dickinson, 2000). 
Pezzi (2004) e Becton Dickinson (2000), recomendam que, para se obter sucesso na inserção do cateter PICC, é necessário: utilizar pinças esterilizadas para manipular o cateter; não forçar sua passagem ao encontrar alguma resistência; ao inserir o cateter e encontrar alguma resistência na progressão, injetar simultaneamente solução fisiológica a 0,9\% para promover a abertura das válvulas venosas e facilitar a progressão; monitorar a saturação de oxigênio e a freqüência cardíaca do recém-nascido antes e depois da inserção do cateter, observando presença de arritmias; limitar o número de punções até três vezes para evitar infecções; não usar seringas, cuja capacidade seja inferior a $5 \mathrm{ml}$, para evitar o rompimento do cateter.

Fricke, Racadio, Duckworth, Donnelly, Tamer, Johnson (2005); Gamulka, Mendoza, Connolly (2005) por meio de um estudo realizado pelo Departamento de Radiologia e de Pediatria do Hospital Cincinnati Children's, Ohio, EUA, estudaram 843 procedimentos de inserção do cateter PICC em 698 crianças que tinham média da idade 6,9 anos, durante 14 meses. $O$ objetivo do trabalho foi verificar a localização da ponta do cateter, após a sua inserção utilizando a técnica da fluoroscopia. As crianças foram divididas em dois grupos, assemelhando-se apenas a idade e a veia de escolha.

No primeiro grupo, o cateter foi inserido por enfermeiros qualificados; no segundo grupo, o cateter foi inserido por enfermeiros qualificados e com o auxílio de um técnico em radiologia e um pediatra, ambos utilizando a fluoroscopia. $\mathrm{Na}$ análise dos dados, verificou-se que $85,8 \%$ dos cateteres inseridos por enfermeiros qualificados tiveram de ser tracionados, após a radiografia de tórax porque não se encontravam em posição central e 90,2\% com a fluoroscopia estavam em posição central após a realização do exame de radiografia de tórax. A conclusão foi que a técnica de fluoroscopia diminui a manipulação do cateter depois de sua inserção. 


\subsubsection{Alívio da dor na inserção do PICC}

Como qualquer punção venosa, a inserção do PICC é um procedimento doloroso ao recém-nascido.

Segundo Silva e Nogueira (2004), antes da inserção do cateter PICC é preciso solicitar à equipe médica a analgesia ou sedação ao recémnascido.

Ballantyne, McNair, Ung, Gibbins, Stevens (2003) realizaram um estudo controlado, randomizado, duplo cego, com 49 recém-nascidos, com idade gestacional entre 27 e 41 semanas, que receberam 1,0g de tetracaína gel aplicado sobre a pele do recém-nascido. A tetracaína é um anestésico efetivo na redução da dor no procedimento de venopunção em neonatos. $O$ anestésico foi aplicado 30 minutos, antes da inserção do cateter PICC (grupo experimental). No grupo controle, creme de euricin (placebo) foi utilizado. A escala Premature Infant Pain Profile (PIPP) foi empregada para avaliar a dor no grupo controle (26 recém-nascidos) e no grupo experimental (23 recém-nascidos). O resultado mostrou que a tetracaína gel a $4 \%$ não teve efeito analgésico na inserção do cateter PICC.

Lemyre, Sherlock, Hogan, Gaboury, Moher, Blanchard (2006) realizaram estudo randomizado, duplo cego para avaliar o efeito analgésico da tetracaína gel 4\% em 54 recém-nascidos prematuros, com idade gestacional média de 27 semanas e com peso médio de 916 gramas, antes da inserção do cateter PICC. Utilizaram a PIPP para avaliar a dor em ambos os grupos, experimental e controle. $O$ anestésico foi empregado 30 minutos antes da inserção. O resultado mostrou que a tetracaína gel a $4 \%$ aplicada 30 minutos antes não apresentou redução da dor e verificou-se eritema local em três crianças.

Fry e Aholt (2001) realizaram estudo randomizado, controlado no qual avaliaram o efeito de dois anestésicos locais para alívio da dor, antes da inserção do cateter PICC. Participaram 42 pacientes de ambos os sexos e 
aplicou-se o questionário de McGill de dor para medir sua qualidade e intensidade. Assim, os 42 pacientes foram divididos em três grupos: no grupo um, utilizaram EMLA tópico; no grupo dois, lidocaína buferina e no grupo três, placebo. $O$ resultado mostrou efeito analgésico superior para lidocaína buferina do que para EMLA e placebo.

\subsubsection{Manutenção diária dos cuidados com o cateter PICC}

A manutenção diária do cateter PICC deve ser realizada por pessoal treinado e capacitado e os curativos feitos apenas pelo enfermeiro que recebeu qualificação e/ou capacitação para a inserção, manutenção e remoção do cateter.

Segundo a SOBETI (2004), o curativo realizado no PICC cumpre duas funções: cria um ambiente que protege a área onde está inserido o cateter $\mathrm{e}$ evita que haja seu deslocamento.

A troca do curativo deve ser realizada de acordo com o protocolo de cada instituição ou quando a integridade do curativo estiver prejudicada (SOBETI, 2004).

Pezzi (2004), recomenda trocar o curativo após 24 horas de inserção do cateter e depois a cada sete dias, substituindo os intermediários (conexão de dupla via, torneirinha, equipo) a cada 72 horas. Exceto quando se infunde nutrição parenteral que a recomendação é a cada 24 horas com desinfecção prévia da extensão do cateter com álcool a $70 \%$. Os autores propõem ainda que se registre data e hora do curativo e evolução de suas condições no prontuário do paciente.

A aferição da circunferência dos membros puncionados é uma medida que auxilia avaliar as condições de permeabilidade do cateter; o aumento do valor leva a suspeitar da formação de trombose ou extravasamento (Gomella, 2006).

A aferição da circunferência dos membros considera a medida da distância entre o cotovelo e o ombro, com o braço mantido em ângulo de $90^{\circ}$. Aumento superior a $2 \mathrm{~cm}$ é um sinal precoce de trombose (Becton Dickinson, 2000). 
A troca do curativo envolve a retirada manual do filme transparente, com uso de luvas esterilizadas, para retirar a fita adesiva, verificar a posição do cateter para certificar-se de que não houve deslocamento; limpar o local com gaze esterilizada embebida em solução de clorexedina a $0,5 \%$, posicionar o cateter e passar uma fita adesiva sobre o disco oval para mantê-lo no lugar; colocar novamente fitas adesivas e o filme transparente sobre o local de inserção (Becton Dickinson, 2000).

$\mathrm{Na}$ ocorrência de deslocamento e tração do cateter, nunca o inserir; evitar dobrá-lo no local da inserção, impedindo o fluxo de soluções infundidas e, conseqüentemente, complicações, como: obstrução e rompimento do cateter (Bencton Dickinson, 2000).

Pettit (2002) salienta que, para manter a permeabilidade do cateter, é necessário infundir 0,5 a $1,0 \mathrm{ml}$ de solução salina a $0,9 \%$ sob pressão positiva.

É recomendado evitar verificar a pressão arterial em extremidades onde está inserido o cateter PICC, a fim de evitar oclusões ou danificações do cateter (Gomella, 2006).

Os registros referentes à passagem do cateter e manutenção devem conter: o material escolhido; sítio de inserção; número de tentativas; intercorrências durante o procedimento; laudo da radiografia de controle pósinserção; curativos realizados; medicamentos infundidos; permeabilidade do cateter. Caso haja sinais de foco infeccioso, notificar a Comissão Central de Infecção Hospitalar (CCIH) (Barber, Booth, King, Chakreverty, 2002; Pezzi, 2004).

Segundo Silva e Nogueira (2004), para cateteres que recebem infusões contínuas, deve-se lavar o cateter a cada 6 ou 8 horas com solução salina a $0,9 \%$, para evitar a formação de trombos e sua obstrução.

Os mesmos autores citam que medicações incompatíveis pelo cateter PICC não devem ser infundidas, pois podem provocar êmbolos e obstruí-lo. 
A equipe de enfermagem deve ser orientada a fazer assepsia das conexões todas vezes que o sistema for manipulado (Unamuno, Carneiro, Chueire, Marchini, Suen, 2005).

\subsubsection{Remoção do cateter PICC nos recém-nascidos}

Segundo a SOBETI (2004), as principais causas de remoção do cateter são: término da terapia proposta; ruptura ou quebra do cateter; posicionamento inadequado do cateter; extravasamento de líquidos; presença de processo infeccioso ou inflamatório. Assim, cabe ao enfermeiro identificar qual é o motivo de remoção e descontinuar a terapia.

A remoção do cateter deve ser feita de forma asséptica e delicadamente a cada centímetro. Em caso de resistência, aplicar uma compressa úmida e morna na área acima do trajeto do cateter por 20 a 30 minutos para favorecer a vasodilatação e tentar a remoção novamente. $\mathrm{Na}$ segunda tentativa, se for mantida resistência, refazer o curativo e tentar tirálo após 12 a 24 horas (Becton Dickinson, 2000).

Silva e Nogueira (2004) citam que as principais causas da dificuldade de remoção do cateter PICC são: seu uso prolongado e sua aderência à parede vascular; ocorrência de flebite; irritação química ou mecânica dos vasos; presença de infecção; infusão de soluções em baixa temperatura, causando vasoconstrição local; espasmo venoso; movimentos do cateter contra a parede vascular.

Pezzi (2004) recomenda que, em caso de resistência, se deve radiografar a região, para eliminar a presença de nós e dobras na parte interna do cateter.

Segundo Silva e Nogueira (2004), é recomendado que a ponta do cateter seja mandada para cultura quando houver suspeita de septicemia. 


\subsubsection{Principais complicações do cateter PICC nos recém-nascidos}

Segundo Pezzi (2004), o cateter PICC comparado a outros cateteres centrais representa uma alternativa de melhor terapêutica e menor incidência de complicações.

\subsubsection{A - Complicações relacionadas à inserção do cateter}

As principais complicações que podem ocorrer são: dificuldade de progressão do cateter, mau posicionamento do cateter; sangramento, hematoma, arritmia cardíaca, punção arterial, dano e estimulação nervosa, embolia (SOBETI, 2004).

A dificuldade de progressão pode ocorrer por vários motivos, incluindo o posicionamento inadequado do paciente, venoespasmo, calibre inadequado do cateter, dissecção venosa prévia, esclerose, fechamento das válvulas, bifurcação venosa e angulação venosa acentuada (SOBETI, 2004).

O mau posicionamento pode ocorrer em razão da própria anatomia venosa do recém-nascido e por mensuração incorreta do comprimento do cateter (SOBETI, 2004).

A arritmia cardíaca é uma complicação relacionada à excitabilidade da parede miocárdica, em razão de maior progressão do cateter na direção do átrio ou ventrículo direito. Quando isso ocorrer, recomenda-se tracionar o cateter e realizar uma nova radiografia de tórax. A ponta do cateter no coração pode causar erosão, perfuração, tamponamento e abscesso cardíaco (SOBETI, 2004; Pezzi, 2004).

A punção arterial ocorre em decorrência de erro na identificação do vaso a ser puncionado. É possível identificar que houve punção arterial pela cor do sangue em razão da pulsação da artéria; ocorrência de expulsão do cateter (Pezzi, 2004).

Segundo Phillips (2001), a embolia pelo cateter pode ocorrer pela quebra externa do cateter durante sua inserção. $O$ autor recomenda radiografia para visualizar o êmbolo. 


\subsubsection{B - Complicações relacionadas à pós-inserção do cateter}

As principais complicações relacionadas à pós-inserção do cateter são: flebite; celulite; infecção sistêmica; fratura do cateter com potencial embolia; oclusão do cateter; trombose; migração do cateter (SOBETI, 2004; Ogilvie e Merlin, 2006).

A flebite é a complicação mais freqüente em recém-nascidos. Segundo Silva e Nogueira (2004), ocorre pelo mau posicionamento do cateter associado à infusão de soluções hiperosmolares e/ou vesicantes.

De acordo com os fatores causais, a flebite é classificada em mecânica, química e bacteriana. A mecânica é causada pela adoção de técnica inadequada de inserção, pelas características próprias das veias e por fatores inerentes ao paciente. Sua prevalência é maior em veia cefálica. A química é ocasionada por medicações irritantes, inadequada diluição da medicação, alta osmolaridade da solução infundida e rapidez na infusão da solução e a bacteriana tem como causa a lavagem de mãos inapropriada, preparo inadequado da pele e contaminação do cateter durante a inserção (Phillips, 2001; SOBETI, 2004).

Para Phillips (2001); Pezzi (2004), a flebite bacteriana ocorre, geralmente, após as primeiras 48 a 72 horas, depois da inserção, sendo necessário drenar a secreção purulenta do local para não acarretar septicemia e endocardite bacteriana aguda.

Segundo Pettit (2002), os principais sinais e sintomas da flebite química, são a formação de edema local, com palpação de um cordão fibroso, hiperemia e dor local.

No geral, a celulite é causada pelo Staphlococcus epidermidis ou Staphylococcus aureaus. A dor e a hiperemia no local de inserção são os sinais e sintomas mais verificados (Phillips, 2001; Pezzi, 2004).

A infecção sistêmica relacionada ao cateter ocorre em razão de sua própria colonização. Geralmente, verifica-se pelas condições do paciente (sistema imunológico imaturo); infecções prévias; múltiplos procedimentos 
invasivos que rompem a integridade da pele e técnica inadequada de manutenção (SOBETI, 2004; Gomella, 2006).

Instabilidade térmica, aumento de episódios de apnéia, intolerância alimentar, letargia e oscilação da glicemia são sinais indicativos de infecção sistêmica. Os agentes infecciosos mais freqüentes nas infecções relacionadas com os cateteres PICC são Estafilococos coagulase negativa, Estafilococos aureus e a Candida sp (Pettit, 2002; Singhal, Mishra, Bhatnagar, 2005).

Garland, Alex, Henrickson, McAuliffe, Maki (2005) realizaram estudo prospectivo randomizado, duplo cego com recém-nascidos, submetidos à inserção do cateter PICC internados na Unidade de Terapia Intensiva Neonatal. Seu objetivo foi verificar a eficácia da vancomicina-heparina administrada in bolus pelo cateter para prevenção da infecção por Staphylococcus coagulase negativa. O grupo experimental foi composto de 42 recém-nascidos (grupo vancomicina-heparina) e o grupo controle de 43 recém-nascidos, cujo resultado foi $5 \%$ do grupo experimental e $30 \%$ do grupo controle apresentaram Staphylococcus coagulase negativa. A pesquisa revelou que a solução (vancomicina-heparina) reduziu a taxa de infecção.

Ainsworth, Furness, Fenton (2001); Griffiths e Philpot (2002); realizaram estudos comparativos entre cateter PICC e cateter venoso central (CVC) com objetivo de identificar o melhor cateter para a infusão da nutrição parenteral.

Desse modo, apoiados na revisão da literatura, os autores citados acima puderam estabelecer algumas hipóteses, o cateter PICC reduz 0 número de infecções e flebites em comparação com o CVC; o custobenefício do cateter PICC é maior que o CVC, sobretudo porque a inserção do cateter PICC é realizada por enfermeiros qualificados, com uma única punção venosa. A sepse relacionada ao cateter e sua remoção e a trombose de veia cava são maiores no grupo submetido à CVC. A oclusão do cateter é 
igual aos grupos submetidos à CVC e ao PICC. Os autores concluíram que o cateter PICC é a melhor opção para pacientes gravemente doentes, mas é

necessária uma manutenção diária para evitar a remoção prematura do dispositivo por complicações.

Segundo Mahieu, De Muynck, leven, De Dooy, Goossens, Reempts (2001); Klein, Rood, Graham (2003), o cateter venoso central (CVC) é associado a muitas complicações. Há estudos que incluem grupos variados de pacientes, que recebiam várias terapias endovenosas e com sepse relacionada ao cateter. Em recém-nascidos, os trabalhos mostram uma incidência maior em comparação com o cateter PICC. O prematuro é o mais susceptível em se tratando de sepse pelo uso do CVC.

Chaitowitz, Heng, Bell (2006); Turcotte, Dube, Beauchamp (2006) descrevem algumas complicações que podem ocorrer, tanto no PICC como no cateter venoso central (CVC). A primeira complicação mais observada, foi a infecção sistêmica, causada por Estafilococos aureus e Estafilococos coagulase negativa. A segunda, é a formação de fibrina na luz do cateter por falta de manutenção que oclui o cateter; a terceira e mais séria complicação, é a trombose que ocorre sobretudo dependendo da localização do cateter. CVC inserido em veia subclávia e ponta do cateter PICC posicionada em veia subclávia são fatores de risco para aparecimento de trombose.

A fratura do cateter pode levar a embolia que é verificada pela quebra do cateter, decorrente de excessiva pressão exercida do êmbolo da seringa ao lavar o cateter com solução fisiológica a 0,9\%, por fixação inadequada do cateter e por dano ao corpo do cateter (SOBETI, 2004).

Chow, Friedman, Macarthur, Restrepo, Temple, Chait, et al. (2003) realizaram um estudo retrospectivo, analisando 1.650 PICCs introduzidos em crianças. Encontraram $11(0,6 \%)$ fraturas de cateter com embolia em artéria pulmonar direita e esquerda, veia cava superior e átrio direito.

Para Macklin (2000); Pigna, Bachiocco, Fae, Cuppini (2004), o uso do cateter PICC é uma prática comum nas Unidades de Terapia Intensiva Neonatal para administração de nutrição parenteral e certas drogas. 
Comparado com outros cateteres, o PICC é que apresenta menos complicações, porém sua manutenção deve ser diária.

Os referidos autores descrevem dois casos de fraturas no cateter PICC, sendo o primeiro em um neonato do sexo masculino, com 36 semanas de idade gestacional, com diagnóstico de gastrosquise. Poucas horas após seu nascimento, fez cirurgia de correção e necessitou de um cateter PICC que foi inserido na veia basílica, cujo exame radiológico mostrou que a ponta estava posicionada em veia cava superior. O neonato recebeu nutrição parenteral e dopamina com analgésicos em dupla via com a velocidade de infusão de $9,5 \mathrm{ml} / \mathrm{h}$ pelo cateter PICC. Nos dias subseqüentes, houve piora do padrão respiratório e foi solicitada radiografia de tórax que constatou fratura do cateter PICC e fragmentos em artéria pulmonar esquerda.

O cateter foi retirado e o recém-nascido não mostrou nenhuma seqüela. O segundo caso, é de um recém-nascido de 34 semanas, sexo masculino, com suspeita de atresia esofagiana, foi inserido um cateter PICC em veia basílica de membro superior direito. $O$ neonato recebeu nutrição parenteral e dopamina, com velocidade máxima de $6 \mathrm{ml} / \mathrm{h}$. Após dez dias, o recém-nascido apresentou apnéia aguda, seguida de bradicardia e cianose. A radiografia mostrou alteração na área pulmonar e a ponta do PICC havia migrado à artéria pulmonar esquerda, com presença de fluido na cavidade pleural. O neonato recebia, há dois dias, ventilação de alta freqüência. Após a remoção do cateter PICC, houve melhora de suas condições.

Chen, Liang, Huang, Chung (2006) relatam o caso de um recémnascido de 27 semanas, pesando 740 gramas, sexo feminino; um cateter PICC de silicone foi inserido na veia femural para administração da nutrição parenteral no terceiro dia de vida. O exame de radiografia de tórax mostrou que a ponta do cateter PICC posicionava-se em veia cava inferior, em relação a nona vértebra torácica, sendo liberado para uso. $O$ cateter foi mantido por 53 dias e ao ser removido, apenas $5 \mathrm{~cm}$ dele foram sacados. A radiografia do tórax mostrou que o cateter estava em área cardíaca. Com auxílio do ecocardiograma, localizaram sua porção remanescente. O 
fragmento foi retirado através do cateterismo. Os autores alertam para as prováveis causas de ruptura do cateter, como a prática do "flushing", utilizando seringas com volumes inferiores a $10 \mathrm{ml}$, tentativas repetidas de desobstrução do cateter, quebra no sítio de inserção e remoção descuidada que favorecem a fratura do cateter e levam a migração de segmento, com complicações graves ao paciente.

A oclusão do cateter é em razão de "flush" inadequado; refluxo sangüíneo excessivo; medicações incompatíveis (formação de cristais); baixa solubilidade (SOBETI, 2004; Hadaway, 2006).

Segundo Fetzer e Manning (2004), o cateter PICC é uma excelente alternativa para terapias de longa permanência, mas em razão de má manutenção do cateter pode ocorrer a oclusão do lúmen e ocasionar sua remoção. Muitos cateteres rompem-se na tentativa de desobstruí-lo. Os autores relatam um estudo utilizando seringas de cinco e dez $\mathrm{ml}$ com $1 \mathrm{ml}$ de solução salina em cada uma, sendo conectada uma torneira de duas vias no cateter obstruído, onde se colocam as seringas de cinco e dez $\mathrm{ml}$ em cada lado. A técnica é injetar com a seringa de dez $\mathrm{ml}$ e aspirar com a de cinco $\mathrm{ml}$, sucessivamente. Os autores ressaltam não utilizar seringas menores que cinco $\mathrm{ml}$ para esta técnica.

Hoffer, Bloch, Borsa, Santulli, Fontaine, Francoeur (2001) salientam que, em razão da preocupação de muitos fabricantes com relação a altas porcentagens de oclusão e infecção pelo cateter PICC, desenvolveram o cateter PICC valvulado, que mostrou ser superior ao não valvulado.

Assim, o cateter valvulado evita que haja formação de coágulos no lúmen do cateter pela interrupção do fluxo sangüíneo. Por meio de um estudo prospectivo e randomizado, os autores citados compararam os dois tipos de PICCs, com o objetivo de verificar se os cateteres valvulados são mais benéficos. Durante cinco meses, foram estudados 285 PICCs em 211 pacientes, com idade média de 46 anos. Todos os cateteres foram inseridos através da fluoroscopia ou do ultra-som e a maioria era para infusão de antibióticos (91\%) por mais de sete dias. Os cateteres valvulados $(n=52)$ e os não valvulados $(n=48)$ foram posicionados em veia cava. 
Assim, os resultados mostraram que 12 pacientes (25\%) com cateter não valvulado e seis (11,5\%) pacientes com cateteres valvulados apresentaram oclusão ou infecção. A conclusão dos autores foi que existe diferença na durabilidade entre os cateteres valvulados, com menores taxas de oclusão e/ou infecção.

A colocação do cateter na posição midclavicular pode aumentar o risco de trombose por causa da curvatura do vaso, permitindo maior contato entre o revestimento endotelial (Becton Dickinson, 2000).

Janes, Kalyn , Pinelli, Paes (2000); Chemaly, de Parres, Rehm, Adal, Lisgaris, Katz-Scott, et al. (2002), referem que o cateter PICC tem sido muito utilizado para administração de nutrição parenteral e antibiótico, mas, quando sua ponta não está central, podem ocorrer várias complicações como: tromboflebite, flebites e oclusões. A infusão de soluções hiperosmolares e drogas incompatíveis também favorece a ocorrência dessas complicações. A incidência de trombose em cateteres PICC varia de 0,3 a 56 .

A trombose é causada por oclusão do cateter, lesão da parede vascular; fluxo insuficiente ou tamanho inapropriado do cateter em relação ao vaso; estase venosa; soluções hipertônicas e mau posicionamento do cateter. Os principais sintomas são: edema; impossibilidade de aspiração; infusão lenta; desconforto no ombro e pescoço; taquicardia e dispnéia (Silva e Nogueira, 2004; SOBETI, 2004).

Abdullah, Mohammad, Sangkar, Abd Aziz, Gan, Goh, et al. (2005) estudaram 26 pacientes prospectivamente, objetivando verificar a incidência de trombose em pacientes com cateteres PICCs, cujas pontas estavam em região não central. A idade dos pacientes variou de 15 a 70 anos e a maioria era chinês, $46 \%$. A maioria dos PICCs foi inserida em razão de uma longa terapia antimicrobiana (65\%), utilizou-se um venograma para monitorar a formação de trombo. Nenhum desses pacientes fazia uso de anticoagulantes ou doses baixas de heparina. O resultado foi que $60 \%$ apresentaram trombose e a ponta do cateter estava em posição midclavicular. 
Smith, Friedell, Cheatham, Martin, Cohen, Horowitz (1998) referem que por meio de um estudo retrospectivo com 555 PICCs, a porcentagem da população, a que é indicado o cateter PICC, é a que necessita da infusão da nutrição parenteral por longo tempo. Os autores salientam que as complicações mais comuns que ocorrem são: flebite, trombose, oclusão, migração e infecção.

Hyman e Cardenas (2002) relatam dois casos de trombose verificados, após uma venografia contrastada. O primeiro, é de um homem de 40 anos, que estava com um PICC no membro superior esquerdo, inserido na veia cefálica, cuja ponta do cateter estava localizada na veia subclávia. Após uma piora clínica, com hipertermia $\left(39^{\circ} \mathrm{C}\right)$, edema cervical e dor local foi realizado um ultra-som que mostrou um trombo no local da ponta do PICC. A conduta foi retirar o cateter e mandar sua ponta para cultura. A cultura da ponta foi positiva para a bactéria Staphyloccus coagulase negativa. $O$ segundo caso, foi de um homem de 50 anos, em que foi inserido um cateter PICC de poliuretano na veia basílica do membro superior direito. A ponta do cateter ficou localizada na veia braquial e, após alguns dias, verificou-se a formação de um trombo. As condições clínicas do paciente foram piorando, e o membro superior direito e a região cervical ficaram edemaciados.

Allen, Megargell, Brown, Lynch, Singh, Singh, et al. (2000) referem que a inserção do cateter PICC pode trazer sérias conseqüências se não for realizada uma manutenção diária, sobretudo se o cateter estiver com sua ponta localizada fora da veia cava superior. Os autores realizaram um estudo retrospectivo, de 1992 a 1998, constataram que a realização da fluoroscopia auxiliava na inserção do cateter PICC e a venografia, na definição do diagnóstico de trombose venosa. Nos seis anos, identificaram 3.054 PICCs. A idade dos pacientes variou de seis meses a 83 anos, com média de idade de 35,2 anos. Identificaram 144 PICC periféricos, dos quais 76 instalados em membro superior direito e 68 em membro superior esquerdo. Dentre os 144 PICCs periféricos, 137 fizeram venografia. As veias puncionadas foram: basílica, $85 \%$; braquial, 6,2\%; cefálica, $6,5 \%$ e outras. A 
comparação era feita com venogramas realizados no início do uso do cateter PICC e quando ocorria a suspeita de trombo. Dos 137 cateteres estudados, $48,4 \%$ apresentaram trombose em veia subclávia, onde estava localizada a ponta do cateter, sendo $57 \%$ inseridos pela veia basílica.

A migração do cateter ocorre por movimentação vigorosa da extremidade onde se inseriu o cateter PICC; fixação inadequada do cateter; alterações da pressão intratorácica (SOBETI, 2004).

Nowlen, Rosenthal, Johnson, Tom, Vargo (2002) desenvolveram um estudo retrospectivo em seis instituições, entre 1995 e 1998, com o objetivo de descrever casos de tamponamento cardíaco por infusão de nutrição parenteral em crianças, com idade gestacional média de 30 semanas. Dentre essas seis instituições, encontraram 14 casos referidos como tamponamento cardíaco. As características relatadas pelos neonatologistas nos prontuários foram: bradicardia, hipotensão, alteração do padrão respiratório, instabilidade hemodinâmica. Em seis casos, com o auxílio do ecocardiograma conseguiram realizar pericardiocêntese e apenas em dois casos obtiveram êxito. Nos pacientes que faleceram, constatou-se na autópsia, resíduos de nutrição parenteral no pericárdio.

Pezzati, Filippi, Chiti, Dani, Rossi, Bertini, et al. (2004) conduziram um estudo retrospectivo por oito anos, com um total de 258 PICCs, inseridos em recém-nascidos com peso menor de 1.500 gramas, para determinar a incidência de tamponamento cardíaco. $O$ resultado encontrado foi que dos 258 PICCs inseridos, cinco recém-nascidos apresentaram tamponamento cardíaco entre o $1^{\circ}$ ao $13^{\circ}$ dias pós-inserção do PICC. Dois recém-nascidos desenvolveram rápida assistolia, sem sucesso na reanimação. A autópsia mostrou acúmulo de $9 \mathrm{ml}$ de fluido similar à nutrição parenteral na cavidade pericárdica. Três pacientes responderam após uma pericardiocêntese. Utilizaram o ecocardiograma e o exame de radiografia de tórax, com os quais constataram a migração do cateter.

Nadroo, Magid, Lin, Green, Holzman (2001); Bagtharia, Kempley, Hla (2001), relatam dois casos de tamponamento cardíaco causados pelo cateter 
PICC em recém-nascidos. O primeiro paciente era um pré-termo de 34 semanas de gestação que, após quatro dias da inserção do cateter PICC, desenvolveu bradicardia e hipotensão, não respondendo às manobras de reanimação. A autópsia revelou $33 \mathrm{ml}$ de nutrição parenteral no pericárdio e que a ponta do cateter havia migrado ao átrio direito. O segundo paciente tinha 26 semanas, com peso aproximado de 610 gramas. O recém-nascido estava com parâmetros mínimos na ventilação mecânica. Após cinco dias, foi inserido o cateter PICC no membro superior direito, em veia cubital para infusão de nutrição parenteral. A ponta do cateter posicionou-se em veia cava superior. Após seis dias, apresentou bradicardia severa e hipotensão. Manobras de ressuscitação e administração de adrenalina foram realizadas sem sucesso. A autópsia revelou $9,5 \mathrm{ml}$ de nutrição parenteral no pericárdio. A causa da morte foi determinada, como tamponamento cardíaco ocasionado por migração do cateter.

Poucos pacientes são ressuscitados com sucesso, quando ocorre o tamponamento cardíaco. Quando se verificam os sinais e sintomas a tempo, consegue-se pela pericardiocêntese reverter o quadro, mas a morte súbita pode ocorrer na ausência de qualquer sinal (Nadroo, Magid, Lin, Green, Holzman, 2001). Recomenda-se atenção redobrada para evitar a migração do cateter, realizando esporadicamente radiografias de tórax durante a manutenção, mensurando o comprimento do cateter antes da inserção.

D'Elia, Correia, Oliveira, Barbosa (2002) relatam um caso em que ocorreu falso trajeto do cateter venoso de inserção periférica, com fístula vasculopulmonar e grave conseqüência respiratória ao recém-nascido prematuro que permaneceu na Unidade de Terapia Intensiva Neonatal para tratamento de Doença da Membrana Hialina e de infecção manifestada posteriormente. A descrição do caso foi obtida por meio de revisão do prontuário. No dia seguinte à inserção do cateter PICC, o quadro de desconforto respiratório iniciou-se e progrediu rapidamente, necessitando de ventilação mecânica para estabelecer as trocas gasosas. A verificação do trajeto do cateter pelo exame de radiografia de tórax revelou a migração 
extravascular do PICC e a presença de complicação. Esta é extremamente rara e os autores identificaram apenas um caso de fístula bronquioarterial (a partir de ramificação da artéria pulmonar), diferindo do caso estudado, que era uma fístula bronquiovenosa (a partir da veia cava superior). Os diagnósticos prováveis de pneumonia lipídica e edema pulmonar foram estabelecidos. Após a retirada do cateter, houve rápida melhora clínica e radiológica, com extubação em dois dias. Os autores salientam a importância de monitorização semanal do cateter para que na vigência de uma migração possa haver uma resolução rápida do caso.

O cateter central de inserção periférica tem sido muito utilizado nas Unidades de Terapia Intensiva Neonatal (Pignotti, Messineo, Indolfi, Donzelli, 2004). Os autores relatam um caso de um recém-nascido de 850 gramas, sexo feminino, com 30,5 semanas. Com três dias de vida, foi inserido um cateter PICC no membro superior direito para administração da nutrição parenteral. Após ser realizado o exame de radiografia de tórax e depois de dois dias de uso do cateter, o recém-nascido apresentou apnéia aguda. A radiografia foi repetida e mostrou uma massa compacta no lobo direito do pulmão. O neonato piorava a cada dia, após um novo exame de radiografia verificou-se uma massa bilateral do lobo pulmonar direito, pela migração do PICC à artéria pulmonar direita. O cateter foi tracionado e reposicionado na veia cava superior. Em poucas horas, houve uma melhora das condições clínicas do recém-nascido.

Parikh e Narayanan (2004) relataram um caso de um rapaz de 15 anos que realizou uma apendicetomia, tendo sido inserido um cateter PICC para receber antibiótico. Após duas semanas, o rapaz relatou dores fortes de cabeça, dificuldade para se vestir, alimentar-se e realizar qualquer movimento. A ressonância magnética revelou isquemia de gânglios basais, sem evidência de trombos ou outra complicação. A ultra-sonografia mostrou que a ponta do cateter havia migrado para a artéria subclávia, obstruindo a artéria carótida. O PICC foi retirado imediatamente. 
Meeks, Ciambotti, Rodgers, Gordon (2003) relatam o caso de um recém-nascido do sexo feminino com oito dias de vida, pesando 4.900 gramas e idade gestacional de 35 semanas. O cateter PICC foi instalado para infusão de NPT. No sexto dia, após inserido o PICC, o neonato passou a receber nutrição enteral e parenteral. No segundo dia, apresentou dificuldade respiratória e o exame de radiografia de abdome mostrou uma massa compacta no quadrante superior do fígado. Pela tomografia computadorizada, identificou-se coleção de fluido de nutrição parenteral intra-hepática, pela migração do cateter PICC à artéria hepática.

Segundo Mitsufuji, Matsuo, Kakita, Ikuta (2002), o mau posicionamento do cateter PICC em razão da migração do cateter é uma complicação que pode ocorrer se não for feita a devida manutenção. Os autores relatam um caso de migração em um recém-nascido de 28 semanas. No $12^{\circ}$ dia de vida do neonato um cateter PICC foi inserido na veia safena no membro inferior direito. Pelo exame de radiografia de tórax, observaram que a ponta do cateter estava posicionada na veia cava inferior. Após 14 dias com o PICC, o recém-nascido apresentou desconforto respiratório, apnéia e uma proteína $C$ reativa de $1,2 \mathrm{mg} / \mathrm{dl}$. No $17^{\circ} \mathrm{dia}$, com a piora clínica, foi colhido um líquor que revelou uma leucocitose acentuada e diagnosticou-se meningite. No $20^{\circ}$ dia, observaram a formação de um edema cervical e aumento da proteína $C$ reativa para $4,3 \mathrm{mg} / \mathrm{dl}$. Um novo exame de radiografia de tórax foi feito. Os autores constataram que a ponta do cateter PICC havia migrado à região vertebral, com vazamento da nutrição parenteral no espaço epidural, assim, o cateter PICC foi removido imediatamente.

Wu, Takeuchi, Imanaka, Higuchi, Kagisaki (2006) relatam um caso de uma criança de cinco meses, cardiopata que, após uma cirurgia cardíaca, necessitou da inserção do cateter PICC para infusão da nutrição parenteral. O cateter foi inserido na veia basílica, no membro superior direito, sua ponta ficou localizada na veia inominada, sendo o cateter retirado após duas semanas. Depois de uma piora respiratória da criança, um exame de 
radiografia de tórax foi realizado e foi observada uma mancha na parede torácica. Um ecocardiograma foi feito e revelou líquido na cavidade pleural e oclusão da veia inominada. Com uma toracocentese, diagnosticou-se um quadro de quilotórax. Os autores concluíram que foi uma complicação decorrente da má posição da ponta do cateter PICC e que cateteres posicionados fora da veia cava possuem o dobro de chance de apresentar complicação. O risco para a formação de trombo é bem maior em cateteres não centrais, bem como as alterações hemodinâmicas. $O$ uso de heparina para prevenir o tromboembolismo em crianças e neonatos ainda é muito questionável. Sabe-se que a cirurgia cardíaca pode alterar a circulação periférica, fazendo com que haja resistência do retorno venoso para as extremidades e maior probabilidade de formação de quilotórax. 


\section{OBJETIVOS}

2 OBJETIVOS

2.1 Objetivo Geral 
Descrever as práticas de inserção, manutenção e remoção do Cateter Central de Inserção Periférica (PICC) em recém-nascidos internados na Unidade de Terapia Intensiva Neonatal (UTIN).

\subsection{Objetivos Específicos}

- Caracterizar os recém-nascidos submetidos ao procedimento da inserção do cateter PICC quanto a: sexo, idade gestacional ao nascimento, idade gestacional corrigida na data da inserção do PICC, peso de nascimento, peso na data da inserção do cateter, idade cronológica na data do procedimento, diagnóstico clínico, freqüência cardíaca antes e após as punções venosas, tratamento parenteral instituído via cateter PICC;

- Verificar a freqüência de punções venosas realizadas nos recém-nascidos submetidos à inserção do cateter PICC;

- Listar os motivos de insucesso nas punções realizadas e as intercorrências observadas;

- Identificar a localização da ponta do cateter no momento da fixação;

- Caracterizar as práticas assistenciais adotadas durante a manutenção do cateter PICC;

- Verificar o tempo de permanência do cateter PICC e as indicações de sua remoção;

- Verificar o resultado obtido da cultura de ponta do cateter PICC. 


\section{MÉTODO}

\section{MÉTODO}

\subsection{Desenho do estudo}

Trata-se de um estudo observacional, com delineamento longitudinal e coleta prospectiva dos dados sobre o manejo do dispositivo PICC em recém-nascidos. 
O valor dos estudos com delineamento longitudinal é a sua capacidade para demonstrar as mudanças que se sucedem ao longo do tempo e as seqüências em que ocorrem os fenômenos e os critérios empregados para estabelecer causalidade. Convencionalmente, o termo longitudinal significa coleta de dados em diversos pontos ao longo do tempo (Polit, Beck, Hungler, 2004).

\subsection{Local do estudo}

A pesquisa foi desenvolvida na UTIN do Berçário Anexo à Maternidade do Hospital das Clínicas da Faculdade de Medicina da Universidade de São Paulo. A unidade neonatal é composta por cinco setores: baixo risco, médio risco, alto risco, isolamento e UTI, totalizando 63 leitos. A UTIN dispõe de oito leitos.

O serviço conta com um quadro de 17 enfermeiras, das quais sete possuem certificação para realização do procedimento de instalação do cateter PICC, conferida pela Sociedade Brasileira de Terapia Intensiva (SOBETI).

O procedimento de inserção do cateter PICC foi introduzido como parte dos cuidados aos recém-nascidos internados nesse serviço em 1997, e o primeiro procedimento foi realizado por uma enfermeira e um médico. Constituiu-se de um grupo composto por dois médicos e duas enfermeiras que realizavam o procedimento nos recém-nascidos com indicação para uso do dispositivo. No início foi elaborado um impresso para registro dos dados de identificação e caracterização dos recém-nascidos, além de constatar as especificações sobre o cateter PICC, intercorrências observadas na execução do procedimento, observações de controle, cuidados realizados na manutenção e remoção do cateter.

A partir de 2001, houve aumento na freqüência de indicações do uso do cateter nos recém-nascidos internados na UTI neonatal e isolamento. No mesmo período, as enfermeiras que atuavam na UTI neonatal, obtiveram certificação profissional para realização do procedimento, freqüentando os cursos ministrados pela SOBETI. Em 2002, o serviço contava com dez 
enfermeiras com certificação conferida pela SOBETI, assim o grupo assumiu o procedimento, como de sua atribuição.

Os dados obtidos do registro de gerenciamento de procedimentos da unidade mostram que, em 2004, foram realizados 44 procedimentos de implantação do PICC na UTI neonatal, sendo contabilizados apenas os cateteres em posição central, ou seja, cuja ponta posicionou-se na veia cava superior. Os cateteres Midclavicular e Midline e inserções de cateteres que resultavam em insucesso na passagem não constavam do registro a não ser nos prontuários dos próprios recém-nascidos submetidos ao procedimento.

Desse modo, a falta de dados dificultou o levantamento preciso do total de recém-nascidos, submetidos à passagem do PICC desde que o procedimento passou a ser parte dos cuidados neonatais na unidade estudada.

Vale lembrar que o procedimento de inserção do cateter PICC é realizado na UTIN com recém-nascido mantido na incubadora.

A opção por manter uma via de acesso venoso central por meio do PICC é uma decisão consensual entre a enfermeira plantonista e o médico responsável pelo paciente.

O procedimento da inserção do cateter PICC é realizado por enfermeiras qualificadas, após a estabilização clínica do recém-nascido na UTI. Nos casos em que há indicação da inserção do PICC, os acessos venosos disponíveis são analisados e priorizadas as veias de membros superiores. Nos recém-nascidos com edema de membros superiores e com instabilidade hemodinâmica, aguarda-se, no mínimo, 48 horas para realização do procedimento. Recomenda-se às equipes médica e de enfermagem que evitem puncionar o membro previamente avaliado, como local de melhor acesso para inserir o cateter PICC.

Antes da realização do procedimento, o médico de plantão e a enfermeira qualificada verificam os resultados laboratoriais do recémnascido, avaliam os riscos e os benefícios de submeter o recém-nascido ao procedimento naquele momento, sendo a decisão de inserir o cateter PICC de responsabilidade da equipe que assiste o recém-nascido. 
As etapas do procedimento de inserção, manutenção e remoção do cateter PICC seguem as recomendações adotadas pelo curso oferecido pela Sociedade Brasileira de Enfermeiros em Terapia Intensiva.

O procedimento de inserção do cateter PICC na unidade neonatal da instituição é realizado por uma enfermeira qualificada e uma enfermeira auxiliar, com certificação ou não. A responsabilidade pelo manejo do cateter PICC desde sua inserção até a remoção é da equipe de enfermeiras certificadas, como também seu manuseio para infusão de medicamentos e nutrição parenteral.

Após a introdução do cateter PICC, solicita-se um exame radiográfico do tórax para localizar a posição de sua ponta. No intervalo de período entre a inserção do cateter à obtenção do exame radiográfico, o cateter é mantido em solução de heparina $2 U$ para evitar a obstrução da luz do cateter por formação de coágulos.

O curativo do cateter, mantido ocluído, é realizado com filme transparente e fita adesiva (steri-strip ${ }^{\circledR}$ ). Preferencialmente, a troca do curativo sempre é feita pela enfermeira que inseriu o cateter no neonato.

Em caso de obstrução do cateter, as enfermeiras com certificação procedem sua desobstrução. Caso não obtenham sucesso na manobra, o cateter é removido e a ponta é encaminhada ao laboratório para verificar o crescimento de cultura, esta solicitação não é um procedimento de rotina, cuja decisão é consensual entre a enfermeira que procedeu a remoção do cateter e o médico plantonista, responsável pelo neonato.

\subsection{Casuística}

A casuística do presente estudo constituiu-se dos procedimentos de implantação do cateter PICC nos recém-nascidos internados na UTIN, realizados por enfermeiras que atuam na instituição, campo de estudo, no período entre março e setembro de 2006.

Nesse período, foram inseridos 37 cateteres PICC. Cabe ressaltar que o planejamento inicial da coleta de dados previa um período de seis meses, 
entretanto, em função de interrupção na internação por duas semanas, a coleta foi prorrogada em duas semanas.

\subsection{Critérios de inclusão}

Recém-nascidos com indicação de inserção do cateter PICC;

Recém-nascidos, cujo responsável consentisse sua participação no estudo.

\subsection{Critérios de exclusão}

Pelo fato da pesquisadora compor a equipe de enfermeiras certificadas, os procedimentos de inserção do cateter PICC realizados pela pesquisadora na instituição, campo de estudo, foram excluídos da pesquisa.

Recém-nascidos com cateter PICC transferidos para outra unidade de internação ou instituição hospitalar também foram excluídos.

\subsection{Variáveis do Estudo}

As variáveis referem-se ao perfil dos recém-nascidos que fizeram parte do estudo e as etapas de inserção, manutenção e remoção do cateter PICC, descritas, a seguir:

3.6.1 Variáveis de caracterização dos recém-nascidos submetidos ao procedimento de inserção do cateter PICC

Idade gestacional de nascimento; corresponde à idade gestacional em semanas calculada a partir da data do último período menstrual ou pela ultra-sonografia;

Idade gestacional corrigida: soma da idade gestacional ao nascimento com dias de vida na data do procedimento; 
Peso de nascimento: peso em grama, obtido na primeira hora de vida;

Peso na data do procedimento: peso em grama na data da inserção do cateter PICC;

Sexo do recém-nascido: feminino ou masculino;

Diagnóstico Clínico: diagnósticos médicos listados na data do procedimento obtido do registro de prontuário;

Terapia parenteral instituída: solução prescrita para ser infundida pelo cateter PICC.

\subsubsection{Dados relacionados à inserção, manutenção e remoção do cateter PICC}

Tipo e dose de analgésico ou sedativo administrado: princípio ativo e dose em miligramas;

Características do cateter: comprimento em centímetros, composição do material, diâmetro do calibre;

Local de inserção do cateter: segmento corporal puncionado, circunferência do membro mensurada em centímetros, identificação da veia puncionada;

Freqüência cardíaca: número de batimentos cardíacos por minuto;

Saturação de oxigênio: valor porcentual obtido por oxímetro de pulso;

Número de punções: freqüência de punções venosas realizadas nos recém-nascidos;

Resultado de punção: sucesso ou insucesso em cada punção venosa;

Motivos do insucesso: oclusão do introdutor, transfixação venosa, punção arterial, vasoespasmo, posição do recém-nascido, medida inadequada, fragilidade vascular, outros. Variáveis dicotômicas - sim ou não;

Tipos de intercorrências na inserção: bifurcação da veia, hematoma, embolia, arritmia cardíaca, ponta mal localizada, alteração da viscosidade sangüínea, outras. Variáveis dicotômicas - sim ou não.

Localização da ponta do cateter pelo exame de radiografia de tórax: posição da ponta do cateter PICC visualizada pela radiografia;

Solução parenteral infundida; 
Número e intervalo dos curativos realizados: freqüência de curativos e intervalos em dias;

Anti-séptico empregado no curativo;

Circunferência em centímetros do membro;

Medida do cateter externo: comprimento em centímetros da porção do cateter não inserida na veia;

Permeabilidade: condição em que há passagem da solução através da luz do cateter, variável dicotômica - sim ou não;

Uso de tala: uso de dispositivo no membro onde o cateter está inserido com o objetivo de proteger o local de inserção do cateter, variável dicotômica - sim ou não;

Aspecto do local de inserção do cateter: endurecimento, secreção, presença de dobras, hiperemia, hematoma, outros. Variáveis qualitativas dicotômicas - sim ou não;

Complicações: infiltração/edema, flebite/celulite, infecção/septicemia, trombose/tromboflebite, oclusão/obstrução, deslocamento do cateter, fratura do cateter, migração do cateter, embolia gasosa, tamponamento cardíaco, sangramento, outras. Variáveis qualitativas dicotômicas - sim ou não.

Motivos de remoção do cateter: término da terapia proposta, obstrução, infecção, aumento da circunferência membro, exteriorização, extravasamento, fratura, óbito, outros. Variáveis qualitativas dicotômicas sim ou não.

\subsection{Instrumento de Coleta de Dados}

As variáveis do instrumento de coleta de dados foram codificadas previamente à coleta (Anexo II), seguindo a seguinte distribuição:

* Parte I-Caracterização do recém-nascido;

* Parte II - Inserção do PICC;

* Parte III - Manutenção PICC;

* Parte IV - Remoção do PICC. 
$\mathrm{Na}$ Parte I, registraram-se dados referentes à:

Idade gestacional de nascimento;

Idade gestacional corrigida na data da inserção;

Peso de nascimento;

Peso na data da inserção;

Sexo;

Dias de vida na data da inserção do cateter;

Indicação para uso do cateter PICC;

Resultado de hemocultura antes do procedimento;

Resultado de hemocultura antes do procedimento;

Resultado do exame de Proteína C Reativa;

Resultado do hematócrito.

A Parte II do instrumento de coleta dos dados, registrou os seguintes dados:

Fármaco analgésico e/ou sedativo utilizado;

Tipo de cateter selecionado;

Freqüência de punções realizadas;

Freqüência cardíaca pré e pós-inserção;

Saturação de oxigênio pré e pós-punção;

Local de punção (membros e veias mais acessadas);

Motivos de insucesso na inserção do cateter;

Intercorrências na inserção;

Local posicionado pela ponta do cateter pelo exame de radiografia de tórax;

Tração do cateter;

Posição da ponta do cateter pós-tração;

Posição da ponta do cateter - Central, Midclavicular e Midline;

Extensão (em centímetros) do cateter introduzido;

Realização de ecocardiograma;

Posicionamento do cateter pelo ecocardiograma;

Tempo decorrido entre inserção do cateter e o exame de radiografia de tórax; 
Tempo decorrido entre a tração do cateter e segundo exame de radiografia de tórax.

$\mathrm{Na}$ Parte III do instrumento de coleta de dados foram registrados dados referentes à manutenção do cateter PICC:

Solução infundida pelo cateter;

Data do curativo;

Anti-séptico utilizado;

Alterações no sítio de inserção;

Material de oclusão;

Solução infundida;

Uso de antibióticos;

Permeabilidade do cateter;

Uso de tala;

Intercorrência pós-inserção;

Tempo de permanência do cateter.

$\mathrm{Na}$ Parte IV do instrumento de coleta dos dados, foram registrados os dados sobre a remoção do cateter:

Motivos da remoção do cateter;

Característica do cateter removido;

Comprimento total do cateter pós-remoção;

Resultado da cultura da ponta do cateter.

\subsection{Procedimentos para a coleta de dados}

Os dados referentes à Parte I do instrumento de coleta dos dados foram obtidos do prontuário médico do recém-nascido.

Os dados referentes à Parte II, com as enfermeiras que realizaram o procedimento de inserção do cateter PICC e pela observação da execução do procedimento. Esta foi realizada pela própria pesquisadora e pelas profissionais da equipe de enfermagem, previamente orientadas quanto ao preenchimento do instrumento de coleta de dados. 
Os dados referentes à Parte III foram obtidos com as enfermeiras que realizaram os curativos dos cateteres, por consulta aos prontuários dos recém-nascidos e observação dos procedimentos de curativo realizados pelas enfermeiras.

Os dados referentes à Parte IV foram obtidos com as enfermeiras que removeram o cateter, pelo registro de prontuário médico e pela observação do procedimento de remoção do cateter realizado pela pesquisadora.

\subsection{Organização, tratamento e análise de dados}

Os dados registrados nos impressos do instrumento de coleta foram transferidos para planilha eletrônica, aplicativo Microsoft Excel e transportados ao programa Epi-Info 3.3.2 para seu processamento.

Sua análise descritiva e os resultados obtidos foram realizados e apresentados sob a forma de tabelas. Estas com a freqüência absoluta $(\mathrm{N})$ e relativa (porcentuais) das classes de cada variável estudada. Médias, medianas, valores máximos e mínimos e desvio-padrão foram calculados para as variáveis quantitativas.

As freqüências absoluta $(\mathrm{N})$ e relativa (porcentuais) dos dados referentes às variáveis classificatórias foram calculadas.

\subsection{Aspectos éticos}

Em observância às determinações da Resolução 196/96, do Conselho Nacional de Saúde, que dispõe sobre as diretrizes e normas regulamentadas de pesquisa envolvendo seres humanos, este projeto foi submetido à análise pelo Comitê de Ética para Análise de Projetos de Pesquisa da Diretoria Clínica do Hospital das Clínicas da Faculdade de Medicina da Universidade de São Paulo (HCFMUSP), cadastrado na Comissão Nacional de Ética em Pesquisa (CONEP). 
Anexado ao projeto de pesquisa constavam: Termo de Consentimento Livre e Esclarecido do responsável pelo recém-nascido (Anexo III) e Termo de Consentimento Livre e Esclarecido do enfermeiro responsável pela execução da prática de inserção do cateter (Anexo IV); e emissão da Carta de Aprovação pelo Comitê de Ética em Pesquisa (Anexo V). 


\section{RESULTADOS}

\section{RESULTADOS}

4.1 Caracterização dos recém-nascidos submetidos ao procedimento de inserção do PICC

No período de março a agosto de 2006, trinta e sete recémnascidos foram submetidos ao procedimento de inserção do cateter PICC.

Os dados de caracterização dos recém-nascidos referem-se ao sexo, idade gestacional ao nascimento (em semanas), idade gestacional corrigida na data da inserção do cateter, peso ao nascimento (em gramas), peso no dia da inserção, dias de vida na data do procedimento, sexo, 
diagnóstico do recém-nascido e indicação para uso do cateter PICC, exames prévios à inserção.

A Tabela 1 apresenta os dados referentes às características individuais dos recém-nascidos estudados. Dentre estas características, $(59,4 \%)$ eram do sexo masculino e a idade gestacional ao nascimento predominante foi menor ou igual a 32 semanas com (62,2\%), da mesma forma que a idade gestacional corrigida com (54,0\%), com diferença de apenas $8,2 \%$. Quanto ao peso ao nascimento, predominaram os recémnascidos menores ou iguais a 1.500 gramas $(64,9 \%)$, bem como o peso na data da inserção do cateter com $72,3 \%$. Os dias de vida dos recém-nascidos na inserção do cateter mostraram um índice de 48,7\%.

Isso mostra que os recém-nascidos estudados necessitaram de um acesso periférico central logo após seu nascimento. Os diagnósticos clínicos levantados no dia da inserção do cateter tiveram uma freqüência de 56,8\% nos recém-nascidos com a Síndrome do Desconforto Respiratório, ficando, em segundo lugar, os com Síndrome do Pulmão Úmido, com 29,7\%. A indicação principal para o uso do cateter PICC foi predominantemente à infusão da nutrição parenteral, com 94,6\%.

Tabela 1. Caracterização dos recém-nascidos submetidos ao procedimento de inserção do PICC. Berçário Anexo à Maternidade do HCFMUSP São Paulo, 2006. ( $N=37)$

\begin{tabular}{lcc}
\hline VARIÁVEIS & $\boldsymbol{N}$ & $\%$ \\
\hline Sexo & & \\
$\quad$ Masculino & 22 & 59,4 \\
$\quad$ Feminino & 15 & 40,6 \\
Idade Gestacional ao nascimento & & \\
$\quad \leq 32$ semanas & 23 & 62,2 \\
$\quad>32$ semanas & 14 & 37,8 \\
Peso ao nascimento & & \\
$\quad \leq 1.500 \mathrm{~g}$ & 24 & 64,9 \\
$\quad$ >1.500g & 13 & 35,1 \\
Dias de vida na data do procedimento & & \\
$\quad$ Um a Três & 18 & 48,7 \\
$\quad$ Quatro a Sete & 14 & 37,8 \\
\hline
\end{tabular}




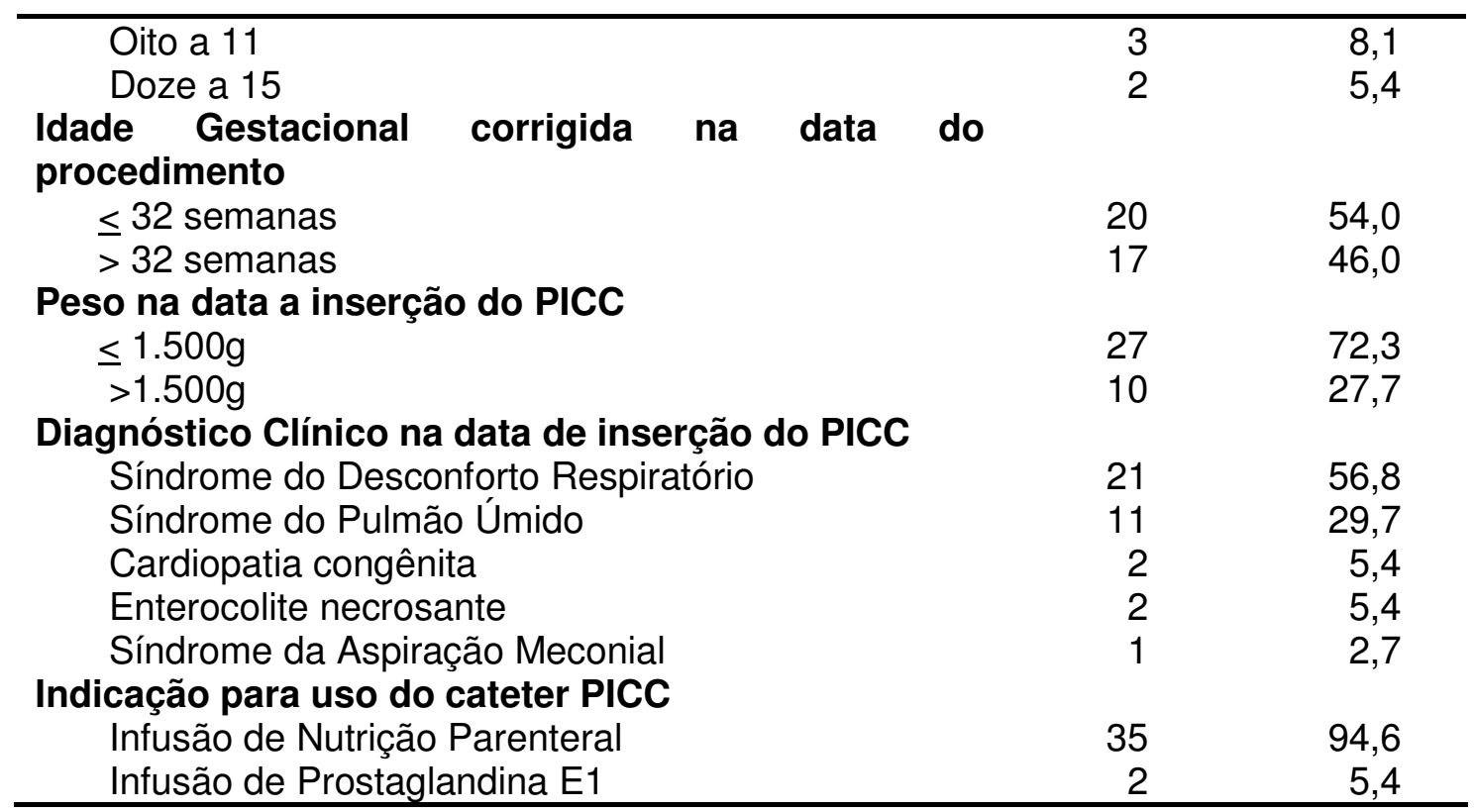

Tabela 2. Medidas descritivas das variáveis de caracterização dos recém-nascidos submetidos à implantação PICC. Berçário Anexo à Maternidade do HCFMUSP. São Paulo, 2006. ( $\mathrm{N}=37$ )

\begin{tabular}{lcccccc}
\hline Variável & Média & Mediana & Moda & $\begin{array}{c}\text { Valor } \\
\text { Máximo }\end{array}$ & $\begin{array}{c}\text { Valor } \\
\text { Mínimo }\end{array}$ & $\begin{array}{c}\text { Desvio } \\
\text { Padrão }\end{array}$ \\
\hline IG ao nascimento & 31,6 & 31,4 & 27,8 & 39,8 & 25,8 & 3,6 \\
IG corrigida & 32,2 & 33,0 & 34,0 & 40,0 & 26,0 & 3,8 \\
Peso no nascimento & $1.360,6$ & $1.250,0$ & $1.000,0$ & $2.910,0$ & 530,0 & 561,8 \\
Peso no procedimento & $1.289,2$ & $1.200,0$ & $1.040,0$ & $2.570,0$ & 525,0 & 541,5 \\
Idade cronológica & 4,3 & 4,0 & 2,0 & 15,0 & 1,0 & 3,1 \\
\hline
\end{tabular}

Nos dados da Tabela 2, conforme mostra a análise estatística descritiva, a idade gestacional ao nascimento e a idade gestacional corrigida mostraram médias homogêneas, com 31,6 e 32,2 semanas, respectivamente. Os valores da mediana, também, ficaram entre 31,4 e 33,0 semanas. Os pesos de nascimento em comparação com o peso na data do procedimento, também, tiveram médias e medianas muito próximas, com diferença em 71,4 gramas. A idade na data do procedimento teve uma média de 4,3 dias, com mediana de quatro dias e um desvio-padrão de 3,1dias. A análise permite mostrar que, mesmo com um valor máximo de 15 dias e um mínimo de um dia, ainda assim essa variável manteve-se com valores aproximados na população estudada. 
Tabela 3. Resultado da hemocultura antes da inserção do PICC. Berçário Anexo à Maternidade do HCFMUSP. São Paulo, 2006. ( $N=37)$

\begin{tabular}{lcc}
\hline Resultado da hemocultura antes do procedimento & $\mathbf{N}$ & $\%$ \\
\hline Negativo & 22 & 59,4 \\
Positivo & 15 & 40,6 \\
\hline TOTAL & 37 & 100,0 \\
\hline
\end{tabular}

Tabela 4. Resultado do exame Proteína $C$ reativa de recém-nascidos com hemocultura positiva antes da inserção do cateter PICC. Berçário Anexo à Maternidade do HCFMUSP. São Paulo, 2006. (N=15)

\begin{tabular}{lcc}
\hline Resultado do exame de Proteína C Reativa & $\boldsymbol{N}$ & $\%$ \\
\hline$>1 \mathrm{mg} / \mathrm{dl}$ & 11 & 73,4 \\
$\leq 1 \mathrm{mg} / \mathrm{dl}$ & 04 & 26,6 \\
\hline TOTAL & 15 & 100,0 \\
\hline
\end{tabular}

Os exames prévios levantados para inserção do cateter PICC foram: hemocultura, Proteína $C$ reativa $(P C R)$, plaquetas e hematócrito. Todos estes exames serviram de marcadores para possíveis condutas, antes da inserção do cateter PICC. Os dados da Tabela 3, 4 apresentaram se o recém-nascido antes da inserção do cateter já estava com algum foco infeccioso. Os recém-nascidos $(59,4 \%)$ que participaram do estudo tinham hemocultura negativa. O PCR avaliado nos recém-nascidos com hemocultura positiva teve uma porcentagem de $(73,4 \%)$ com resultados maiores que $1 \mathrm{mg} / \mathrm{dl}$.

Tabela 5. Resultado do hematócrito antes da inserção do PICC. Berçário Anexo à Maternidade do HCFMUSP. São Paulo, 2006.

\begin{tabular}{lcc}
\hline Resultado do hematócrito antes da inserção do PICC & $\mathbf{N}$ & $\%$ \\
\hline$<50 \%$ & 22 & 59,4 \\
$\geq 50 \%$ & 15 & 40,6 \\
\hline TOTAL & 37 & 100,0 \\
\hline
\end{tabular}

Os dados da Tabela 5 mostram que 22 (59,4\%) recém-nascidos apresentaram valores de hematócrito $(\mathrm{Ht})$ menores que $50 \%$, revelando valores adequados para o período neonatal. Considera-se normal o valor de hematócrito inferior a $60 \%$, entre $50 \%$ e $55 \%$.

A taxa de plaquetas foi um dos indicadores utilizados como marcador para indicar ou restringir o uso do cateter PICC nos recémnascidos. 
A contagem de plaquetas apresentava valores superiores a $150.000 \mathrm{U} / \mathrm{mm}^{3}$ em todos os recém-nascidos.

\subsection{Inserção do PICC}

Com relação à inserção do cateter PICC, foram levantados dados relativos ao: uso de fármaco para alívio da dor antes do procedimento, tipo de cateter; freqüência de punções realizadas; freqüência cardíaca e saturação de oxigênio dos recém-nascidos antes e após as punções; segmento corporal puncionado, veia puncionada e introdução do cateter, intercorrências durante o procedimento e solução infundida pelo cateter PICC.

O uso de fármacos para submeter o recém-nascido ao procedimento de inserção do PICC restringiu-se à administração do sedativo Midazolam, na dose de $0,1 \mathrm{mg} / \mathrm{Kg}$ antes do início do procedimento de inserção do PICC. A prescrição de sedativo não é um procedimento protocolar, adotado rotineiramente, conforme mostram os dados da Tabela 6. Uso de fármacos analgésicos, antes do procedimento, não foi verificado nos 37 recém-nascidos submetidos ao procedimento de inserção do PICC.

Tabela 6. Uso de fármaco sedativo pré-inserção do cateter PICC. Berçário Anexo à Maternidade do HCFMUSP. São Paulo, 2006.

\begin{tabular}{lcc}
\hline Uso de fármaco sedativo & $\mathbf{N}$ & $\%$ \\
\hline Não & 33 & 89,2 \\
Sim & 4 & 10,8 \\
\hline TOTAL & 37 & 100,0 \\
\hline
\end{tabular}

Dos trinta e sete recém-nascidos, apenas quatro (10,8\%) receberam Midazolam.

Tabela 7. Tipo de cateter PICC utilizado. Berçário Anexo à Maternidade do HCFMUSP. São Paulo, 2006.

N \%




\begin{tabular}{lcc}
\hline Silicone & 2 & 5,4 \\
\hline TOTAL & 37 & 100,0 \\
\hline
\end{tabular}

Os dados da Tabela 7 mostram que o cateter PICC de poliuretano foi o mais utilizado no grupo de recém-nascidos estudados, 35 (94,6\%). Todos os cateteres eram calibre 2 French com o comprimento, variando de 48 a 50, indicado para uso em recém-nascidos.

Tabela 8. Medidas descritivas da freqüência de punções venosas na inserção do PICC. Berçário Anexo à Maternidade do HCFMUSP. São Paulo, 2006. $(\mathrm{N}=37)$

\begin{tabular}{cccccc}
\hline Média & Mediana & Moda & Máximo & Mínimo & DP \\
\hline 3,4 & 3,0 & 2,0 & 9,0 & 1,0 & 2,2 \\
\hline
\end{tabular}

A média da freqüência de punção venosa na população estudada foi de 3,4 com valor mínimo de um e máximo de nove punções. O valor da média correspondeu às recomendações da literatura e é o que se adota no serviço onde este estudo foi realizado.

Tabela 9. Freqüência de sucesso na inserção do PICC, segundo ordem seqüencial das punções venosas realizadas. Berçário Anexo à Maternidade do HCFMUSP. São Paulo, 2006. ( $N=37)$

\begin{tabular}{|c|c|c|c|c|}
\hline \multirow{3}{*}{$\begin{array}{l}\text { Ordem } \\
\text { seqüencial } \\
\text { das punções }\end{array}$} & \multicolumn{4}{|c|}{ Sucesso na inserção do PICC } \\
\hline & \multicolumn{2}{|c|}{ SIM } & \multicolumn{2}{|c|}{ Não } \\
\hline & $\mathrm{N}$ & $\%$ & $\mathrm{~N}$ & $\%$ \\
\hline $1^{\mathrm{a}}(\mathrm{N}=37)$ & 8 & 21,6 & 29 & 78,4 \\
\hline $2^{-\underline{a}} \quad(N=29)$ & 9 & 31,0 & 20 & 69,0 \\
\hline $3^{-a} \quad(N=19)$ & 2 & 10,5 & 17 & 89,5 \\
\hline $4^{-\mathrm{a}} \quad(\mathrm{N}=17)$ & 4 & 23,5 & 13 & 76,5 \\
\hline $5^{\mathrm{a}} \quad(\mathrm{N}=12)$ & 2 & 20,0 & 8 & 80,0 \\
\hline $6^{-a} \quad(N=8)$ & 1 & 12,5 & 7 & 87,5 \\
\hline $7^{\mathrm{a}} \quad(\mathrm{N}=4)$ & 0 & 0 & 4 & 100 \\
\hline $8^{\mathrm{a}}(\mathrm{N}=2)$ & 1 & 50,0 & 1 & 50,0 \\
\hline $9^{a} \quad(N=1)$ & 0 & 0 & 1 & 100 \\
\hline
\end{tabular}


Pelos dados da Tabela 9, verifica-se que o porcentual de sucesso na inserção do PICC na primeira punção venosa foi de 21,6\%. Foram submetidos a segunda punção venosa, 29 recém-nascidos, dos quais, nove $(31,0 \%)$ obtiveram sucesso na inserção do cateter.

Dos (20) recém-nascidos em que a segunda punção venosa resultou em insucesso, (1) foi interrompido o procedimento, os outros (19) neonatos foram submetidos a terceira punção. $\mathrm{Na}$ terceira punção, a freqüência porcentual de sucesso na inserção do PICC foi $10,5 \%$, correspondendo a dois recém-nascidos. Foram submetidos a quarta punção, (17) recém-nascidos com freqüência de sucesso de 23,5\% (quatro neonatos), vale salientar que três neonatos não foram mais submetidos a punções. Assim, dez recém-nascidos foram submetidos a quinta punção. Foram submetidos a sexta punção, oito recém-nascidos com freqüência de sucesso de $25,0 \%$ (um neonato). Na sétima punção, participaram quatro recém-nascidos e nas oitava e nona (um neonato). Dos 37 (100\%) recémnascidos incluídos no estudo, a inserção do PICC deu-se em 27 (72,9\%) neonatos.

Tabela 10. Medidas descritivas da freqüência cardíaca pré e pós-punção. Berçário Anexo à Maternidade do HCFMUSP. São Paulo, 2006.

\begin{tabular}{|c|c|c|c|c|c|c|c|c|c|c|c|c|}
\hline \multirow{2}{*}{$\begin{array}{l}\text { Seqüência } \\
\text { de } \\
\text { punções }\end{array}$} & \multicolumn{2}{|c|}{ Média } & \multicolumn{2}{|c|}{ Mediana } & \multicolumn{2}{|c|}{ Moda } & \multicolumn{2}{|c|}{ Máximo } & \multicolumn{2}{|c|}{ Mínimo } & \multicolumn{2}{|c|}{ 느 } \\
\hline & Pré & Pós & Pré & Pós & Pré & Pós & Pré & Pós & Pré & Pós & Pré & Pós \\
\hline $1^{\mathrm{a}}(\mathrm{N}=37)$ & 161,0 & 161,3 & 160,0 & 164,0 & 154,0 & 168,0 & 198,0 & 195,0 & 121,0 & 124,0 & 18,9 & \\
\hline & & & & & & & & & & & & \\
\hline & & & & & & & & & & & & \\
\hline & 1,4 & . & $\mathrm{I}_{1}$ & & 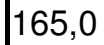 & & 20 & & 13 & & 18 & \\
\hline & 59,2 & 157,2 & 16 & 15 & 6,0 & & 186,0 & 18 & 12 & & 20 & 19,5 \\
\hline & 161,9 & 165 & 16 & 16 & 128,0 & & 194,0 & 19 & 12 & & 19 & 14 \\
\hline & & 177 & & & 15 & & & & & & 19 & 1 \\
\hline $8^{\mathrm{a}}(\mathrm{N}$ & & & & & 162,0 & 170 & 172,0 & 187,0 & 162 & 170 & 7,0 & 12,0 \\
\hline
\end{tabular}

Tabela 11. Medidas descritivas dos valores de saturação de oxigênio pré e pós-punção. Berçário Anexo à Maternidade do HC/FMUSP. 
São Paulo, 2006.

\begin{tabular}{|c|c|c|c|c|c|c|c|c|c|c|c|c|}
\hline \multirow{2}{*}{$\begin{array}{l}\text { Seqüência } \\
\text { de punções }\end{array}$} & \multicolumn{2}{|c|}{ Média } & \multicolumn{2}{|c|}{ Mediana } & \multicolumn{2}{|c|}{ Moda } & \multicolumn{2}{|c|}{ Máximo } & \multicolumn{2}{|c|}{$\underline{\text { Mínimo }}$} & \multicolumn{2}{|c|}{$\underline{D P}$} \\
\hline & Pré & Pós & Pré & Pós & Pré & Pós & Pré & Pós & Pré & Pós & Pré & Pós \\
\hline $1^{\mathrm{a}}(\mathrm{N}=37)$ & 95,4 & 95,7 & 97,0 & 97,0 & 97,0 & 97,0 & 99,0 & 99,0 & 83,0 & 84,0 & 3,4 & 3,3 \\
\hline $2^{\mathrm{a}}(\mathrm{N}=29)$ & 95,9 & 95,5 & 97,0 & 96,0 & 97,0 & 97,0 & 100 & 99,0 & 84,0 & 86,0 & 3,3 & 3,2 \\
\hline $3^{\mathrm{a}}(\mathrm{N}=19)$ & 95,3 & 95,1 & 97,0 & 97,0 & 98,0 & 97,0 & 100 & 100 & 84,0 & 81,0 & 4,0 & 5,0 \\
\hline $4^{\mathrm{a}}(\mathrm{N}=17)$ & 95,2 & 95,1 & 97,0 & 97,0 & 98,0 & 98,0 & 99,0 & 98,0 & 84,0 & 84,0 & 3,9 & 3,9 \\
\hline $5^{\mathrm{a}}(\mathrm{N}=10)$ & 95,2 & 95,4 & 96,5 & 95,4 & 98,0 & 96,0 & 99,0 & 98,0 & 84,0 & 84,0 & 4,4 & 4,2 \\
\hline $6^{\mathrm{a}}(\mathrm{N}=8)$ & 95,0 & 93,7 & 96,5 & 95,0 & 96,0 & 94,0 & 99,0 & 98,0 & 83,0 & 82,0 & 5,1 & 5,0 \\
\hline $7^{\mathrm{a}}(\mathrm{N}=4)$ & 93,0 & 93,2 & 94,0 & 95,0 & 86,0 & 86,0 & 98,0 & 97,0 & 86,0 & 86,0 & 5,3 & 4,9 \\
\hline $8^{a}(\mathrm{~N}=2)$ & 94,5 & 96,0 & 94,5 & 96,0 & 93,0 & 95,0 & 96,0 & 97,0 & 93,0 & 95,0 & 2,1 & 1,4 \\
\hline
\end{tabular}

Tanto a freqüência cardíaca como a saturação de oxigênio foram valores obtidos por monitorização eletrônica (DX 2010-LCD-Dixtal Biomédica $\left.{ }^{\circledR}\right)$.

Pelos dados das Tabelas 10 e 11, verifica-se que as médias mantiveram valores fisiológicos. Na oitava punção, houve um discreto aumento na média da freqüência cardíaca pós-punção comparado à média da primeira punção, mas, ainda, dentro de parâmetros fisiológicos.

Tanto a média como a mediana dos valores da saturação de oxigênio pré e pós-punção mantiveram-se acima de 95\%, mostrando que o procedimento de punção venosa não alterou os valores de saturação de oxigênio, indicando que as punções venosas e a inserção do cateter não causaram instabilidade nos parâmetros vitais dos neonatos.

Chama a atenção o recém-nascido submetido a nove punções venosas, embora tenha sido manipulado e submetido ao procedimento, os valores de saturação de oxigênio pré e pós-punção mantiveram-se dentro dos parâmetros fisiológicos.

Tabela 12. Segmento corporal e veia puncionada para inserir o PICC segundo a ordem seqüencial das punções. Berçário Anexo à Maternidade do HCFMUSP. São Paulo, 2006. ( $\mathrm{N}=127)$

\begin{tabular}{|c|c|c|c|c|c|c|c|c|c|c|c|c|c|c|}
\hline \multirow{3}{*}{$\begin{array}{l}\text { Segmento } \\
\text { Corporal } \\
\text { Veia }\end{array}$} & \multicolumn{14}{|c|}{ Ordem seqüencial das punções } \\
\hline & \multicolumn{2}{|r|}{$1^{\mathrm{a}}$} & \multicolumn{2}{|c|}{$2^{\mathbf{a}}$} & \multicolumn{2}{|c|}{$3^{\mathbf{a}}$} & \multicolumn{2}{|c|}{$4^{\mathbf{a}}$} & \multicolumn{2}{|c|}{$5^{\mathbf{a}}$} & \multicolumn{2}{|c|}{$6^{\mathbf{a}}$} & \multicolumn{2}{|c|}{$7^{\text {a }}$} \\
\hline & $\mathrm{N}$ & $\%$ & $\mathrm{~N}$ & $\%$ & $\mathrm{~N}$ & $\%$ & $\mathrm{~N}$ & $\%$ & $\mathrm{~N}$ & $\%$ & $\mathrm{~N}$ & $\%$ & $\mathrm{~N}$ & $\%$ \\
\hline MSD & & & & & & & & & & & & & & \\
\hline Basílica & 20 & 54,1 & 8 & 27,6 & 5 & 26,3 & 4 & 23,6 & 1 & 10,0 & - & - & - & . \\
\hline
\end{tabular}




\begin{tabular}{|c|c|c|c|c|c|c|c|c|c|c|c|c|c|c|}
\hline Cefálica & 9 & 24,3 & 9 & 31,0 & 7 & 36,8 & 3 & 17,7 & 1 & 10,0 & - & - & - & - \\
\hline Cubital & 1 & 2,7 & 7 & 24,1 & 2 & 10,5 & 2 & 11,7 & 4 & 40,0 & 1 & 12,5 & - & - \\
\hline Arc.dorsal & 1 & 2,7 & - & - & 2 & 10,5 & 1 & 5,9 & - & - & - & - & - & - \\
\hline $\begin{array}{l}\text { Axilar } \\
\text { MSE }\end{array}$ & - & - & - & - & - & - & 1 & 5,9 & - & - & - & - & - & - \\
\hline Basílica & 1 & 2,7 & 3 & 10,3 & 1 & 5,3 & 1 & 5,9 & 2 & 20,0 & 2 & 25,0 & 1 & 25,0 \\
\hline Cefálica & 1 & 2,7 & 1 & 3,5 & 1 & 5,3 & 1 & 5,9 & - & - & - & - & - & - \\
\hline Cubital & 1 & 2,7 & - & - & 1 & 5,3 & 2 & 11,7 & - & - & 1 & 12,5 & 1 & 25,0 \\
\hline $\begin{array}{l}\text { Arc. dorsal } \\
\text { Céfalo } \\
\text { cervical }\end{array}$ & 1 & 2,7 & - & - & - & - & - & - & - & - & 1 & 12,5 & 1 & 25,0 \\
\hline Auric. post & - & - & - & - & - & - & - & - & - & - & 2 & 25,0 & - & - \\
\hline Temporal & - & - & - & - & - & - & - & - & 1 & 10,0 & - & - & 1 & 25,0 \\
\hline Jugular ext.D & 2 & 5,4 & 1 & 3,5 & - & - & 2 & 11,7 & 1 & 10,0 & 1 & 12,5 & - & - \\
\hline TOTAL & 37 & 100 & 29 & 100 & 19 & 100 & 17 & 100 & 10 & 100 & 8 & 100 & 4 & 100 \\
\hline
\end{tabular}

Dois neonatos foram submetidos a 8aㅡ punção venosa em veia cefálica de MSE, um neonato foi submetido a 9å punção em veia cefálica de MSE

Os dados apresentados na Tabela 12 mostram que foram realizadas até nove punções para inserir o PICC, totalizando 127 punções realizadas nos 37 recém-nascidos que participaram do estudo.

O membro superior direito (MSD) foi o segmento de escolha dos profissionais para instalar o PICC, sendo a veia basílica a mais puncionada, 20 $(54,1 \%)$ recém-nascidos. A segunda mais puncionada foi a veia cefálica de MSD, $24,3 \%$. No membro superior esquerdo (MSE), as veias preferenciais para acesso foram a basílica e a cefálica. O segmento cefalocervical foi pouco puncionado, sendo a veia jugular externa direita a mais acessada.

Tabela 13. Veias puncionadas para inserir o PICC. Berçário Anexo à Maternidade do HCFMUSP. São Paulo, 2006.

\begin{tabular}{lcc}
\hline Veias puncionadas & $\boldsymbol{N}$ & $\%$ \\
\hline Basílica do MSD & 38 & 29,9 \\
Cefálica do MSD & 29 & 22,8 \\
Cubital do MSD & 17 & 13,4 \\
Basílica do MSE & 11 & 8,7 \\
Cefálica do MSE & 7 & 5,5 \\
Jugular externa direita & 7 & 5,5 \\
Cubital do MSE & 6 & 4,7 \\
Arcos dorsais da mão direita & 4 & 3,1 \\
Arcos dorsais da mão esquerda & 3 & 2,4 \\
Auricular posterior direita & 2 & 1,6 \\
Temporal direita & 2 & 1,6 \\
Axilar do MSD & 1 & 0,8 \\
\hline TOTAL & 127 & 100 \\
\hline
\end{tabular}


Os dados da Tabela 13 complementam os da Tabela 12. Das 127 punções, $38(29,9 \%)$ foram realizadas na veia basílica de MSD, seguida da veia cefálica $29(22,8 \%)$ punções. Em MSE, foram 11 (8,7\%) punções na veia basílica e sete $(5,5 \%)$ em veia cefálica.

Tabela 14. Motivos de insucesso nas primeiras quatro punções venosas para inserção do PICC. Berçário Anexo à Maternidade do HCFMUSP. São Paulo, 2006.

\begin{tabular}{|c|c|c|c|c|c|c|c|c|}
\hline \multirow{2}{*}{$\begin{array}{l}\text { Motivos de insucesso } \\
\text { na inserção }\end{array}$} & \multicolumn{2}{|c|}{$\begin{array}{c}\text { 1- Punção }^{\text {a Puna }} \\
\text { (N=37) }\end{array}$} & \multicolumn{2}{|c|}{$\begin{array}{c}\text { 2ª Punção }^{\text {a }} \\
\text { (N=29) }\end{array}$} & \multicolumn{2}{|c|}{$\begin{array}{c}\text { 3aPunção } \\
\text { (N=19) }\end{array}$} & \multicolumn{2}{|c|}{$\begin{array}{c}4^{\text {a }} \text { Punção } \\
\text { (N=17) }\end{array}$} \\
\hline & $\mathbf{N}$ & $\%$ & $\mathbf{N}$ & $\%$ & $\mathbf{N}$ & $\%$ & $\mathbf{N}$ & $\%$ \\
\hline Fragilidade vascular & 16 & 43,2 & 15 & 51,7 & 11 & 57,9 & 11 & 64,7 \\
\hline Transfixação da veia & 11 & 29,7 & 3 & 44,8 & 11 & 57,9 & 6 & 35,3 \\
\hline Agitação do RN & 9 & 24,3 & 8 & 27,6 & 8 & 42,1 & 6 & 35,3 \\
\hline Fechamento de válvula & 12 & 32,4 & 5 & 17,2 & 5 & 26,3 & 2 & 11,8 \\
\hline Hematoma & 8 & 21,6 & 10 & 34,5 & 9 & 47,4 & 7 & 41,2 \\
\hline Oclusão do introdutor & 6 & 16,2 & 4 & 13,8 & 5 & 26,3 & 1 & 5,9 \\
\hline
\end{tabular}




\begin{tabular}{|c|c|c|c|c|c|c|c|c|}
\hline Ponta mal posicionada & 1 & 2,7 & 4 & 13,8 & 1 & 5,2 & - & - \\
\hline $\begin{array}{l}\text { Dificuldade de visualizar } \\
\text { rede venosa }\end{array}$ & 1 & 2,7 & 1 & 3,4 & - & - & 1 & 5,9 \\
\hline Espasmo vascular & 1 & 2,7 & - & - & - & - & - & - \\
\hline $\begin{array}{l}\text { Extração acidental do } \\
\text { introdutor }\end{array}$ & 1 & 2,7 & - & - & - & - & - & - \\
\hline Punção arterial & 1 & 2,7 & - & - & - & - & - & - \\
\hline $\begin{array}{l}\text { Medida Inadequada } \\
\text { do cateter }\end{array}$ & 1 & 2,7 & - & - & 1 & 5,2 & - & - \\
\hline
\end{tabular}

Tabela 15. Motivos de insucesso da quinta a oitava punção venosa para inserção do PICC. Berçário Anexo à Maternidade do HCFMUSP São Paulo, 2006.

\begin{tabular}{|c|c|c|c|c|c|c|c|c|}
\hline \multirow[t]{2}{*}{ Motivos de insucesso } & \multicolumn{2}{|c|}{$\begin{array}{c}\text { 5a Punção }^{\text {a Puncio }} \\
(\mathrm{N}=10\end{array}$} & \multicolumn{2}{|c|}{$\begin{array}{c}\text { 6- Punção } \\
(\mathrm{N}=8)\end{array}$} & \multicolumn{2}{|c|}{$\begin{array}{c}7^{\text {a }} \text { Punção } \\
(\mathrm{N}=4)\end{array}$} & \multicolumn{2}{|c|}{$\begin{array}{c}\text { 8' Punção }^{\text {Pance }} \\
(\mathrm{N}=2\end{array}$} \\
\hline & $\mathbf{N}$ & $\%$ & $\mathbf{N}$ & $\%$ & $\mathbf{N}$ & $\%$ & $\mathbf{N}$ & $\%$ \\
\hline Fragilidade & 7 & 70,0 & 5 & 62,5 & 3 & 75,0 & 1 & 50,0 \\
\hline Transfixação & 4 & 40,0 & 4 & 50,0 & 3 & 75,0 & 1 & 50,0 \\
\hline Agitação do recém-nascido & 1 & 10,0 & 3 & 37,5 & 3 & 75,0 & 1 & 50,0 \\
\hline Válvula vascular fechada & 2 & 20,0 & 2 & 25,0 & 1 & 25,0 & - & - \\
\hline Hematoma & 6 & 60,0 & 3 & 37,5 & 3 & 75,0 & 1 & 50,0 \\
\hline Punção arterial & 1 & 10,0 & - & - & - & - & - & - \\
\hline
\end{tabular}

Os dados verificados nas Tabelas 14 e 15 mostram que a fragilidade vascular foi o motivo de insucesso mais freqüente na inserção do cateter PICC em todas as tentativas de punção realizadas. A transfixação da veia foi o segundo motivo de ocorrência de insucesso com freqüência de 11 (29,7\%)

casos observados na primeira punção, $13(44,8 \%)$, na segunda punção e três $(75,0 \%)$ na sétima punção.

Como conseqüência da transfixação da veia, ocorreu hematoma local, que foi a intercorrência verificada em todas as seqüências das punções, em oito $(21,6 \%)$ recém-nascidos na primeira punção, dez $(34,5 \%)$ na segunda e três $(75,0 \%)$ na sétima punção.

A agitação do recém-nascido foi observada em todas as punções, sendo o terceiro motivo mais freqüente de insucesso, nove $(24,3 \%)$ 
neonatos na primeira punção, oito $(42,1 \%)$ na terceira e três $(75,0 \%)$ na sétima.

Outro motivo de insucesso foi o fechamento da válvula vascular verificado em $12(32,4 \%)$ das primeiras punções.

A oclusão do introdutor ocorreu nas quatro primeiras punções, ocorrência verificada em seis $(16,2 \%)$ casos de primeira punção e na terceira punção cinco $(26,3 \%)$ casos.

Os motivos de insucesso do único recém-nascido submetido a nove punções venosas foram: fragilidade vascular, transfixação venosa e agitação do recém-nascido, o que impediu a instalação do cateter PICC.

Os demais motivos de insucesso permaneceram abaixo de 50,0\%.

Tabela 16. Intercorrências na inserção do PICC observadas nas quatro primeiras punções venosas. Berçário Anexo à Maternidade do HCFMUSP. São Paulo, 2006.

\begin{tabular}{|c|c|c|c|c|c|c|c|c|}
\hline \multirow{2}{*}{$\begin{array}{l}\text { Intercorrências na } \\
\text { inserção } \\
\text { do cateter }\end{array}$} & \multicolumn{2}{|c|}{$\begin{array}{l}\text { 1' Punção } \\
\text { (N=37) }\end{array}$} & \multicolumn{2}{|c|}{$\begin{array}{l}\text { 2.Punção } \\
\text { (N=29) }\end{array}$} & \multicolumn{4}{|c|}{$\begin{array}{c}\text { 3aPunção } \\
\text { (N=19) }\end{array} \quad \begin{array}{c}\text { Punção } \\
(\mathrm{N}=17)\end{array}$} \\
\hline & $\mathbf{N}$ & $\%$ & $\mathbf{N}$ & $\%$ & $\mathbf{N}$ & $\%$ & $\mathbf{N}$ & $\%$ \\
\hline $\begin{array}{l}\text { Alteração na viscosidade } \\
\text { sangüínea }\end{array}$ & 4 & 10,8 & 9 & 31,0 & 5 & 26,3 & 5 & 29,4 \\
\hline Taquicardia & 2 & 5,4 & - & - & 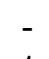 & - & 1 & 5,8 \\
\hline Queda de saturação do oxigên & 1 & 07 & - & - & 1 & 5,7 & - & - \\
\hline Mioclonia & 1 & 2,7 & - & - & & & - & - \\
\hline
\end{tabular}

Tabela 17. Motivos de intercorrência da quinta a sétima punções venosas no procedimento de inserção do PICC. Berçário Anexo à Maternidade do HCFMUSP. São Paulo, 2006.

\begin{tabular}{|c|c|c|c|c|c|c|}
\hline \multirow{2}{*}{$\begin{array}{l}\text { Intercorrências na } \\
\text { inserção } \\
\text { do cateter }\end{array}$} & \multicolumn{2}{|c|}{$\begin{array}{c}5^{\text {a Punção }} \\
(\mathrm{N}=10)\end{array}$} & \multicolumn{2}{|c|}{$\begin{array}{c}\text { 6- Punção } \\
(\mathrm{N}=8)\end{array}$} & \multicolumn{2}{|c|}{$\begin{array}{c}7^{\text {a Punção }} \\
(\mathrm{N}=4)\end{array}$} \\
\hline & $\mathbf{N}$ & $\%$ & $\mathbf{N}$ & $\%$ & $\mathbf{N}$ & $\%$ \\
\hline $\begin{array}{l}\text { Alteração da viscosidade } \\
\text { sangüínea }\end{array}$ & 1 & 10,0 & 1 & 12,5 & 1 & 25,0 \\
\hline Taquicardia & - & - & 1 & 12,5 & - & - \\
\hline
\end{tabular}

* Nenhum dos dois recém-nascidos submetidos a 8a punção venosa apresentou intercorrências na inserção do PICC. O único neonato submetido a nove punções apresentou só a taquicardia como intercorrência. 
As Tabelas 16 e 17 mostram que, em todas as punções venosas, a alteração da viscosidade sangüínea foi verificada, sendo a maior freqüência porcentual verificada na terceira punção, nove $(31,0 \%)$ casos.

A taquicardia foi observada em quatro procedimentos de inserção do PICC, sendo a segunda mais freqüente intercorrência. Para avaliar o aumento da freqüência cardíaca (FC), foi verificada a FC do recém-nascido antes de submetê-lo à punção venosa. Durante a punção venosa, verificouse que a FC aumentou em mais de 25 batimentos por minuto. Utilizou-se a escala PIPP (Perfil de Dor no Prematuro) que analisa a dor aguda de RN pré-termo e que afere a FC, como um dos indicadores de dor. Por intermédio desse instrumento de avaliação de dor, foi possível detectar-se a taquicardia durante a inserção do cateter.

Tabela 18. Sucesso obtido na introdução do cateter PICC entre os recémnascidos submetidos ao procedimento. Berçário Anexo à Maternidade do HCFMUSP. São Paulo, 2006.

\begin{tabular}{ccc}
\hline Sucesso na introdução do PICC & $\mathbf{N}$ & $\%$ \\
\hline Sim & 27 & 72,3 \\
Não & 10 & 20,7 \\
\hline TOTAL & 37 & 100 \\
\hline
\end{tabular}

A prevalência de sucesso na introdução do cateter PICC foi de $72,3 \%$ (27 neonatos), conforme mostram os dados da Tabela 18.

Tabela 19. Local alojado pela ponta do cateter PICC pós-inserção visualizada pelos exames de radiografia de tórax. Berçário Anexo à Maternidade do HCFMUSP. São Paulo, 2006. ( $\mathrm{N}=27)$

\begin{tabular}{lcc}
\hline Local alojado pela ponta do PICC pós-inserção & $\boldsymbol{N}$ & $\%$ \\
\hline Átrio Direito & 13 & 48,2 \\
Veia cava superior & 7 & 25,9 \\
Veia axilar ou veia inominada & 4 & 14,8 \\
Veia Jugular & 3 & 11,1 \\
\hline TOTAL & 27 & 100 \\
\hline
\end{tabular}

Os dados da Tabela 19 mostram que a ponta do cateter visualizada pelos exames de radiografia de tórax alojou-se com maior freqüência 13 
(48,2\%), dentro da câmara cardíaca, no átrio direito, ultrapassando a veia cava superior. Estes casos foram tratados com manobras de tração para reposicionar a ponta do cateter na veia cava superior. Dos 27 cateteres inseridos, em quatro $(14,8 \%)$, as pontas alojaram-se na região periférica (veia axilar ou veia inominada). Em três $(11,1 \%$ ) casos, a ponta alojou-se fora do local planejado, fazendo um falso trajeto e alojando sua ponta na veia jugular, o que justificou a remoção do cateter.

Tabela 20. Distribuição dos recém-nascidos submetidos à tração do cateter PICC para reposicionamento da ponta. Berçário Anexo à Maternidade do HCFMUSP. São Paulo, 2006. $(\mathrm{N}=24)$

\begin{tabular}{lcc}
\hline Tração do cateter & $\mathbf{N}$ & $\%$ \\
\hline Sim & 13 & 54,2 \\
Não & 11 & 45,8 \\
\hline TOTAL & 24 & 100 \\
\hline
\end{tabular}

Dos vinte e quatro recém-nascidos que mantiveram o cateter, 13 $(54,2 \%)$ foram submetidos à tração do cateter. Os dados indicam que a mensuração do comprimento do cateter realizada previamente à inserção não mostrou exatidão com a extensão do comprimento percorrido pelo cateter até a veia cava superior.

Tabela 21. Local alojado pela ponta do cateter PICC, após manobra de tração. Berçário Anexo à Maternidade do HCFMUSP. São Paulo, 2006. $(\mathrm{N}=13)$

\begin{tabular}{lcc}
\hline Localização da ponta do cateter pós-tração & N & $\%$ \\
\hline Terço inferior da veia cava superior & 9 & 69,2 \\
Terço médio da veia cava superior & 3 & 23,1 \\
Terço superior da veia cava superior & 1 & 7,7 \\
\hline TOTAL & 13 & 100 \\
\hline
\end{tabular}

Tabela 22. Posicionamento da ponta do cateter PICC no momento de fixação. 
$(\mathrm{N}=24)$

\begin{tabular}{lrr}
\hline Localização da ponta do cateter & N & $\%$ \\
\hline Central & 20 & 83,3 \\
Midline & 3 & 12,5 \\
Midclavicular & 1 & 4,2 \\
\hline TOTAL & 24 & 100 \\
\hline
\end{tabular}

Todos os cateteres tracionados tiveram as pontas reposicionadas e alojadas em veia cava superior. Nos dados da Tabela 21, verificou-se que o cateter mesmo alojado na veia cava superior apresentou diferentes posições, em nove $(69,2 \%)$ a ponta alojou-se no terço inferior da veia cava superior.

Pelos dados das Tabelas 21 e 22, verifica-se que $83,3 \%$ dos cateteres ficaram em posição central e 16,7\%, em posição periférica.

Tabela 23. Medidas descritivas do comprimento $(\mathrm{cm})$ do cateter introduzido, segundo o segmento puncionado. Berçário Anexo à Maternidade do HCFMUSP. São Paulo, 2006. ( $\mathrm{N}=24)$

\begin{tabular}{lccccccc}
\hline Segmento puncionado & $\mathrm{N}$ & Média & Mediana & Moda & Mínimo & Máximo & DP \\
\hline MSD & 13 & 11,4 & 12,0 & 12,0 & 9,0 & 14,0 & 1,5 \\
MSE & 7 & 13,5 & 13,5 & 13,5 & 10,0 & 16,5 & 1,9 \\
Cervical & 4 & 7,1 & 7,2 & 7,5 & 6,5 & 7,5 & 0,4 \\
\hline
\end{tabular}

A média do comprimento do cateter inserido em MSD foi de 11,4 cm e mediana de $12,0 \mathrm{~cm}$. Em MSE, a média ficou em $13,5 \mathrm{~cm}$. O valor máximo do comprimento foi 16,5 . Nos cateteres inseridos na região cervical, a média da extensão do cateter inserido foi $7,1 \mathrm{~cm}$, com um mínimo de $6,5 \mathrm{~cm}$.

Tabela 24. Realização de exame ecocardiográfico pós-inserção do cateter. Berçário Anexo à Maternidade do HCFMUSP. São Paulo, 2006. $(\mathrm{N}=24)$

\begin{tabular}{lcc}
\hline Exame ecocardiográfico pós-inserção do cateter & $\mathbf{N}$ & $\%$ \\
\hline Não & 16 & 66,7 \\
Sim & 8 & 33,3 \\
\hline TOTAL & 24 & 100 \\
\hline
\end{tabular}

Tabela 25. Posicionamento da ponta do cateter PICC visualizado pelo ecocardiograma. Berçário Anexo à Maternidade do HCFMUSP. São Paulo, 2006. $(\mathrm{N}=8)$ 


\begin{tabular}{lcc}
\hline Veia cava superior & 7 & 87,5 \\
Veia inominada & 1 & 12,5 \\
\hline TOTAL & 8 & 100 \\
\hline
\end{tabular}

O exame ecocardiográfico não é parte do protocolo do serviço para confirmar o local de alojamento da ponta do cateter PICC, foi solicitado como exame complementar para avaliação clínica do neonato, o que justifica a realização do exame por apenas oito (33,3\%) dos recém-nascidos, permitindo identificar que a ponta do cateter estava alojada em veia cava superior de sete $(87,5 \%)$ neonatos.

Tabela 26. Medidas descritivas do tempo (em minutos) entre inserção do PICC e o primeiro exame de radiografia de tórax e tração do cateter até a segunda radiografia. Berçário Anexo à Maternidade do HCFMUSP São Paulo, 2006.

\begin{tabular}{l|ccccccc}
\hline $\begin{array}{l}\text { Tempo decorrido em } \\
\text { Minutos }\end{array}$ & N & Média & Mediana & Moda & Mínimo & Máximo & DP \\
\hline Inserção do cateter ao 1ํ RX & 27 & 98,1 & 120,0 & 120,0 & 10,0 & 180,0 & 42,8 \\
Tração do cateter ao 2ํำ RX & 13 & 53,0 & 30,0 & 30,0 & 30,0 & 120,0 & 32,7 \\
\hline
\end{tabular}

Os dados da Tabela 26 mostram que o tempo decorrido entre a inserção do PICC e confirmação da localização da ponta do cateter pelo exame radiológico é bastante variável, no mínimo 10 minutos e máximo 180 minutos, média de 98 minutos. Na instituição campo de estudo, é necessário aguardar o técnico da radiologia, uma vez que não se dispõe de profissional e equipamento exclusivos para atender à Unidade Neonatal. Esta variação no tempo, também pode ser justificada pela freqüência maior de inserção de cateteres PICC ter ocorrido no período noturno, quando o serviço de radiologia conta com quadro menor para realização do segundo exame radiológico, solicitado nos casos onde houve necessidade de tracionar o cateter para reposicionar a ponta em veia cava superior. O tempo médio foi de 53 minutos. Em função desta limitação, o horário para realizar o procedimento de inserção do cateter foi restrito para ocorrer, preferencialmente, nos períodos diurno e vespertino.

\subsection{Manutenção do PICC}


A manutenção do cateter refere-se ao curativo realizado no local da inserção do cateter, identificação e acompanhamento de sinais precoce de infecção, infiltração e outras intercorrências relacionadas à permeabilidade venosa e infusão de soluções prescritas.

Tabela 27. Solução infundida pelo PICC imediatamente após a fixação do cateter. Berçário Anexo à Maternidade do HCFMUSP. São Paulo, 2006. $(\mathrm{N}=24)$

\begin{tabular}{|c|c|c|}
\hline \multicolumn{3}{|c|}{ Solução Infundida } \\
\hline & $\mathbf{N}$ & $\%$ \\
\hline Nutrição Parenteral Total & 23 & 95,8 \\
\hline Antibióticos & 15 & 62,5 \\
\hline Prostaglandina E1 & 1 & 4,2 \\
\hline
\end{tabular}

Dos vinte e quatro recém-nascidos submetidos ao procedimento de inserção do cateter PICC, a maioria 23(95,8\%), recebeu Nutrição Parenteral Total (NPT), após a instalação do PICC. Nesta instituição, o PICC não é uma via exclusiva para infusão de nutrição parenteral contínua, infunde-se antibióticos pela mesma via, intermitentemente à NPT. Esta é infundida por meio de bomba de infusão. Nos horários de administração de antibióticos, infundem-se $1,0 \mathrm{ml}$ de soro fisiológico a $0,9 \%$ pelo cateter PICC e, em seguida, o antibiótico acondicionado em bureta é administrado lentamente, utilizando a via do cateter PICC. Após a administração do antibiótico em recém-nascidos, em sua maioria, pré-termos que permanecem por períodos prolongados de internação e submetidos a diversas punções venosas para coleta de amostras de sangue para exames laboratoriais e infusão de drogas ou soros.

Tabela 28. Variáveis relacionadas ao curativo realizado no cateter PICC. Berçário Anexo à Maternidade do HCFMUSP São Paulo, 2006. (N=24)

\begin{tabular}{|c|c|c|c|c|c|c|c|c|c|c|}
\hline \multirow{3}{*}{ Variáveis } & \multicolumn{10}{|c|}{ Ordem seqüencial dos curativos } \\
\hline & \multicolumn{2}{|c|}{\begin{tabular}{l}
\multicolumn{1}{c}{$1^{\circ}$} \\
Curativo \\
$(\mathrm{N}=24)$
\end{tabular}} & \multicolumn{2}{|c|}{$\begin{array}{c}2{ }^{\circ} \\
\text { Curativo } \\
(\mathrm{N}=15)\end{array}$} & \multicolumn{2}{|c|}{$\begin{array}{c}3^{\circ} \\
\text { Curativo } \\
(\mathrm{N}=3)\end{array}$} & \multicolumn{2}{|c|}{$\begin{array}{c}4^{\circ} \\
\text { Curativo } \\
(\mathrm{N}=1)\end{array}$} & \multicolumn{2}{|c|}{$\begin{array}{c}5^{\circ} \\
\text { Curativo } \\
(\mathrm{N}=1)\end{array}$} \\
\hline & $\mathbf{N}$ & $\%$ & $\mathbf{N}$ & $\%$ & $\mathbf{N}$ & $\%$ & $\mathbf{N}$ & $\%$ & $\mathbf{N}$ & $\%$ \\
\hline Anti-s & & & & & & & & & & \\
\hline Clorex & 18 & 75,0 & 10 & 66,7 & 3 & 100 & 1 & 100 & 1 & 100 \\
\hline PVPI tópico & 6 & 25,0 & 5 & 33,3 & - & & - & - & - & - \\
\hline
\end{tabular}




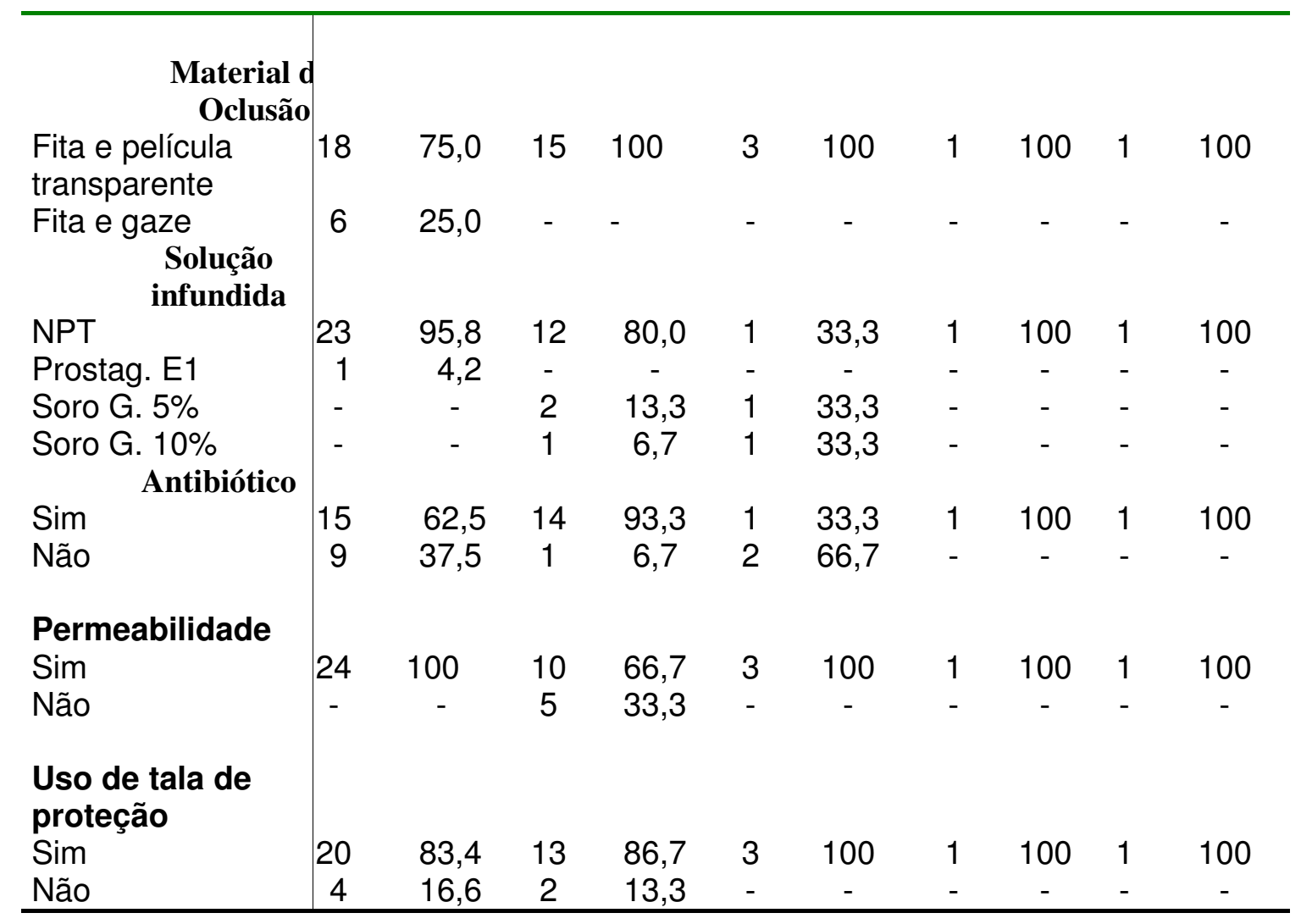

Os dados da Tabela 28 mostram que, no primeiro curativo realizado após 24 horas de inserção do PICC, o uso do anti-séptico clorexidina 0,5\% prevaleceu em todos os curativos realizados; $75,0 \%$ no primeiro curativo, $66,7 \%$ no segundo curativo e $100,0 \%$ no terceiro, quarto e quinto curativos.

O material de oclusão do cateter PICC mais utilizado foi a película transparente e fita estéril (steri-strip ${ }^{\circledR}$ ) verificado nos $18(75,0 \%)$ primeiros curativos e em $100 \%$ nos demais curativos. A solução infundida pelo cateter de maior prevalência foi a NPT, $23(95,8 \%)$ recém-nascidos no primeiro curativo, 12 (80,0\%) no segundo curativo e um (33,3\%) no terceiro curativo. Recebiam infusão de antibióticos, 14 (93,3\%) neonatos e, no terceiro, apenas um $(33,3 \%)$ neonato.

Todos os cateteres PICC inseridos mantinham-se permeáveis no primeiro dia, após sua inserção; já no segundo curativo realizado após uma semana do primeiro curativo, a prevalência de cateteres permeáveis foi de $66,7 \%$. Considerando que o total de neonatos que mantinham o cateter PICC no segundo curativo, era de 15. 
O uso de talas de proteção em membros superiores entre os 24 recém-nascidos submetidos ao primeiro curativo foi verificado em $20(83,4 \%)$ neonatos e do total de 15 neonatos submetidos ao segundo curativo, 13 $(86,7 \%)$ permaneciam com tala. Vale ressaltar que a tala era confeccionada com gaze e fitas adesivas, não havendo, portanto, nenhum tipo de restrição de mobilidade do recém-nascido.

Para manter a permeabilidade do cateter, a instituição adota a prática de infundir um flush de soro fisiológico a 0,9\% com seringa de $10 \mathrm{ml}$ antes e após infundir quaisquer medicamentos. Utilizam-se $2 \mathrm{U}$ de heparina, após a inserção do cateter PICC antes de sua utilização.

Tabela 29. Intercorrências observadas na realização de curativos nos cateteres PICC. Berçário Anexo à Maternidade do HCFMUSP São Paulo, 2006.

\begin{tabular}{|c|c|c|c|c|c|c|c|c|c|c|}
\hline \multirow{3}{*}{ Intercorrências } & \multicolumn{10}{|c|}{ Seqüência dos curativos realizados } \\
\hline & \multicolumn{2}{|c|}{$\begin{array}{c}1^{\circ} \\
\text { Curativo } \\
(\mathrm{N}=24)\end{array}$} & \multicolumn{2}{|c|}{$\begin{array}{c}2^{\circ} \\
\text { Curativo } \\
(\mathrm{N}=15)\end{array}$} & \multicolumn{2}{|c|}{$\begin{array}{c}3^{\circ} \\
\text { Curativo } \\
(\mathrm{N}=3)\end{array}$} & \multicolumn{2}{|c|}{$\begin{array}{c}4^{\circ} \\
\text { Curativo } \\
(\mathrm{N}=1)\end{array}$} & \multicolumn{2}{|c|}{$\begin{array}{c}5^{\circ} \\
\text { Curativo } \\
(\mathrm{N}=1)\end{array}$} \\
\hline & $\mathbf{N}$ & $\%$ & $\mathbf{N}$ & $\%$ & $\mathbf{N}$ & $\%$ & $\mathbf{N}$ & $\%$ & $\mathbf{n}$ & $\%$ \\
\hline Sangramento & & & & & & & & & & \\
\hline Não & 16 & 75,0 & 13 & 86,7 & 3 & 100,0 & 1 & 100 & 1 & 100 \\
\hline Sim & 8 & 25,0 & 2 & 13,3 & - & - & - & - & - & - \\
\hline
\end{tabular}




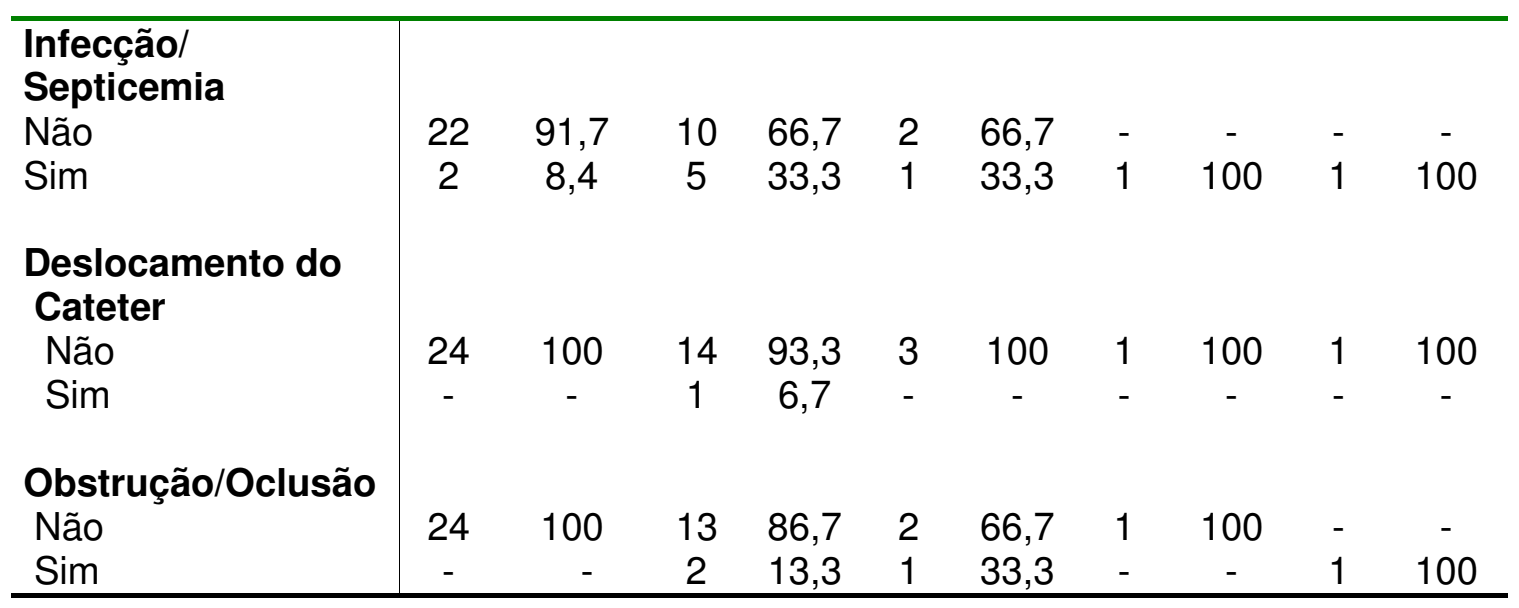

Os dados da Tabela 29 mostram que o sangramento foi a intercorrência mais freqüente nos primeiro e segundo curativos com oito $(25,0 \%)$ e dois $(13,3 \%)$ casos, respectivamente. Por sua vez, a prevalência de infecção/septicemia aumentou com o decorrer da permanência do cateter, chegando a 33,3\%. Vale lembrar que a maioria dos recém-nascidos estudados era prematuro, grupo de risco para desenvolver infecções e esse número baseou-se nos dados coletados dos exames de PCR e hemocultura e não no resultado de cultura de ponta do cateter. A obstrução/oclusão, também, teve uma prevalência crescente ao longo do tempo. No quinto curativo, foi a indicação para remoção do PICC.

Tabela 30. Medidas descritivas do tempo de permanência em dias do cateter PICC nos recém-nascidos. Berçário Anexo à Maternidade do HCFMUSP São Paulo, 2006.

\begin{tabular}{cccccc}
\hline Média & Mediana & Moda & Mínimo & Máximo & $\begin{array}{c}\text { Desvio- } \\
\text { padrão }\end{array}$ \\
\hline 8,9 & 9,0 & 9,0 & 2,0 & 30,0 & 5,5 \\
\hline
\end{tabular}


Verificou-se que a média do tempo em dias de permanência do cateter foi de 8,9 dias, embora tenha sido observada uma grande variação entre 0 período mínimo, dois dias e o máximo de 30 dias.

\subsection{Remoção do PICC}

Tabela 31. Indicação de remoção do cateter PICC. Berçário Anexo à Maternidade do HCFMUSP São Paulo, 2006. ( $N=24)$

\begin{tabular}{lrr}
\hline Motivos de remoção do cateter & $\mathbf{N}$ & $\%$ \\
\hline Infecção & 11 & 27,5 \\
Término da terapia venosa prescrita & 7 & 17,5 \\
Obstrução do cateter & 7 & 17,5 \\
Aumento de circunferência de membro & 3 & 7,5 \\
Extravasamento local & 3 & 7,5 \\
Óbito & 3 & 7,5 \\
Hiperemia local & 2 & 5,0 \\
Retirada acidental do cateter & 2 & 5,0 \\
Realização de dissecção venosa & 1 & 2,5 \\
Formação de cordão fibroso & 1 & 2,5 \\
\hline
\end{tabular}

Os dados da Tabela 31 apontam que houve mais de uma indicação para remoção do cateter a alguns dos recém-nascidos que participaram do estudo. Infecção foi a indicação de suspender o cateter e removê-lo em $11(27,5 \%)$ recém-nascidos. O término da terapia venosa prescrita e a obstrução do cateter foram duas indicações de interrupção do uso de cateter PICC em sete $(17,5 \%)$ recém-nascidos. Dos três recém-nascidos, que tiveram aumento da circunferência de membro, verificou-se diferença de um centímetro comparado à mensuração anterior, sendo dois deles com a ponta do cateter alojada em posição Midline e um em posição Midclavicular. Os três recém-nascidos citados, alojados em posição periférica, devem ter um monitoramento diário da mensuração da circunferência do membro. Esta medida auxilia na avaliação da permeabilidade e no extravasamento da solução infundida. Vale ressaltar que nos três $(7,5 \%)$ neonatos, cujos cateteres foram removidos por óbito, sua causa não tinha relação com o uso do cateter PICC.

Tabela 32. Envio da ponta do cateter PICC para cultura. Berçário Anexo à Maternidade do HCFMUSP. São Paulo, 2006. 


\begin{tabular}{rcc}
\hline Sim & 14 & 58,3 \\
Não & 10 & 41,7 \\
\hline TOTAL & 24 & 100 \\
\hline
\end{tabular}

Tabela 33. Resultado da cultura de ponta do cateter PICC. Berçário Anexo à Maternidade do HCFMUSP. São Paulo, 2006.

\begin{tabular}{lcc}
\hline Resultado da cultura & $\mathbf{N}$ & $\%$ \\
\hline Negativo & 10 & 71,4 \\
Positivo & 4 & 28,6 \\
\hline TOTAL & 14 & 100 \\
\hline
\end{tabular}

Tabela 34. Microrganismos identificados na cultura de ponta de cateter. Berçário Anexo à Maternidade do HCFMUSP. São Paulo, 2006. ( $\mathrm{N}=4)$

\begin{tabular}{lcc}
\multicolumn{3}{c}{ Anexo à Maternidade do HCFMUSP. São Paulo, 2006. (N=4) } \\
\hline Microrganismo identificado & $\mathbf{N}$ & $\%$ \\
\hline Estafilococos Coagulase Negativa & 2 & 50,0 \\
Enterobacter cloacae & 1 & 25,0 \\
Estafilococos epidermidis & 1 & 25,0 \\
\hline TOTAL & 4 & 100 \\
\hline
\end{tabular}

Dos vinte e quatro cateteres inseridos, em 14 (58,3\%) foram enviadas as pontas dos cateteres para cultura em laboratório. O resultado da cultura laboratorial das 14 pontas de cateteres enviadas, a maioria, dez (71,4\%), o resultado foi negativo. Dentre os quatro casos com resultado de cultura positiva, em dois $(50,0 \%)$ identificou-se crescimento de Estafilococos coagulase negativa. 


\section{DISCUSSÃO}

\section{DISCUSSÃo}

A fim de organizar a apresentação da discussão dos resultados, optou-se por seguir os tópicos adotados no capítulo de resultados, a saber:

5.1 Caracterização dos recém-nascidos submetidos ao procedimento de inserção do PICC;

5.2 Inserção do PICC; 


\subsection{Manutenção do PICC e}

\subsection{Remoção do PICC.}

\subsection{Caracterização dos recém-nascidos submetidos ao procedimento de inserção do PICC}

A prematuridade é uma das principais causas de internação nas unidades neonatais, responsável por elevadas taxas de morbidade e mortalidade no período perinatal (Gaíva e Gomes, 2003).

Os dados da Tabela 1 mostram que a média da idade gestacional dos recém-nascidos era de 31,6 semanas. Tawil, Eldermerdash, Hathlol, Laimoun (2006) realizaram um estudo do tipo coorte prospectivo, no qual verificaram a incidência e o local da posição da ponta do cateter PICC de recém-nascidos internados em Unidade de Terapia Intensiva Neonatal (UTIN) de um Hospital da Arábia Saudita no período de 2002 e 2004. Verificaram que a média da idade gestacional dos recém-nascidos foi de 27,7 semanas e de peso 1.040 gramas. A inserção do cateter PICC deu-se com média de idade cronológica de 12,6 dias de vida.

A infusão intravenosa de fluidos pelo cateter PICC é indicada aos recém-nascidos pré-termos e de baixo peso que necessitam receber nutrição parenteral total e drogas vesicantes por veias centrais por períodos prolongados. Vale lembrar que dependendo da idade gestacional e do peso ao nascimento, o período de internação desses recém-nascidos em unidades de terapia intensiva neonatal costuma ser prolongado, expondo-os a infecções hospitalares. Segundo Bayley (2003), o uso do PICC tem se tornado parte integral do manejo dos recém-nascidos de baixo peso, na maioria das unidades de cuidados intensivos.

A população de recém-nascidos do presente estudo foi composta por pré-termos moderados e extremos, $54,0 \%$ nasceram com idade gestacional igual ou inferior a 32 semanas, média de 32,2 semanas e mínima de 26 semanas e 72,3\% com peso igual ou inferior a 1.500 gramas, a média do peso de nascimento foi de 1.289,2 gramas e mínimo de 525 gramas (Tabela 2). 
Sastre, Colomer, Cotallo, Aparício (2000) realizaram estudo prospectivo nos serviços de neonatologia de hospitais integrantes do grupo de Hospitais Castrillo na Espanha, objetivando analisar características técnicas e complicações infecciosas, mecânicas e locais dos cateteres PICC implantados em recém-nascidos. Analisaram 939 cateteres PICC implantados em 787 recém-nascidos. Os resultados mostraram que $57,3 \%$ dos recém-nascidos tinham peso igual ou inferior a 1.500 gramas, prevalência inferior a encontrada em nosso estudo que foi de 72,3\% (Tabela 1). Esta diferença pode ser atribuída às características de morbidade das populações de recém-nascidos estudados nos dois países.

O suporte nutricional parenteral no recém-nascido, segundo Ferferbaum, Delgado e Vaz (2000), pode ser de grande auxilio na profilaxia da desnutrição aguda em prematuros. A Nutrição Parenteral Total (NPT) é administrada por veia central, em razão da alta concentração de glicose e hiperosmolaridade.

Nutrição parenteral por tempo prolongado, solução glicosada em concentração superior a 12,5\%; fármacos aminovasoativos; soluções irritantes e vesicantes devem ser infundidas pelo cateter PICC (NAVAN, 1996). A infusão de NPT em veia periférica aumenta o risco de desenvolver flebites superficiais, extravasamento e infiltração local.

No presente estudo, a implantação do cateter PICC foi indicada pela prescrição de NPT em 35 (94,6\%) recém-nascidos (Tabela 1).

Dispor de acesso vascular central em recém-nascidos internados em unidade de cuidados intensivos neonatais, sobretudo, nos recém-nascidos pré-termos que requerem administração de alimentação parenteral durante o período prolongado de internação que é medida fundamental para a sobrevivência e recuperação desses neonatos (Sastre, Colomer, Cotallo, Aparício, 2000).

É desejável manter acesso venoso prolongado em recém-nascidos de muito baixo peso e naqueles, cuja alimentação oral é contra-indicada (Chathas, Paton, Fischer, 1990). Quando as veias periféricas e a veia umbilical não são alternativas viáveis como acesso venoso, antibióticos, NPT 
e outros fármacos devem ser administrados via acesso venoso central (Foo, Fujii, Harris, LaMorte, Moulton, 2001).

O diagnóstico clínico que prevaleceu nos recém-nascidos submetidos ao PICC foi a Síndrome do Desconforto Respiratório (SDR) ou Doença da Membrana Hialina (DMH), com 56,8\% (Tabela 1). A SDR afeta sobretudo os neonatos prematuros, com peso entre 501 a 1.500 gramas. Prematuridade, sexo masculino, asfixia perinatal são fatores de risco da SDR (Cloherty, Eichenwald, Stark, 2005).

Resultados do exame de hemocultura e Proteína C Reativa (PCR) colhidos previamente ao procedimento de inserção do PICC mostraram que $40,6 \%$ dos recém-nascidos apresentaram hemocultura positiva e desses $73,4 \%$ com PCR superior a $1 \mathrm{mg} / \mathrm{dl}$ (Tabelas 3 e 4). A hemocultura positiva confirma o diagnóstico de septicemia que, por sua vez, é utilizado como indicador de remoção do cateter (Gomella, 2006).

A Proteína C Reativa, segundo Gomella (2006), é um reagente de fase aguda de origem provavelmente hepática. Por ser um exame quantitativo, considera-se como valor normal o resultado de $\leq 1 \mathrm{mg} / \mathrm{dl}$.

Posen e delemos (1998); Nuntnarumit, Pinkaew, Kitwanwanich (2002) enfatizam que o aumento da Proteína C Reativa ocorre, após a instalação da infecção; entretanto, questiona-se sua validade para realizar diagnóstico precoce.

Nos casos em que a infecção é confirmada, o resultado da Proteína C Reativa apresenta correlação com o sucesso do tratamento com antibiótico que é interrompido, quando o resultado da Proteína C Reativa retorna à normalidade.

De modo geral, o resultado da Proteína C Reativa auxilia no processo decisório das condutas a serem tomadas frente ao quadro infeccioso. Após o início da infecção, há aumento da Proteína C Reativa nas quarta a sexta horas, alcançando o pico com 36 a 50 horas. Nuntnarumit, Pinkaew, Kitwanwanich (2002) recomendam associar o resultado da Proteína C Reativa com os resultados do hemograma e cultura para não se remover 0 cateter desnecessariamente. 
Quanto ao resultado de hematócrito, verificou-se valor igual ou superior a $50 \%$ em $40,6 \%$ dos recém-nascidos (Tabela 5). Considera-se valor inferior a $60 \%$ normal para recém-nascidos.

Em razão da perda de $8 \%$ a $10 \%$ do peso do recém-nascido, nas primeiras 48 horas de vida, ocorre uma hemoconcentração e aumento do hematócrito, acarretando alteração na viscosidade sangüínea (Sola, Del Vecchio, Edwards, Suttner, Hutson, Christensen, 2001; Gomella, 2006).

No que se refere ao resultado da contagem de plaquetas, a contagem normal é maior que $200.000 \mathrm{U} / \mathrm{mm}^{3}$. A trombocitopenia é definida como contagem de plaquetas abaixo de $150.000 \mathrm{U} / \mathrm{mm}^{3}$ (Sola, Del Vecchio, Rimasza, 2000; Gomella, 2006). Aos recém-nascidos com plaquetopenia, com quadro evidente de hemorragia e naqueles submetidos a procedimentos cirúrgicos, indica-se transfusão de plaquetas antes de submetê-los à inserção do cateter PICC (Murray, 2002; Kopelman, Santos, Goulart, Almeida, Miyoshi, Guinsburg, 2004).

\subsection{Inserção do PICC}

Como preparo para realizar o procedimento de inserção do cateter PICC foi observada a prescrição de dose intermitente de fármaco sedativo Midazolam administrado por via intravenosa em apenas quatro $(10,8 \%)$ recém-nascidos (Tabela 6). Fármaco analgésico de uso tópico ou sistêmico não foi prescrito e administrado a nenhum recém-nascido, submetido ao procedimento de inserção do PICC. 
Os recém-nascidos internados em unidades de cuidados intensivos são submetidos a freqüentes procedimentos dolorosos, como: coleta de amostra de sangue por venopunção e punção capilar, entre outros. Dor é um evento estressante que conduz à desorganização fisiológica e comportamental com conseqüências, incluindo a dor crônica e alterações neurocomportamentais em resposta à dor (Stevens, McGrath, Gibbins, Beyene, Breau, Camfield, 2003; Simons, Dijk, Lingen, Roofthooft, Duivenvoorden, Jongeneel et al., 2003).

Prestes, Guinsburg, Balda, Marba, Rugolo, Pachi, et al. (2005) avaliaram a freqüência com que são empregados analgésicos no alívio da dor desencadeada por procedimentos invasivos em recém-nascidos internados em unidade de terapia intensiva universitárias e qual é o perfil de uso de medicamentos para alívio da dor. O estudo foi de coorte, prospectivo, entre 1 e 31 de outubro de 2001. Foram avaliados todos os recém-nascidos internados em quatro unidades de terapia intensiva. Os dados coletados foram: características gerais da unidade; dados demográficos dos recémnascidos; morbidade clínica e freqüência do emprego de analgésicos. A análise estatística descritiva e a regressão linear múltipla por meio do SPSS 8.0 foram realizadas para analisar os fatores associados ao uso de analgésicos nesta coorte.

Segundo os autores, no período, foram internados 91 recém-nascidos (1.025 pacientes-dia). Apenas 25\% receberam alguma dose de analgésico por via sistêmica. Não foi administrada nenhuma medicação específica para alívio da dor aguda durante os seguintes eventos dolorosos: intubações traqueais, punções arteriais e venosas, capilares e lombares. Na inserção de dreno de tórax, $100 \%$ dos recém-nascidos receberam analgesia específica e, para passagem de cateteres centrais, incluindo o cateter PICC apenas $8,0 \%$. O medicamento mais usado foi o Citrato de fentanil (93\%).

A causa para o subtratamento da dor é sobretudo pela dificuldade de se avaliar a dor no recém-nascido pré-termo. A natureza subjetiva da experiência dolorosa impede a aplicabilidade clínica (Kopelman, Santos, Goulart, Almeida, Miyoshi, Guinsburg, 2004). 
Nosso estudo referiu a utilização do Midazolam, como fármaco sedativo empregado na pré-inserção do cateter PICC. Vale ressaltar que 20 (54\%) da população estudada eram de recém-nascidos com idade gestacional igual ou abaixo de 32 semanas.

No estudo realizado por Wildt, Kearns, Hop, Murry, Abdel-Rahman, van den Anker (2001), o Midazolam é um benzodiazepínico muito utilizado na Unidade de Terapia Intensiva Neonatal (UTIN) para procedimentos invasivos. O objetivo do estudo foi analisar a farmacocinética do Midazolam após uma dose de $0,1 \mathrm{mg} / \mathrm{Kg}$ em recém-nascidos prematuros. Os recémnascidos escolhidos foram os que tinham idade gestacional entre 26 e 34 semanas, com mais de três dias de vida, submetidos a um procedimento doloroso e que receberiam o Midazolam. $\mathrm{O}$ estudo foi prospectivo, com $\mathrm{N}$ definido, sendo excluídos os recém-nascidos pré-termos usuários de morfina, dobutamina, dopamina e os que apresentavam alterações renais, hepáticas e neurológicas. Participaram do estudo 24 recém-nascidos prétermos.

Segundo os autores citados, após o Midazolam ser administrado eram obtidos $0,2 \mathrm{ml}$ de sangue arterial, com 0,5, 1, 2, 4, 6, 12 e 24 horas. Por intermédio de um centrifugador, foi separado o plasma sangüíneo das amostras colhidas e por meio da espectrometria a concentração do Midazolam no plasma foi analisada. Pelos resultados, observou-se que, quanto menor a idade gestacional do recém-nascido, mais tempo a concentração do Midazolam fica detectável no plasma (24 horas), pela imaturidade hepática. A concentração do Midazolam por mais de 12 horas provoca alterações graves na função hepática e renal de recém-nascidos prematuros, devendo ser utilizado com muita cautela nas UTIN, em especial, quando é administrado mais de uma vez durante 24 horas.

Waisman, Weintraub, Rotschild, Bental (1999) justificando a escassez de estudos que reportam os benefícios do uso do sedativo Midazolam em prematuros, publicaram relato de três casos de recémnascidos prematuros com idade gestacional entre 26 e 32 semanas que apresentaram quadro de acentuada mioclonia por um período de mais de 10 
minutos, após receberem Midazolam, $0,1 \mathrm{mg} / \mathrm{Kg}$ em "bolus". Vale lembrar que a mioclonia também foi observada em um recém-nascido (2,7\%), após administração intravenosa do Midazolam, em "bolus", durante a realização do procedimento de inserção do cateter PICC.

Segundo Guinsburg (1999); Guinsburg, Elias, Balda (2004), os sedativos são agentes farmacológicos que diminuem a atividade, a ansiedade e a agitação do paciente, mas não reduzem a dor.

Quanto ao tipo de cateter utilizado, o poliuretano foi usado em 94,6\% dos recém-nascidos (Tabela 7). Schüller, Maciel, Ichikawa (2005) referem que os cateteres de silicone apresentam termoestabilidade com alta resistência a dobras, enquanto o poliuretano tem maior rigidez e é menos moldável.

Salis, Eclavea, Johnson, Patel, Wong, Tennery (2004) avaliaram vários tipo de cateteres de poliuretano e silicone para identificar sua resistência. A amostra do estudo foi composta por 232 cateteres PICC. Os resultados dos testes mostraram que os cateteres de poliuretano foram mais resistentes do que os de silicone, apresentando menos roturas em sua extensão.

Evans e Lentsch (1999) relataram as diferenças entre o cateter percutâneo de poliuretano, silicone, polietileno e o teflon. A pesquisa foi retrospectiva realizada entre 1993 e 1997, com recém-nascidos de uma Unidade de Terapia Intensiva Neonatal.

O objetivo do estudo foi comparar todos os materiais que são construídos, o cateter percutâneo e verificar qual é o melhor material para a unidade neonatal. Os resultados encontrados pelos autores foram: o polietileno e o teflon apresentaram características parecidas, com maior incidência para trombose de veia cava em comparação com o poliuretano e o silicone. A incidência de tromboflebite foi maior em recém-nascidos que utilizaram cateter de silicone em comparação aos que usaram cateteres de poliuretano. Os cateteres de silicone são menos resistentes do que os de poliuretano, com presença maior de fraturas. As taxas de bacteremias foram maiores dos cateteres de teflon e polietileno. A conclusão dos autores foi 
que em cada material construído, o cateter percutâneo possui vantagens e desvantagens, mas, aos recém-nascidos, o emprego do poliuretano e do silicone são os melhores indicados.

Sabendo que o cateter de poliuretano foi o mais empregado no presente estudo, em comparação com os estudos citados anteriormente, concluiu-se que a utilização do poliuretano, foi uma opção para recémnascidos criticamente doentes.

Ao escolher o cateter PICC, o enfermeiro deve analisar as características do material que influencia no sucesso do procedimento (Renner, 1998).

Liossis, Bardin, Papageorgion (2003) realizaram estudo clínico, coorte, com recém-nascidos menores que 1.000 gramas, comparando 0 cateter PICC com o cateter de linha periférica. Foram estudados 88 recémnascidos, sendo 44 (grupo estudo-PICC) e 44 (grupo controle-linha periférica). A idade gestacional e o peso foram idênticos nos dois grupos, estando a idade gestacional entre 23 e 27 semanas e o peso entre 784 e 793 gramas.

Segundo os autores citados, os resultados encontrados foram: veias mais puncionadas (axilar, basílica, cefálica do membro superior direito) em ambos os grupos; sucesso da inserção na primeira tentativa (ambos os grupos tiveram uma média de 74\%); média de duração do dispositivo (PICC28 dias; linha periférica-13 dias); razão para a remoção do cateter (PICCtérmino da terapia e obstrução; linha periférica-infiltração e vazamento); episódios de infecção durante o uso do dispositivo (PICC-3 episódios; linha periférica-12 episódios). Conclusão: O risco de infecção para um recémnascido com peso inferior a 1.000 gramas é preocupante na unidade neonatal. As múltiplas punções venosas aumentam essa taxa de infecção, além de um ônus, dor e estresse. O cateter PICC é mais vantajoso para essa população, porque tem maior durabilidade, menor taxa de infecção e diminui a manipulação excessiva do neonato criticamente doente.

Estudo conduzido por Franck, Hummel, Connell, Quinn, Montgomery (2001) objetivou a caracterização do recém-nascido onde o 
cateter PICC é inserido: o sucesso na primeira tentativa; solução infundida após a liberação do cateter; média de tentativa de inserção do PICC e uso de fármaco analgésico.

Os recém-nascidos estudados estavam internados em um grande centro hospitalar da Califórnia (EUA), onde enfermeiros qualificados eram responsáveis pela inserção, manutenção e remoção do cateter PICC. Foram estudados 264 recém-nascidos, com idade gestacional média de 34,5 semanas e peso de 2.380 gramas. O sucesso na inserção do PICC na primeira tentativa foi de $94 \%$. A solução mais infundida foi a nutrição parenteral, acompanhada de antibióticos ou não, com $56 \%$. A média de tentativas de inserção foi de 2,2 tentativas, com máximo de 12 e um mínimo de um. A analgesia era indicada apenas aos recém-nascidos que recebiam mais de três punções, sendo o citrato de fentanil o fármaco mais utilizado.

A freqüência de punções venosas realizadas nos trinta e sete recém-nascidos estudados (Tabela 8) variou de uma a nove punções, com média de 3,4 punções. A freqüência de sucesso na primeira punção foi de $21,6 \%$, porcentual inferior ao citado nos estudos de Franck, Hummel, Connell, Quinn, Montgomery (2001); Liossis, Bardin, Papageorgion (2003), apontando para a necessidade de aprimorar a avaliação do recém-nascido e rever a habilidade no procedimento de inserção do cateter.

Phillips (2001) defende que o enfermeiro deve realizar a punção venosa com eficácia e habilidade psicomotora.

Crawford, Soukup, Woods, Deisch (2000) relatam que o sucesso na inserção do PICC requer habilidade na punção venosa, na inserção da ponta do cateter a se dirigir e alojar-se na veia cava. Estudo retrospectivo entre 1996 e 1999, com 700 cateteres PICCs, com os objetivos de caracterizar a população onde foi mais inserido. As principais indicações para a inserção do cateter foram as médias de tentativas até a inserção do cateter; sucesso na inserção; tração do cateter; complicações do cateter. Os resultados indicaram que $52 \%$ dos pacientes que receberam o PICC, foram do sexo feminino; idade entre 21 e 96 anos; principal indicação (nutrição parenteral, antibióticos, drogas vasoativas, terapia com heparina); a média de tentativas 
foi de 2,0 punções. $O$ cateter foi inserido com sucesso na segunda punção com $71 \% ; 28 \%$ dos cateteres foram tracionados; as complicações referidas foram: flebites, vazamento, oclusão, infecções sistêmicas.

Os autores concluíram que o cateter PICC preserva a rede venosa e é uma opção de menor custo, mas é necessário caracterizar as práticas que envolvem sua inserção e manutenção, bem como inserir um programa em toda a instituição que seja um guia para a boa prática de inserção, manutenção e remoção do cateter.

Apesar da população de nosso estudo ser de neonatos, vale lembrar que a boa prática de inserção, manutenção e remoção do cateter serve para qualquer faixa etária.

A SOBETI (2004) enfatiza a importância da avaliação das condições clínicas do paciente e da rede venosa para se indicar o procedimento. Cabe aos serviços de atendimento neonatal implementar a sistematização da assistência de enfermagem (SAE) e adotar protocolo sobre o procedimento de inserção do PICC.

Estudo retrospectivo realizado por LaRue (2000) comparou 431 pacientes submetidos ao procedimento de inserção do cateter PICC de forma convencional com 326 pacientes que utilizaram a ultra-sonografia, como recurso para visualizar a inserção do cateter PICC. Verificou uma redução de $42,0 \%$ do número de punções venosas no grupo visualizado com ultra-som. $O$ autor enfatiza a importância da habilidade técnica na inserção do cateter na redução de punções venosas.

A monitorização do recém-nascido prematuro é de extrema importância nas UTI neonatais, sendo parte integrante da assistência intensiva e envolve o controle de parâmetros clínicos, metabólicos, respiratórios, etc. (Fazio Jr, Carvalho, Nogueira, Carvalho, 1999).

Particularmente, se os recém-nascidos forem submetidos a procedimentos invasivos, monitorar seus sinais vitais, freqüência cardíaca e saturação de oxigênio são medidas recomendadas que auxiliam o profissional avaliar as condições do neonato e a tomar decisões durante a realização do procedimento de inserção do cateter PICC. 
Segundo Guinsburg, Elias, Balda (2004), a freqüência cardíaca após um estímulo nociceptivo apresenta aumento em termos absolutos ou maior variabilidade em relação ao valor de repouso. Isto ocorre durante e imediatamente após o estímulo doloroso agudo. Guinsburg (1999) relata que a mensuração da FC é um dos parâmetros fisiológicos mais monitorados em recém-nascidos doentes, em razão da ativação das respostas resultantes do sistema nervoso simpático, após um procedimento doloroso.

Nos dados da Tabela 10, verifica-se que muitos recém-nascidos mantinham uma freqüência cardíaca maior que 160 batimentos por minuto, antes de serem submetidos à inserção do cateter PICC.

Kopelman, Santos, Goulart, Almeida, Miyoshi, Guinsburg (2004) citam que a insuficiência hemodinâmica do neonato pode aumentar sua freqüência cardíaca e o fato ocorre em razão de um mecanismo de compensação para elevar o débito cardíaco e manter a oxigenação tecidual.

Guinsburg, Elias, Balda (2004) relatam que os estímulos dolorosos em recém-nascidos manifestam-se por meio de mudanças adversas significativas em múltiplos órgãos e sistemas, incluindo o sistema cardiovascular, com aumento da freqüência cardíaca e no sistema respiratório, com elevação do consumo de oxigênio. Os estímulos dolorosos manifestam-se também, repercutindo na diminuição da motilidade gástrica, retenção de hormônio antidiurético e hipercoagulação, entre outras. Tais alterações podem ser observadas em resposta a estímulos dolorosos agudos, como a venopunção, sobretudo em recém-nascidos gravemente doentes.

Guinsburg (1999) relata que a mensuração da freqüência cardíaca é um dos parâmetros fisiológicos mais monitorados no recém-nascido doente, pela ativação das respostas resultantes do sistema nervoso simpático, após um procedimento doloroso. Várias escalas são utilizadas, mas a PIPP (Perfil de Dor no Prematuro) analisa a dor aguda de RN pré-termo e utiliza a freqüência cardíaca como um dos indicadores. Por meio desse dado, a observação de taquicardia foi aferida nas Tabelas 16 e 17. 
Em relação à saturação de oxigênio (Tabela 11), as médias mantiveram-se acima de $90 \%$. Apenas foi verificado um caso de queda na saturação de oxigênio associada no procedimento (Tabela 16).

Antes de realizar quaisquer punções venosas, o enfermeiro precisa conhecer as respostas fisiológicas do sistema vascular quanto ao calor, frio, estresse e estar familiarizado com a espessura e consistência da pele de vários locais (Phillips, 2001).

As veias preferenciais para a inserção do cateter PICC são as localizadas em membros superiores, na ordem que se segue: basílica, posteriores e cefálicas, por apresentarem estrutura e anatomia mais definidas e, como segunda opção, as veias cubitais (Silva e Nogueira, 2004).

As veias puncionadas para a inserção do cateter PICC (Tabela 12) foram as localizadas em membros superiores, sobretudo as do membro superior direito (MSD). Estes dados podem ser justificados em razão da menor extensão a ser percorrida pelo cateter do local puncionado à veia cava superior e menor quantidade de válvulas existentes, o que aumenta a chance de sucesso na passagem do cateter PICC. Nas primeiras punções, a veia basílica foi a mais puncionada, $54,1 \%$, seguida da veia cefálica. Os dados obtidos corroboram as citações de Phillips (2001) de que as veias preferenciais para inserção do cateter periférico central são as basílicas e as cefálicas por apresentarem menor resistência na introdução do cateter.

O curso de qualificação oferecido pela SOBETI (2004) especifica, como acessos preferenciais ao recém-nascido as veias basílica e cefálica. A veia basílica pelo diâmetro maior de sua luz na região cubital, pela lateralização no antebraço e menor angulação e, pelo menor número de válvulas em seu trajeto, com apresentação de quatro a oito válvulas.

Pela sua maior visibilidade na região cubital, a veia cefálica é mais delgada quando comparada à veia basílica e com curso variável e apresenta maior quantidade de válvulas, de seis a dez. Assim, justifica-se a maior prevalência do acesso venoso das veias basílica e cefálica na população estudada (Tabela 12 e 13). Considerando que as enfermeiras do estudo que inseriram os cateteres PICC, foram todas qualificadas pela SOBETI. 
O estudo prospectivo, coorte, que incluiu todos os neonatos submetidos à implantação do cateter PICC, entre fevereiro de 2001 e abril de 2002, foi realizado no Berçário do Hospital das Clínicas da Universidade Federal de Minas Gerais. Envolveu 111 recém-nascidos, 69 do sexo masculino e 42 feminino com 31 semanas de média da idade gestacional e média de 1.511 gramas de peso de nascimento. Pelo estudo, foi verificado que as veias preferenciais puncionadas para inserção do cateter PICC foram localizadas em membro superior $66,7 \%$; seguidas das veias do segmento cefálico 14,4\%; membros inferiores $10,8 \%$ e região cervical $8,1 \%$. As veias preferenciais não foram citadas no estudo (Pereira, Costa, Miranda, Silva, 2006).

Amorim, Pinto, Santos (2006) entrevistaram onze enfermeiros de dois hospitais de São Paulo para verificar o conhecimento sobre a utilização do PICC em crianças. Entre outros dados, identificaram as veias basílica e cefálica como preferenciais para inserção do PICC.

Os motivos de insucesso das punções na inserção do cateter PICC estão relacionados ao recém-nascido de forma direta e indireta. São classificadas como causas diretas as relacionadas à anatomia e fisiologia do neonato e como indiretas, os fatores relacionados à habilidade do enfermeiro que realiza o procedimento.

Os dados das Tabelas 14 e 15 mostram que as principais causas de insucesso foram: fragilidade vascular, transfixação da veia, agitação do recém-nascido, formação de hematoma e válvula vascular fechada.

Em todas as nove punções realizadas, a fragilidade vascular foi a ocorrência mais prevalente, acima de 50\% (Tabela 14 e 15). A fragilidade vascular é comum sobretudo em recém-nascidos prematuros; entretanto é verificada ou agravada em qualquer recém-nascido que tenha sofrido hipoxia prolongada. Acidose, hipoxia e hipercapnia causam vasoconstrição da pequena circulação, prejudicando a circulação normal (Phillips, 2001).

Vale ressaltar que as enfermeiras participantes do estudo apontaram a fragilidade vascular, como motivo de insucesso na inserção do 
PICC pela dificuldade de em inserir a agulha introdutória na veia de escolha em decorrência da vasoconstrição periférica.

No entanto, não foram encontrados estudos que atribuíssem a fragilidade vascular como motivo de insucesso.

$\mathrm{Na}$ tentativa de obter sucesso na inserção do cateter PICC pode ocorrer a transfixação da veia e a formação de hematoma, observados em todas as punções venosas (Tabela 14 e 15). A transfixação da veia e a formação de hematoma foram relatadas como motivos de insucesso associados, apesar de ocorrer a transfixação venosa, a formação de hematoma nem sempre acontece. Segundo Gomella (2006), o hematoma local pode ser manejado efetivamente pela pressão manual delicada sobre 0 local.

Segundo Phillips (2001) a ocorrência de hematoma está relacionada à técnica utilizada para realização do procedimento de punção venosa periférica que envolve: tentativa de punção sem sucesso e uso de torniquete ou garrote apertado em local onde, previamente, já foi puncionado. Os sinais e sintomas relacionados à formação de hematoma são: mudança da coloração da pele ao redor do sítio de inserção do cateter e edema.

A agitação do recém-nascido (Tabelas 14 e 15) foi uma ocorrência verificada em todas as punções venosas alegadas pelas enfermeiras, como motivo do insucesso na inserção do cateter PICC. Chama atenção que a agitação motora da criança foi motivo de insucesso da punção em $75,0 \%$ dos procedimentos realizados. A punção venosa na inserção do cateter PICC é um procedimento doloroso e medidas de analgesia e controle da dor devem ser adotadas uma vez que o sucesso do procedimento depende da agitação do recém-nascido.

O fechamento de válvula vascular foi o terceiro motivo de insucesso na primeira punção verificado em 12 (32,4\%) procedimentos. Algumas veias possuem válvulas com projeções semilunares da camada íntima, formadas por endotélio, colágeno e fibras elásticas que transportam sangue contra a gravidade e ajudam a prevenir o refluxo distal do sangue. Estão localizadas nos pontos de ramificação, produzindo uma saliência no vaso. Ao inserir o 
cateter PICC, as válvulas fecham-se e impedem a passagem do cateter (Phillips, 2001).

Merrell, Peatross, Grossman, Sullivan, Harker (1994) relatam que a principal causa de insucesso na inserção do cateter PICC é a dificuldade de progressão do cateter pelas válvulas vasculares que se fecham e impedem a ponta do cateter progredir e alcançar a veia cava superior.

No estudo realizado com enfermeiros da área de pediatria capacitados no procedimento de inserção do cateter PICC, em dois hospitais da rede pública, ambos localizados na cidade de São Paulo, em que 11 enfermeiros qualificados para a implantação do cateter PICC fizeram parte. Os dados foram coletados por meio de um questionário, utilizando-se um formulário, contendo duas partes: a primeira, com dados de identificação dos enfermeiros e a segunda, com perguntas abertas e fechadas sobre as vantagens, desvantagens e dificuldades identificadas pelos enfermeiros em relação à utilização do PICC. Assim, foi observado que, dentre as vantagens do uso do PICC para a criança, destacam-se a diminuição do número de punções (30\%), a diminuição do estresse da criança $(23,2 \%)$ e a possibilidade de um acesso seguro para antibioticoterapia, nutrição parenteral prolongada $(16,6 \%)$ foram as mais citadas pelos enfermeiros. Cinco enfermeiros $(38,4 \%)$ não apontaram nenhuma desvantagem na utilização do PICC e quatro $(30,7 \%)$ identificaram a falta de cuidados com a manutenção. Dentre as dificuldades reconhecidas pelos profissionais na instalação do PICC, seis $(35,2 \%)$ citaram a dificuldade de progressão do cateter, dois $(11,7 \%)$ dificuldade de visualização da veia e atipicidade de vasos. Quanto às dificuldades na manutenção do PICC, oito enfermeiros $(42,1 \%)$ citaram a manipulação inadequada pelos profissionais e dois $(10,5 \%)$, a obstrução freqüente do cateter, curativo inadequado e déficit no treinamento da equipe. Em relação às dificuldades na retirada do cateter, nenhuma foi citada (100\%). O estudo concluiu que a educação continuada é fundamental no aprimoramento da equipe de enfermagem, como também a implantação de protocolos de cuidados para nortear e proporcionar uma assistência com qualidade (Amorim, Pinto, Santos, 2006). 
Os dados das Tabelas 16 e 17 mostram que a alteração da viscosidade sangüínea foi a mais prevalente intercorrência em todas as punções.

A implantação do cateter PICC deve ser evitada em bebês com hematócrito elevado por causa do risco de obstrução do cateter em função do aumento da viscosidade sangüínea (Silva e Nogueira, 2004).

Vale lembrar que no presente estudo $40,6 \%$ dos recém-nascidos apresentaram resultado de hematócrito (Tabela 5 ) igual ou superior a $50 \%$. Durante a inserção do cateter, a freqüência cardíaca foi monitorada e a taquicardia foi uma das intercorrências apresentadas. Os recém-nascidos, em sua maioria, eram pré-termos de baixo peso. Portanto, a própria manipulação dos profissionais na realização do procedimento pode ter induzido à taquicardia. A prevalência de sucesso no procedimento de inserção do cateter foi de $72,3 \%$ (Tabela 18), sendo maior nas primeira e segunda punções, $21,6 \%$ e 31,0\% (Tabela 9) respectivamente, excetuando a nona punção na qual somente dois recém-nascidos foram submetidos. Entretanto, o sucesso na progressão do cateter não é garantia de que sua ponta tenha se direcionado e posicionado na veia cava.

A confirmação da posição da ponta do cateter pode ser visualizada por injeção de contraste radiopaco por exame de radiografia e ultrasonografia (Kaye, Sane, Towbin, 2000; Moureau, 2003).

Os dados da Tabela 19 mostram que, dos 27 procedimentos com sucesso na inserção pelo exame de radiografia de tórax, visualizou-se que, em $13(48,2 \%)$ recém-nascidos, a ponta do cateter PICC havia ultrapassado a veia cava superior, alojando-se abaixo do átrio direito, indicando que o comprimento do cateter inserido foi além do necessário. Por sua vez, sete pontas de cateteres $(25,9 \%)$ estavam posicionadas na veia cava superior e em três $(11,1 \%)$ a ponta extraviou-se do percurso planejado e foi alojar-se na veia jugular, o que indicou a remoção dos cateteres. Dos 24 cateteres inseridos que restaram, $13(54,2 \%)$ foram tracionados para reposicionar a ponta do cateter em veia cava superior (Tabela 20). 
Ault, Ng, Artal (2001) encontraram em 5.000 tentativas de inserção do cateter PICC, as médias de 96,3\% a 99,5\% de sucesso na inserção do PICC, e em $68 \%$ dos casos, o cateter foi mantido até a conclusão da terapia intravenosa.

Tawil, Eldermerdash, Hathlol, Laimoun (2006) encontraram uma taxa de sucesso na implantação do cateter PICC de $84 \%$ ao avaliarem prospectivamente 41 procedimentos de inserção do cateter PICC em recémnascidos internados na UTI neonatal do National Guard Hospital, situado na cidade de Riyadh na Arábia Saudita.

Geddes e Nichols (2005) citam que a ponta do cateter quando mal posicionada pode levar a sérias complicações. Uma delas é a arritmia cardíaca que ocorre quando a ponta do cateter está abaixo do átrio direito ou abaixo do ventrículo direito.

Segundo Vesely (2003), quando a ponta do cateter está na entrada da veia cava superior, o risco para formação de trombos e flebite aumenta.

Do grupo de recém-nascidos, cujos cateteres foram tracionados, nove $(69,2 \%)$ tiveram suas pontas reposicionadas para o terço inferior da veia cava superior e quatro $(30,8 \%)$ no terço superior e médio da veia cava (Tabela 21).

A SOBETI (2004) recomenda que a ponta do cateter deve estar, preferencialmente, no terço inferior da veia cava superior ou em veia braquiocefálica, para que se possa considerar o cateter como central. Já Kaye, Sane e Towbin (2000) referem que a melhor posição para manter a ponta do cateter é logo acima ou na junção cavo atrial ou na porção da extremidade superior atrial.

Racadio, Doellman, Johnson, Bean, Jacobs (2001) compararam a ponta do cateter PICC que era alojada em região central e periférica. Definiram como central, a ponta do cateter posicionada na veia cava superior, átrio direito ou veia cava inferior alta. Dos 1.266 PICCs analisados, $87 \%$ estavam em região central e $13 \%$ em região periférica (midclavicular ou midline). As complicações encontradas no grupo inserido em região periférica foram de $28,8 \%$. 
No grupo estudado, verificou-se que $83,3 \%$ das pontas dos cateteres posicionaram-se centralmente (Tabela 22). Os 20 cateteres atribuídos como centrais, eram os que já se mantinham na veia cava superior ( $\mathrm{N}=7$ ) (Tabela 19) e os que após a tração posicionaram-se nesta veia $(\mathrm{N}=13)$ (Tabela 20 e 21).

Galloway e Bodenham (2004) realizaram estudo sobre a localização da ponta do cateter PICC. Encontraram freqüência que variou de $25 \%$ a $40 \%$ de falhas no posicionamento da ponta do cateter PICC nas tentativas de punção venosa. Verificaram que pontas posicionadas em veia axilar, subclávia e inominada apresentam $60 \%$ de chance de ocorrência de trombose e em veia cava superior, $21 \%$.

A permanência do PICC está relacionada diretamente ao posicionamento da ponta do cateter. Racadio, Doellman, Johnson, Bean, Jacobs (2001) analisaram 1.096 cateteres centrais e verificaram que sua média de permanência foi de 16 dias e das 169 pontas posicionadas, perifericamente, nove dias.

Nadroo, Magid, Lin, Green, Holzman (2001) enviaram cem questionários a 83 diretores de unidades de cuidado intensivo neonatal com perguntas relacionadas à prática de inserção, manutenção e remoção do cateter PICC. A maioria $(89,0 \%)$ respondeu que utiliza medidas para determinar o comprimento do cateter a ser inserido, $45 \%$ citaram cortar o cateter em seu comprimento, aproximando-o do comprimento ideal. Todos responderam utilizar radiografia para confirmar a posição da ponta do cateter, antes de infundir quaisquer soluções. Com relação à posição da ponta do cateter, $70 \%$ responderam que o átrio direito é o local ideal.

Os estudos mostraram não haver consenso entre os neonatologistas quanto ao melhor local para posicionar a ponta do cateter.

Para Bianchi-Sand (2003) a comunicação efetiva entre médicos e enfermeiros é vital para indicação de um dispositivo intravenoso adequado. As condutas de ambos influenciam diretamente no sucesso de qualquer terapêutica. 
Após a inserção do cateter PICC, sugere-se confirmar a posição da ponta por meio de exame de radiografia de tórax.

A SOBETI (2004) recomenda que o enfermeiro desenvolva habilidades na avaliação radiológica, direcionada a observação do trajeto do cateter até a ponta. Antes da inserção do cateter PICC, é preciso mensurar a extensão da veia, seguindo seu suposto trajeto do sítio da punção até a junção manúbrio esternal com a cabeça da clavícula direita, após descer paralelamente ao esterno até o terceiro espaço intercostal. Este é o procedimento de mensuração indicado para definir o comprimento do cateter a ser inserido pela veia do recém-nascido.

Segundo Pérez, Faunes, Avaca, Torres, Galleguillos, Solis, et al. (2002), a medida de comprimento do cateter PICC a ser inserido depende da veia e do membro escolhido, esta medida é em torno de 10 a $15 \mathrm{~cm}$. Os dados da Tabela 23 mostram o comprimento do cateter introduzido, em centímetros, nos membros superiores e região cervical. $\mathrm{Na}$ instituição estudada, essa medida é realizada pelo enfermeiro responsável pelo procedimento.

Fong, Holtzman, Bettmann, Bettis (2001) defendem que os enfermeiros são responsáveis por assistir todos os pacientes com cateter PICC, incluindo a checagem da posição da ponta do cateter pelo exame de radiografia de tórax. Não existem trabalhos científicos que façam alusão a uma medida de cateter ideal, pois há dependência direta do local de punção.

Outro exame completar é o ecocardiograma que permite visualizar e definir a posição da ponta do cateter após sua inserção. Embora a solicitação para realização desse exame não tenha sido para confirmar a posição da ponta do cateter; no presente estudo, ele foi solicitado para avaliar as repercussões da hipoxemia em recém-nascidos com quadro de angústia respiratória. Os dados das Tabelas 24 e 25 mostram a posição da ponta do PICC nos recém-nascidos que realizaram ecocardiograma, oito $(33,3 \%)$ dos quais sete $(87,5 \%)$ mostraram que a ponta estava posicionada em veia cava superior. 
O ecocardiograma é utilizado como recurso para confirmar o diagnóstico de persistência do canal arterial e para acompanhamento do tratamento instituído. Possibilita, também, diagnosticar cardiopatias congênitas significativas (Gomella, 2006).

Chowdhary, Parashar, Buick, Gornall, Corkery (2001) estudaram as complicações decorrentes do uso de cateter PICC em 125 recém-nascidos com idade gestacional entre 25 e 41 semanas com peso entre 630 e 4.200 gramas, no período de dois anos, por meio de um estudo retrospectivo. Verificaram aumento de complicações pertinentes ao cateter após a quarta semana.

Os autores citados radiografaram o tórax sem uso de contraste, após inserirem o PICC para identificar a ponta do cateter na maioria dos casos e usaram contraste nos casos que não visualizaram a ponta. $O$ ecocardiograma foi realizado para controle da ponta do cateter na vigência de possível migração do cateter. As complicações encontradas foram: 24 casos de infecção por Estafilococos epidermidis, 19 casos de sepse com remoção do cateter, cinco casos de sepse tratados com vancomicina; um caso de óbito por sepse fulminante, 11 casos de obstrução com remoção, nove casos de obstrução tratados com urokinase, quatro casos de obstrução e infecção.

O exame de radiografia de tórax verifica a posição da ponta do cateter, para que seja realizado, é necessário que o serviço disponha de equipamento e recurso humano capacitado, uma vez que, após a inserção do PICC precisa-se conferir se a ponta está alojada em local apropriado.

Os dados da Tabela 26 mostram o tempo decorrido entre a tração do cateter e o segundo exame de radiografia de tórax. $O$ tempo foi bastante variável de 10 minutos a 180 minutos ao o primeiro exame de radiografia e de 30 a 120 minutos ao segundo exame. Os dados apontam para a necessidade de se rever o processo de trabalho, no que se refere ao atendimento realizado por outros serviços complementares. Além de analisar a repercussão que este tempo exerce sobre o sucesso do procedimento de inserção do cateter PICC, já que se adota apenas um "flush" de heparina $2 \mathrm{U}$ 
para evitar a obstrução da ponta do cateter por coágulos no período em que se aguarda a realização do exame de radiografia de tórax.

\subsection{Manutenção do PICC}

Manter o cateter PICC pérvio é um dos maiores desafios para os enfermeiros em razão do calibre estreito e da possibilidade de oclusão.

Dependendo de como é feita a manutenção, o tempo de permanência do cateter PICC, após sua instalação, varia de uma semana a seis meses (Freitas, Raposo, Finoquio, 1999).

A manutenção do cateter é realizada diariamente, durante toda a internação do paciente, através da infusão de soro fisiológico a $0,9 \%$ sob baixa pressão antes e após a infusão de medicamentos e soluções intravenosas.

A solução fisiológica a $0,9 \%$ é usada em seringa de $10 \mathrm{ml}$ para "lavar" o lúmen do cateter que tem como objetivo prevenir obstruções causadas por coágulos sangüíneos, soluções ou medicamentos (Silva e Nogueira, 2004).

A nutrição parenteral total (NPT) foi a solução mais infundida pelo cateter PICC (95,8\%) (Tabela 27).

Não sendo recomendada a administração de NPT e outras soluções vesicantes pelo cateter PICC. Segundo Silva e Nogueira (2004), o uso da mesma via de acesso venoso para infundir NPT e outros medicamentos aumenta a possibilidade de ocorrer interação e eleva 0 risco de contaminação da solução e obstrução por incompatibilidade.

Pelo cateter PICC, verifica-se que foram infundidos antibióticos $(62,5 \%)$ e prostaglandinas E1 (4,2\%) (Tabela 27), mostrando que o cateter PICC não foi uma via exclusiva para infusão da NPT. Embora a NPT seja indicada para ser infundida por via exclusiva, os recém-nascidos ficam expostos a infecções em razão de sua própria condição imunológica e necessitam de tratamento com antibiótico por via endovenosa.

As múltiplas punções venosas a que são submetidos os recémnascidos internados em unidades de cuidados neonatais acabam por 
inutilizar as vias de acesso, levando os profissionais de enfermagem a infundirem antibióticos pela mesma via que administra a NPT. Para evitar que haja interações medicamentosas incompatíveis, opta-se por infundir uma única solução por vez e, em seguida, administrar solução fisiológica 0,9\% antes e após a infusão de antibióticos. Assim, a infusão de NPT é temporariamente interrompida para infundir os antibióticos.

Machado, Pedreira e Chaud (2005) referem que o uso de curativo nos cateteres tem a finalidade de prevenir complicações que estão diretamente relacionadas com o tempo de permanência do cateter.

As principais recomendações sobre a manutenção do cateter PICC referem-se aos curativos. Pérez, Faunes, Avaca, Torres, Galleguillos, Solis, et al. (2002) recomendam que a manutenção do cateter seja realizada por enfermeiros capacitados no manejo do cateter PICC com auxílio de outro profissional. Para se evitar complicações mecânicas e infecciosas, deve-se avaliar diariamente o curativo e quando houver sangramento no local da inserção ou desprendimento do filme transparente, recomenda-se refazer o curativo imediatamente e verificar sua permeabilidade.

O curativo protege o local de inserção e evita a migração da ponta do cateter. A utilização de curativo transparente esterilizado é recomendada para que haja inspeção contínua do local de inserção (Becton Dickinson, 2000).

Após 24 horas de inserção do cateter PICC, o curativo original deve ser substituído após a avaliação. Observar sinais de sangramento, hiperemia, tração do cateter e seu funcionamento, detectando perfurações, obstrução e outras intercorrências que afetam o funcionamento do cateter. Como quaisquer outros curativos, recomenda-se a adoção de técnica asséptica na realização do procedimento (Phillips, 2001).

Os curativos de película transparente semipermeável proporcionam: melhor visualização do sítio de inserção que deve ser inspecionado diariamente; maior tempo de permanência ( 5 a 15 dias); funcionam como barreira contra a contaminação externa; aumentam o conforto do paciente (pelo menor volume, menos trocas, risco menor de alergias de contato, 
permite transpiração normal da pele); menor custo (menos troca, menos tempo dispendido, menos risco de trauma cutâneo); maior e melhor fixação do cateter evitando lesões, flebite, tromboses e exteriorização (SOBETI, 2004).

Geddes e Nichols (2005) recomendam o uso de filme transparente no sítio de inserção com uma pequena gaze nas primeiras 24 horas após a inserção do cateter, para que o sangramento seja absorvido e não adira ao cateter no local da inserção. Deve-se remover o curativo transparente com a gaze após 24 horas e utilizar apenas filme transparente para facilitar a inspeção local. As demais trocas de curativo ocorrem a cada sete dias.

Banton e Banning (2002) sugerem o uso de um filme transparente em formato oval impregnado com clorexidina $\left(\right.$ Biopatch $\left.^{\circledR}\right)$, com ação antimicrobiana por sete dias.

Filme transparente e fita adesiva $\left(\right.$ Steri-Strips $^{\circledR}$ ) são os materiais mais empregados na fixação do cateter PICC. O deslocamento do cateter ainda é uma das complicações mais comuns verificadas. Recomenda-se a troca do curativo apenas quando este estiver com secreção ou se não estiver mais oclusivo (Frey e Schears, 2001).

Garlant, Buck, Maloney, Durkin, Toth-Lloyd, Duffy, et al. (1995) realizaram estudo multicêntrico e prospectivo em que compararam o uso de clorexidina a $0,5 \%$, álcool isopropil a $70 \%$ e povidine tópico a $10 \%$. Verificaram quais produtos eram mais efetivos na diminuição da colonização pelo cateter. Durante os primeiros seis meses, utilizaram povidine tópico a $10 \%$ e álcool a $70 \%$ e verificaram que $9,3 \%$ dos cateteres foram colonizados. Nos seis meses seguintes, utilizaram clorexidina a $0,5 \%$ e verificaram que apenas $0,2 \%$ dos cateteres foram colonizados. Concluíram que a clorexidina a $0,5 \%$ foi mais eficaz do que o povidine tópico a $10 \%$, sobretudo, no que se refere ao aumento da colonização pelo cateter.

Ferreira e Ferrareze (2006) na presença de sangramento no local da inserção, indicam a utilização do curativo com filme transparente com gaze e fita adesiva. A troca deve ocorrer com 48 horas e a solução para realizar o curativo é a clorexidina a $0,5 \%$. 
Os curativos realizados (Tabela 28) mostram que o anti-séptico mais utilizado foi a clorexidina a $0,5 \%$ e os materiais consumidos foram a fita esterilizada e a película transparente. Deve-se salientar que o primeiro curativo ocorreu após 24 horas de inserção do cateter e os demais a intervalos de sete dias, conforme o protocolo da instituição.

No primeiro curativo a nutrição parenteral manteve-se com 95,8\%; no segundo curativo, a freqüência de recém-nascidos com NPT reduziu para $80,0 \%$. A infusão de antibióticos no primeiro curativo manteve-se com $62,5 \%$, já no segundo a freqüência de recém-nascidos com antibióticos foi de $93,3 \%$ (Tabela 28).

Segundo Kamala, Boo, Cheah, Birinder (2002), a principal complicação do cateter PICC na administração de NPT é a infecção do cateter. Os recém-nascidos que permanecem por longo período recebendo NPT, são as maiores vítimas de infecções tardias.

Após um levantamento bibliográfico sobre evidências baseadas na prática do impacto do cateter PICC em crianças, Frey e Schears (2001) evidenciaram que os trabalhos relatam os benefícios do uso da heparina sódica, adicionada à nutrição parenteral para redução de infecção, pois possuem resultados parecidos na população adulta e infantil. Os estudos mostram que nenhuma redução foi significativa.

Ryder (2006) cita que a NPT pode trazer duas complicações ao paciente, infecção e obstrução do cateter. Alguns procedimentos evitam o crescimento de bactérias oportunistas na luz do cateter e sua manutenção é fundamental para a não obstrução do cateter.

A permeabilidade do cateter está diretamente relacionada com sua obstrução. Aparentemente, este é o aspecto mais controverso na utilização do PICC. Na literatura, não existe consenso e nenhuma evidência científica que respalde esta prática.

Para manter a permeabilidade do cateter, a SOBETI (2004) recomenda infundir solução fisiológica a 0,9\% com seringa de $10 \mathrm{ml}$ antes e após a administração de qualquer medicamento ou solução intravenosa contínua. Utilizar o método SASH, consiste em "lavar" o cateter com solução 
salina, administrar o medicamento, em seguida, a solução salina novamente e, por fim, heparina. O cateter deve ser lavado com pressão positiva, prevenindo o retorno de sangue para seu interior.

A obstrução ou oclusão, segundo Fong, Holtzman, Bettmann, Bettis (2001), é caracterizada pela interrupção do fluxo sangüíneo para o interior do vaso, causando perda da permeabilidade do cateter. Esta pode ser motivada pelo deslocamento do cateter, em razão de uma fixação ineficaz e uso recorrente de medicações incompatíveis.

Como medida de segurança, recomenda-se nunca utilizar seringas com capacidade menor que $10 \mathrm{ml}$ ao infundir solução fisiológica a $0,9 \%$ pelo cateter PICC e, assim, pressionar exageradamente e induzir rompimento e extravasamento (Phillips, 2001).

Os dados da Tabela 28 mostram que, 24 horas após a inserção do cateter PICC, todos os cateteres mantinham-se permeáveis. No segundo curativo, ou seja, após a segunda semana, a prevalência de permeabilidade do cateter reduziu para $66,7 \%$.

Após a inserção do cateter PICC, o mesmo deve ser fixado com curativo transparente, devendo todo 0 cateter, incluindo, o canhão de conexão permanecer ocluído. A prática permite que o cateter não dobre e evita que ocorra uma tração acidental. Recomenda-se não utilizar nenhum tipo de tala para proteção (Silva e Nogueira, 2004).

Os dados da Tabela 28 mostram que as enfermeiras adotam a prática de manter tala de proteção nos recém-nascidos com cateter PICC. $\mathrm{Na}$ instituição, campo de estudo, o uso de tala é uma prática adotada a fim de prevenir a mobilização do cateter pela adução e abdução dos movimentos do recém-nascido.

Forauer e Alonzo (2000) relatam que a ponta do cateter movimentase, conforme o paciente aduz e abduz o membro superior, onde o PICC está instalado. Os autores inseriram o cateter em veias basílica e braquial guiados pela imagem de ultra-sonografia. $O$ membro onde estava inserido 0 cateter, era colocado em posição de $90^{\circ}$. Os resultados mostraram que $58 \%$ dos PICCs moveram-se $20 \mathrm{~mm}$ ou mais de sua posição original no 
movimento de adução e abdução do membro. Os autores consideraram a importância do exame de radiografia de tórax para identificar a posição da ponta do cateter.

Nadroo, Glass, Lin, Green, Holzman (2002) realizaram estudo sobre a migração de cateteres PICCs e concluíram que os movimentos do braço afetam a posição da ponta do cateter. Analisaram 280 radiografias de 60 recém-nascidos com PICCs inseridos em veia de membros superiores, observaram que a abdução e adução do ombro, flexões e extensões do cotovelo alteram a posição da ponta do cateter.

Connolly, Amaral, Walsh, Temple, Chait, Stephens (2006) referem que a movimentação do braço do recém-nascido interfere na posição da ponta do cateter na veia cava superior, por isso, durante a realização do exame de radiografia de tórax, é necessário manter o membro sempre na mesma posição.

A manutenção diária do cateter PICC diminui progressivamente as intercorrências durante sua permanência. Os dados da Tabela 29 mostram as intercorrências identificadas durante a permanência do cateter PICC.

Verificou-se que a infecção/septicemia e sangramento foram as que mais prevaleceram, com exceção da obstrução, porcentualmente alta, porém observada em uma amostra de um recém-nascido. Gaiva e Gomes (2003) citam que o sistema imunológico local e sistêmico do recém-nascido é imaturo, o que contribui para a suscetibilidade da infecção no período neonatal.

Estudo realizado em Singapura por Chlebicki e Teo (2003) teve como objetivo realizar uma revisão retrospectiva de prontuários médicos de utilização do cateter PICC em pacientes internados nesse hospital no período de julho a outubro de 2002. Setenta e oito pacientes participaram do estudo e 94 PICCs foram inseridos no período. A média de idade dos pacientes era de 58,3 anos e $76,9 \%$ do sexo masculino. O resultado encontrado indicou que $68,1 \%$ dos cateteres PICCs foram instalados para a terapia prolongada de antibióticos, 28,7\% para administração de nutrição parenteral, $3,2 \%$ por outras razões. 
Segundo os autores citados, as veias de escolha foram: basílica $(53,2 \%)$, braquial $(19 \%)$, cefálica $(16,5 \%)$. A média de permanência dos cateteres foi de 17,2 dias, sendo $51,1 \%$ removidos pelo final da terapia. As complicações mais comuns foram: flebite, infecção, oclusão e saída acidental do cateter. Os microrganismos encontrados na ponta do cateter após sua remoção foram: Estafilococos coagulase negativa (12,9\%); Estafilococos aureus (9,7\%), Klebsiella spp (3,2 \%), entre outros. A conclusão do estudo foi que o PICC deve ser utilizado para tratamento de infecções, com a infusão de antibióticos por mais de duas semanas. $\mathrm{Na}$ vigência da administração parenteral, com uso de antibióticos deve-se fazer "flush" diário com solução salina três vezes ao dia para diminuir a oclusão do cateter e a formação de trombos; a ponta do cateter deve ser mandada para cultura, após sua remoção apenas nos casos de suspeita de infecção relacionada ao cateter.

Shah, Kalyn, Satodia, Dunn, Parvez, Daneman, et al. (2007) estudaram a utilização da heparina na prevenção da oclusão do cateter PICC em recém-nascidos. O estudo foi multicêntrico, randomizado, com dois grupos: grupo estudo (infusão de heparina a $0,5 \mathrm{U} / \mathrm{Kg}$ por hora) e grupo controle (placebo). Os 201 recém-nascidos participantes do estudo tinham características iguais em ambos os grupos.

De acordo com os autores citados, o resultado foi que a permanência do cateter foi maior no grupo estudo do que no grupo controle; A incidência para remoção do cateter por término da terapia foi $63 \%$ no grupo estudo e $42 \%$ no grupo controle; A oclusão foi observada em $6 \%$ no grupo estudo e $31 \%$ no grupo controle; A taxa de trombose foi $20 \%$ no grupo estudo e $21 \%$ no grupo controle; cateter relacionado com sepse foi $10 \%$ no grupo estudo e $6 \%$ no grupo controle. Os autores concluíram que a infusão de heparina aumenta a durabilidade do cateter PICC em neonatos criticamente doentes.

Pereira, Costa, Miranda, Silva (2006) argumentam que os estudos sobre a utilização dos PICCs em pediatria mostram reduzidas complicações, entretanto a avaliação de investigações prévias a respeito de complicações 
relacionadas aos PICCs é complexa pelas diferenças nas populações de pacientes, que incluem idade, diagnóstico, técnicas de inserção, tipo de cateteres e definição da posição da ponta do cateter.

O estudo realizado pelos autores citados mostrou que a incidência de complicações não se associou à idade gestacional nem ao peso do recém-nascido. Dos 111 procedimentos de inserção do cateter PICC analisados, os autores identificaram complicações em 59 (53,2\%), dentre elas: $35 \%$ apresentaram infiltração, $20 \%$ removidos acidentalmente, $12 \%$ obstruíram e $12 \%$ por quebra do cateter. Apenas dois casos de infecção local $(1,8 \%)$ e dois pacientes com diagnóstico de sepse relacionada ao cateter $(1,8 \%)$ foram identificados. As infiltrações ocorreram com cateteres em posição periférica.

As complicações mais comuns com o cateter PICC incluem o deslocamento do cateter, cuja prevalência varia de $5 \%$ a $31 \%$ e infecção, com $2 \%$ a $20 \%$ de ocorrência. Infecção é o motivo mais comum de indicação da remoção do cateter (Yamamoto, Solomon, Soulen, Tang, Parkinson, Lin, et al., 2002).

Pettit (2002) cita que o uso do cateter PICC apresenta menos complicações comparadas ao uso do cateter venoso central, particularmente, quanto à infecção. As principais complicações do cateter PICC, segundo dados da literatura são: deslocamento do cateter $(2 \%$ a $11,6 \%)$; oclusão (2,2\% a $33,6 \%)$; infecção ( $0 \%$ a $25 \%)$; quebra $(1,7 \%$ a $10 \%$ ); mau posicionamento ( $1 \%$ a $5,3 \%$ ); flebites ( $0 \%$ a $6,9 \%$ ), etc.

$\mathrm{O}$ cateter pode permanecer por várias semanas e o aumento da taxa de infecção costuma ocorrer após duas a três semanas, depois de sua instalação (Gomella, 2006).

A maioria das infecções relacionadas a cateter é de bactérias da microbiota cutânea, decorrente da contaminação das conexões do cateter, contaminação da infusão e de fonte hematogênica (Phillips, 2001).

A oclusão do cateter ocorre sobretudo por infusão de substâncias incompatíveis, "flushes" inadequados entre uma medicação e outra, falha na 
lavagem com pressão positiva do cateter possibilitando o refluxo sangüíneo. Em relação à infecção pelo cateter, a principal recomendação é a adoção de medidas preventivas simples, como a higienização adequada das mãos antes de manipular as extensões e desinfecção de seus injetores (Pettit, 2002).

Chama atenção que a oclusão foi verificada em dois casos no segundo curativo $(13,3 \%)$, lembrando que neste serviço não se adota a heparina para evitar a oclusão do cateter. É utilizada após a inserção do cateter até o exame de radiografia de tórax. Revisão sistemática conduzida por Shah e Shah (2005) avaliou a efetividade da heparina para prevenir complicações com o cateter PICC em prematuros e recém-nascidos em estado crítico durante a permanência do cateter.

Pereira, Costa, Miranda, Silva (2006) verificaram que o tempo de permanência dos PICCs foi de 13 dias e a maioria dos cateteres foi removida eletivamente. Janes, Kalyn, Pinelli, Paes (2000) compararam o tempo de permanência do cateter PICC com o cateter periférico em crianças com baixo peso. Verificaram que o tempo de permanência dos cateteres centrais era maior que o dos periféricos, com período que variou de 11 a 32 dias.

A média do tempo de permanência dos cateteres neste estudo foi de 8,9 dias (Tabela 30), bem abaixo do encontrado no estudo de Tawil, Eldemerdash, Hathlol, Laimoun (2006) que foi de 20,6 dias para cateteres centrais e seis dias para midline.

\subsection{Remoção do PICC}

Recomenda-se que a remoção do cateter PICC seja lenta e cuidadosa, posicionando o braço do paciente abaixo do nível do coração. Após a remoção, manter curativo oclusivo, certificando-se de que toda a 
extensão do cateter tenha sido removida pela mensuração do comprimento do cateter (SOBETI, 2004).

No presente estudo, não houve caso de intercorrência na remoção do cateter PICC e todos os cateteres removidos apresentaram-se íntegros ao mensurá-los e inspecioná-los.

A indicação eletiva da remoção do cateter PICC por conclusão da terapia intravenosa ocorreu em apenas sete $(17,5 \%)$ recém-nascidos e a indicação para remoção do cateter PICC que mais prevaleceu foi a infecção, 11 (27,5\%) (Tabela 31). Tawil, Eldemerdash, Hathlol, Laimoun (2006) encontraram uma taxa de $76,6 \%$ de indicação eletiva de remoção do PICC e de 10,6\% para infecção, como indicação de remoção do cateter.

Pereira, Costa, Miranda, Silva (2006) identificaram que 46,8\% das remoções do cateter PICC foi eletiva por conclusão da terapia intravenosa; $20 \%$ por saída acidental; $12 \%$ por obstrução e $12 \%$ por quebra. Alertam para a necessidade de manter vigilância, para que não haja aumento das complicações.

Os principais motivos de remoção do cateter em estudo realizado por Chlebicki e Teo (2003) foram: quebras (8,9\%); oclusão (12,6\%); flebites $(2,2 \%)$ e término da terapia $(46,7 \%)$.

Segundo Ferreira e Ferrareze (2006), a remoção do cateter por causa de infecção da corrente sangüínea relacionada ao cateter é comum nas unidades de terapia intensiva. Os autores referem que $90 \%$ das infecções primárias da corrente sangüínea são relacionadas a materiais intravasculares.

Dinc e Erdil (2000); Eggimann, Hugonnet, Sax, Harbarth, Chevrolet, Pittet (2005) relatam que o risco de infecção pelo cateter é reduzido, após a

padronização de técnicas assépticas na inserção e manutenção. É necessário que a equipe profissional seja capacitada para realizar o procedimento de inserção e manutenção do dispositivo e as medidas de assepsia na inserção e nos curativos do cateter sejam rigorosamente seguidas, incluindo, lavagem de mãos antes e após a manipulação do 
sistema. Com tais medidas, as taxas de infecção relacionadas ao cateter são controladas e, conseqüentemente, reduzem a taxa de remoção por infecção.

Recomenda-se solicitar pesquisa de crescimento de cultura da ponta do cateter PICC; para isso, deve-se evitar a contaminação no momento de sua retirada. Esta medida é indicada quando há sinais locais e/ou sistêmicos de infecção, a fim de auxiliar na identificação do microrganismo responsável pelo quadro infeccioso. Além da cultura da ponta do cateter, deverá ser solicitada hemocultura (Silva e Nogueira, 2004).

Os dados da Tabela 32 mostram que $14(58,3 \%)$ pontas de cateteres foram enviadas para análise laboratorial, dos quais em dez $(71,4 \%)$ os resultados foram negativos (Tabela 33 ). Das quatro pontas de cateteres PICC com resultado de cultura positiva, em dois casos foi detectado crescimento de Estafilococos coagulase negativa (Tabela 34).

Segundo Miura (2002), a infecção pela Estafilococos Coagulase Negativa (ECN) vem crescendo nas unidades de terapia intensiva neonatal por meio da fisiopatogenia da bactéria. Esta bactéria adere ao polímero do cateter e forma um biofilme com produção de muco exopolissacarídeo que protege a bactéria contra a ação dos antibióticos.

D' Angio, McGowan, Baumgart, St Geme, Harris (1989) descrevem uma taxa de colonização por ECN entre $50 \%$ a $80 \%$ dos casos até quatro dias, após a admissão dos recém-nascidos em unidade de tratamento intensivo neonatal. Observaram que havia um aumento da resistência a múltiplos antibióticos de $32 \%$ para $82 \%$ no final de uma semana na UTI.

Cunha, Lopes, Rugolo, Chalita (2002) estudaram 54 recémnascidos com infecção por Estafilococos coagulase-negativo. A maioria $79,6 \%$ era prematura, com $33,3 \%$ deles apresentando prematuridade

extrema (<31 semanas) e $50 \%$ com peso de nascimento inferior a 1.500 gramas. Vários fatores contribuem para que os prematuros sejam mais suscetíveis à infecção. A imaturidade do sistema imunológico do recémnascido é a principal. Dentre os fatores de risco para infecção, o uso do cateter foi significativamente mais freqüente. Os cateteres vasculares são 
colonizados com facilidade por microrganismos da pele presentes no local da inserção. A infusão de NPT pelo cateter PICC, especialmente, os lipídeos, atua como meio de cultura que favorece a proliferação bacteriana.

Pereira, Costa, Miranda, Silva (2006) estudaram 61 procedimentos de instalação do PICC em recém-nascidos, verificaram o resultado da cultura de ponta do cateter e encontraram $47,5 \%$ com culturas positivas. A análise estatística realizada mostrou que não houve associação entre a positividade da cultura da ponta do cateter com a prematuridade e o baixo peso dos recém-nascidos estudados. Os autores reafirmam que os PICCs continuam sendo uma ótima opção para esses pacientes, permitindo prolongar o tempo de permanência do acesso venoso sem aumentar a incidência de sepse. Exemplificam ainda um caso em que o cateter permaneceu por 45 dias, sem apresentar cultura positiva e/ou evidência de infecção. A retirada do cateter foi em razão do término do tratamento.

Safdar e Maki (2005) avaliaram 251 PICCs implantados em recémnascido pré-termo e verificaram que a média de permanência do cateter foi de 11,3 dias. A complicação mais encontrada foi a infecção da corrente sangüínea pelo cateter, e $52(20,7 \%)$ foram colonizados e removidos. A cultura da ponta do cateter evidenciou a presença da bactéria Estafilococos Coagulase Negativa.

Brooker e Keenan (2007) conduziram estudo retrospectivo com 101 recém-nascidos pré-termos, com idade gestacional menor que 29 semanas, submetidos ao procedimento de inserção do cateter PICC, objetivando verificar a prevalência de cateteres PICCs removidos por infecção. Dos 101 PICCs, dez casos foram relacionados à infecção e os cateteres foram removidos, destes, apenas em um caso houve confirmação de infecção. Os autores salientam que o surgimento de sepse em um recém-nascido com cateter PICC já promove a intenção da retirada do cateter pelos neonatologistas, sobretudo dos prematuros, por temerem o óbito da criança. 



\section{CONCLUSÃO E CONSIDERACÕES}

\section{FINAIS}

\section{CONCLUSÃO E CONSIDERAÇÕES FINAIS}

Caracterização dos recém-nascidos submetidos à inserção do cateter PICC:

- $22(59,4 \%) \mathrm{RN}$ do sexo masculino;

- $23(62,2 \%) \mathrm{RN}$ com idade gestacional ao nascimento $\leq 32$ semanas;

- Média do peso de nascimento, 1.360 gramas. A maioria, 24 $(64,9 \%) \mathrm{RN}$ com peso ao nascimento $\leq 1.500$ gramas;

- Média da idade gestacional corrigida, 32,2 semanas. A maioria, 20 (54,0\%) RN com idade gestacional corrigida $\leq 32$ semanas; 
- Média do peso na data da inserção do cateter PICC, 1.289,2 gramas. A maioria, 27 (72,3\%) RN com peso $\leq 1.500$ gramas;

- Média da idade cronológica na data do procedimento, 4,3 dias de vida. A maioria, 18 (48,7\%) RN com idade cronológica entre um e três dias de vida;

- A maioria, 21 (56,8\%) com diagnóstico clínico de síndrome do desconforto respiratório;

- A maioria, 35 (94,6\%) RN, com indicação de inserção do cateter PICC para infusão de Nutrição Parenteral Total;

- Com resultado de hemocultura positiva prévia ao procedimento de inserção do PICC, 15 (40,6\%) RN, dentro estes, 11(73,4\%) RN com resultado do exame de proteína C reativa $>1 \mathrm{mg} / \mathrm{dl}$;

- Com resultado de hematócrito > 50\%, $22(59,4 \%) \mathrm{RN}$.

Caracterização da prática de inserção do PICC

- Fármaco analgésico pré-procedimento de inserção do cateter não foi verificado em nenhum recém-nascido. O sedativo Midazolan foi administrado antes da inserção do cateter em 4 $(11,8 \%) \mathrm{RN}$;

- Na maioria, 35 (94,6\%) RN, foi inserido cateter de poliuretano;

- A média da freqüência de punções venosas foi 3,4; havendo uma ampla variação dos valores mínimo e máximo, um e nove punções, respectivamente;

- A freqüência de sucesso na introdução do PICC na primeira punção foi de 21,6\% (8 RN);

- Do total de 127 punções realizadas entre os 37 recém-nascidos que participaram do estudo, o membro superior direito foi o que recebeu maior número de punções, 72 (56,6\%), sendo as veias basílica e cefálica as mais puncionadas, respectivamente, 38 $(29,9 \%)$ punções e 29 (22,8\%) punções;

- Os motivos de insucesso na inserção do PICC na primeira punção venosa foram: fragilidade venosa, 16(43,2\%) RN; 
transfixação da veia, 11 (29,7\%) RN e fechamento de válvula, $12(32,4 \%) \mathrm{RN}$;

- A intercorrência mais freqüente foi a alteração da viscosidade sangüínea, verificada em quatro $(10,8 \%) \mathrm{RN}$;

- Houve sucesso na punção venosa e progressão do cateter em $72,3 \%$ (27 RN) dos procedimentos;

- Dos 37 recém-nascidos submetidos ao procedimento, 27 $(72,3 \%)$ RN tiveram os cateteres introduzidos com sucesso, dos quais, $13(48,2 \%)$ com a ponta localizada em átrio direito; sete $(25,9 \%)$ em veia cava superior; quatro $(14,8 \%)$ em veia axilar ou inonimada e três $(11,1 \%)$ em veia jugular;

- Dos 27 cateteres introduzidos, três $(11,1 \%)$ foram removidos por desvio da ponta para outra ramificação venosa;

- Dos 24 cateteres introduzidos, $13(54,2 \%)$ foram tracionados para reposicionar a ponta;

- Dos 24 cateteres introduzidos, 20 (83,3\%) foram fixados em posição central, três (12,5\%) em posição midline e um (4,2\%) em posição midclavicular;

- A média do comprimento em centímetros do cateter introduzido no membro superior direito foi $11,4 \mathrm{~cm}$; em membro superior esquerdo, $13,5 \mathrm{~cm}$ e em região cervical, $7,1 \mathrm{~cm}$;

- Dos 24 recém-nascidos com PICC, oito (33,3\%) fizeram ecocardiograma e sete $(87,5 \%)$ tinham a ponta do PICC posicionada em veia cava superior;

- A média do intervalo de tempo entre a inserção do cateter e o primeiro exame de radiografia de tórax foi 98,1 minutos e entre a tração do cateter a segunda radiografia, 53 minutos, indicando que o tempo consumido pela enfermeira na realização desse procedimento até a realização da radiografia de tórax superou $1 \mathrm{~h} 30$;

- A prevalência de sucesso na implantação do cateter foi de $64,9 \%$. e em posição central, $54,1 \%$. 
Caracterização da prática de manutenção do PICC

- A média do tempo de permanência do PICC foi 8,9 dias, variando de doía a trinta dias;

- $23(95,8 \%)$ RN receberam Nutrição Parenteral Total pelo cateter PICC e 15 (62,5\%), além dessa solução, receberam antibióticos;

- Submeteram-se ao primeiro curativo, após 24 horas da inserção do PICC, todos os $24(100 \%)$ recém-nascidos. No segundo curativo, realizado na primeira semana, após a inserção do PICC, 15 (62,5\%) RN permaneciam com o cateter PICC. No terceiro curativo realizado na terceira semana, após a inserção do cateter, três (12,5\%) RN permaneciam com o PICC. Apenas um $(4,1 \%)$ recém-nascido estava com cateter nas quarta e quinta semanas;

- Os anti-sépticos utilizados nos curativos foram clorexedina 0,5\%, e PVPI tópico. Fita adesiva e filme transparente foram os materiais mais empregados para fixar e ocluir o local de inserção do PICC;

- Tala de proteção foi observada em uso no primeiro curativo em 20 (83,4\%) RN;

- Todos os 24 cateteres estavam permeáveis no primeiro curativo. No segundo curativo, foram identificados 10 (66,7\%) cateteres pérvios;

- A intercorrência mais freqüente observada no primeiro curativo foi sangramento, $16(75,0 \%) \mathrm{RN}$. O único recém-nascido que foi submetido ao quinto curativo apresentava suspeita de infecção pelo cateter e obstrução do mesmo;

Caracterização da prática de remoção do PICC

- Indicação eletiva de remoção de cateter em virtude de término da terapia intravenosa ocorreu em apenas sete $(17,5 \%) \mathrm{RN}$. A 
indicação de remoção do cateter mais freqüente relacionou-se à: suspeita de infecção, 11 (27,5\%) RN; obstrução do cateter, sete $(17,5 \%)$ entre outros motivos associados;

- Cultura da ponta de cateter foi solicitada para $14(58,3 \%) \mathrm{RN}$ dos quais, $10(71,4 \%)$ o resultado foi negativo.

- Das quatro culturas com resultado positivo, em duas $(50,0 \%)$ identificou-se Estafilococos coagulase negativo.

Ao concluir o presente estudo, são destacadas algumas considerações relacionadas à limitação do estudo e suas implicações na assistência, ensino e pesquisa.

Apesar do reduzido tamanho da amostra estudada, definido em função da cota mensalmente disponibilizada de cateteres PICC para o Berçário, campo do estudo, os resultados apontaram para uma taxa de sucesso no aproveitamento do procedimento de $64,9 \%$; sendo a etapa de inserção do cateter onde houve maior índice de fracasso, 27,0\%.

Estes dados remetem à necessidade de analisar a relação entre cota mensal de cateteres PICC da unidade em relação ao número de recémnascidos com indicação de PICC, levando em consideração a taxa de perdas de cateteres por insucesso no procedimento. Merece, também, ser analisado o procedimento de inserção, particularmente, os fatores que influenciam a freqüência de punções venosas necessárias para introduzir o cateter.

Outro dado a destacar foi o uso predominante de cateteres de poliuretano. A literatura mostra poucos estudos relacionados ao uso com este tipo de material e os resultados de sucesso na instalação do cateter PICC de silicone mostram taxas de sucesso superiores aos encontrados no presente estudo. Vale ressaltar que os motivos de insucesso foram fragilidade venosa e transfixação de veia. Assim, uma revisão no tipo de composição do cateter PICC a ser adquirido pelo serviço é necessária.

O estudo apontou também que nenhum recém-nascido recebeu qualquer tipo de método analgésico, antes de ser submetido ao 
procedimento; entretanto, o uso de fármaco sedativo foi verificado em 11,8\% dos recém-nascidos. Ademais, a agitação do recém-nascido foi um dos motivos de insucesso na inserção do cateter PICC.

Outro dado que chamou a atenção refere-se ao mau posicionamento da ponta do cateter predominantemente ultrapassando a veia cava superior, local ideal para seu posicionamento. Vale rever a técnica de mensuração da extensão do cateter antes da introdução do PICC, uma vez que houve uma grande variação na extensão em centímetros nos dados obtidos neste estudo.

A prática de infundir nutrição parenteral total e antibióticos, de maneira intercalada, pelo PICC pode favorecer a oclusão do cateter e necessita ser revista.

O uso da tala de proteção nos recém-nascidos é uma prática específica do serviço, na literatura, não há respaldo desta prática que precisa de estudos que avaliem sua eficácia.

O tempo médio de permanência do cateter de 8,9 dias foi inferior aos dados da literatura, apontando para a necessidade de rever as práticas adotadas para a manutenção do cateter no que diz respeito à prevenção de infecções e oclusão, as maiores indicações de remoção do cateter.

Vale lembrar que a responsabilidade pelos cuidados com o cateter na unidade estudada é das enfermeiras com qualificação; entretanto, o cateter é manipulado por técnicos e auxiliares de enfermagem responsáveis pelo preparo e administração das soluções infundidas.

Assim, é necessário que todos os profissionais da equipe de enfermagem que atuam na unidade de terapia intensiva neonatal recebam qualificação no procedimento de instalação do cateter PICC, particularmente, as enfermeiras não qualificadas no procedimento tenham apoio e incentivo institucional para sua capacitação. 



\section{REFERÊNCIAS}

\section{REFERÊNCIAS}

Ainsworth SB, Furness J, Fenton AC. Randomized comparative trial between percutaneous longlines and peripherally cannulae un the delivery of neonatal parenteral nutrition. Acta Paediatr. 2001;90(9):1016-20.

Abdullah BJ, Mohammad N, Sangkar JV, Abd Aziz YF, Gan GG, Goh $\mathrm{KY}$, et al. Incidence of upper limb venous thrombosis associated with peripherally inserted central catheters (PICC). $\mathrm{Br} J$ Radiol. 2005;78(931):596-600.

Allen AW, Megargell JL, Brown DB, Lynch FC, Singh H, Singh Y, et al. Venous thrombosis associated with the placement of peripherally inserted central catheters. J Vasc Interv Radiol. 2000;11(10):1309-14.

Amorim FA, Pinto MCM, Santos SR. Vantagens, desvantagens e dificuldades percebidas pelos enfermeiros na utilização do PICC em crianças. Nursing (São Paulo). 2006;9(95):771-5.

Ault MJ, Ng PK, Artal R. The changing use of peripherally inserted central catheters: a review of 5000 insertions at a single hospital. J Clin Outcomes Manage. 2001;8(9):17-23.

Bagtharia R, Kempley ST, Hla TM. Acute neonatal collapse resulting from pericardial effusion. Eur J Pediatr. 2001;160(12):726-7. 
Ballantyne M, McNair C, Ung E, Gibbins S, Stevens B. A randomized controlled trial evaluating the efficacy of tetracaina gel for pain relief from peripherally inserted central catheters in infants. Adv Neonatal Care. 2003;3(6):297-307.

Banton J, Banning V. Impact in catheter-related bloodstream infections with the use of the Biopatch $\AA$ dressing. J. Vasc Access Devices. 2002;7(3):27-32.

Barber JM, Booth DM, King JA, Chakraverty S. A nurse led peripherally inserted central catheter line insertion service is effective with radiological support. Clin Radiol. 2002;57(5):352-4.

Bayley G. Technique for insertion of percutaneous central venous catheters in the newborn period. Arch Dis Child Fetal Neonatal Ed. 2003; 88(3):F256-7.

Becton Dickinson (BD). First PICC: Estudos técnicos, São Paulo: Centro de Treinamento em Acesso Vascular; 2000.

Bianchi-Sand S. It takes a team to prevent errors: experts call for a team approach to safety. Am J Nurs. 2003;103(12):89-90.

Brasil, Ministério as Saúde, Conselho Regional de Enfermagem (COREN), Resolução RDC n. 258/2001, de 12 de julho de 2000. Dispõe sobre a competência técnica do enfermeiro na Inserção de Cateter Periférico Central (CCIP) [legislação na internet]. Brasília; 2000. [citado 2005 jun, 15], disponível em URL: http://www.corensp.org.br/resol/258

Brasil, Ministério da Saúde, Agência Nacional de Vigilância Sanitária(ANVISA), Resolução RDC n. 45, de 12 de março de 2003. Dispõe sobre o regulamento Técnico de Boas Práticas de Utilização das Soluções Parenterais (SP) em Serviços de Saúde [legislação na Internet]. Brasília; 2003. [citado 2005 jun, 15], disponível em URL: http://www.anvisa.gov.br/legis/resol/2003/rdc/45_03rdc.htm.

Brooker RW, Keenan WJ. Catheter related bloodstream infection following PICC removal in preterm infants. J Perinatol. 2007;27(3):171-4. 
Camara D. Minimizing risks associated with peripeherally inserted central catheters in the NICU. MCN Am J Matern Child Nurs. $2001 ; 26(1): 17-21$.

Center for Disease Control and Prevention(CDC)- Guidelines for the prevention of intravascular catheter-related infections. MMWR. 2002; 51:1-32.

Chaitowitz I, Heng R, Bell K. Managing peripherally inserted central catheter-related venous thrombosis: How I do it. Australas Radiol. 2006; 50(2):132-5.

Chathas MK, Paton JB, Fischer DE. Percutaneous central venous catheterization. Three years' experience in a neonatal intensive care unit. Am J Dis Child. 1990;144(11):1246-50.

Chemaly RF, de Parres JB, Rehm SJ, Adal KA, Lisgaris MV, KatzScott DS, et al. Venous thrombosis associated with peripherally inserted central catheters: a retrospective analysis of the Cleveland Clinic experience. Clin Infect Dis. 2002;34(9):1179-83.

Chen CC, Liang CD, Huang CF, Chung MY. Percutaneous removal of a peripherally inserted central catheter remnant using cardiac catheterization. Pediatr Int. 2006;48(4):430-2.

Chowdhary SK, Parashar K, Buick RG, Gornall P, Corkery JJ. Centralvenous access through the peripheral route in surgical neonates: an audit of 125 consecutive lines from a regional neonatal centre. Pediatr Surg Int. 2001;17(5-6):433-5.

Chlebicki MP, Teo EK. Review of peripherally inserted central catheters in the Singapore acute-care hospital. Singapore Med J. 2003;44(10):531-5.

Chow LM, Friedman JN, Macarthur C, Restrepo R, Temple M, Chait $P G$, et al. Peripherally inserted central catheter (PICC) fracture and embolization in the pediatric population. J Pediatr. 2003;142(2):141-4.

Cloherty JP, Eichenwald EC, Stark AR. Manual de neonatologia. In: Honrubia D, Stark AR. Doenças Respiratórias. $5^{\underline{a}}$ ed. Rio de Janeiro: Guanabara Koogan; 2005. p. 290-6. 
Connolly B, Amaral J, Walsh S, Temple M, Chait P, Stephens D. Influence of arm movement on central tip location of peripherally inserted central catheters (PICCs). Pediatr Radiol. 2006;36(8):845-50.

Conselho Regional de Enfermagem (COREN), ofício $n$. 0426/99/PRSG de 15 de março de 1999. Dispõe sobre a competência técnica do enfermeiro para a inserção do cateter periférico central. [ofício na internet]. São Paulo, 1999. [citado 2005, jun 15] disponível em http://www.corensp.org.br/0426/99

Crawford M, Soukup SM, Woods SS, Deisch P. Peripherally inserted central catheter program. Nurs Clin North Am. 2000;35(2):349-60.

Cunha ML, Lopes CAM, Rugolo LMSS, Chalita LVAS. Significância clínica de estafilococos coagulase-negativa isolados de recémnascidos. J Pediatr (Rio J). 2002;78(4):279-88.

D' Angio CT, McGowan KL, Baumgart S, St Geme J, Harris MC. Surface colonization with coagulase-negative staphylococci in premature neonates. J Pediatr. 1989;114(6):1029-34.

D'Elia C, Correia MS, Oliveira SD, Barbosa NMM. Fístula broncovascular- complicação do cateter venoso central percutâneo em neonato. J Pediatr. (Rio J) 2002;78(4):347-50.

Dinc $L$, Erdil $F$. The effectiveness of an educational intervention in changing nursing practive and preventing catheter-related infection for patients receiving total parenteral nutrition. Int $\mathrm{J}$ Nurs Stud. 2000;37(5):371-9.

Eggimann P, Hugonnet S, Sax H, Harbarth S, Chevrolet JC, Pittet D. Long-term reduction of vascular access associated bloodstream infection. Ann Intern Med. 2005;142(10):875-6.

Evans M, Lentsch D. Percutaneously inserted polyurethane central catheters in the NICU: one unit's experience. Neonatal Netw. 1999;18(6) 37-46.

Fazio Jr J, Carvalho MF, Nogueira PRC, Carvalho WB. Cuidados intensivos no período neonatal. In: Borrelli VLM. Monitorização neonatal. São Paulo: Sarvier; 1999. p. 27-9. 
Ferferbaum R, Delgado EF, Vaz FAC. Suporte nutricional parenteral no recém-nascido. Pediatr Mod. 2000;36(1):117-32.

Ferreira V, Ferrareze MG. Estratégias para prevenção de infecção da corrente sanguínea relacionada a cateter em UTI. Ri-Rev Intensiva. 2006;5(3):152-3.

Fetzer SJ, Manning GP. Safety and efficacy of the POP technique for restoring patency to occluded PIC catheters. Appl Nurs Res. 2004;17(4):297-300.

Foo R, Fujii A, Harris JA, LaMorte W, Moulton S. Complications in tunneled CVL versus PICC lines in very low birth weight infants. J Perinatol. $2001 ; 21(8): 525-30$.

Fong NI, Holtzman SR, Bettmann MA, Bettis SJ. Peripherally inserted central catheters: outcome as a function of the operator. J Vasc Interv Radiol. 2001;12(6):723-9.

Forauer AR, Alonzo M. Change in peripherally inserted central catheter tip position with abduction and adduction of the upper extremity. J Vas Interv Radiol. 2000;11(10):1315-8.

Franck LS, Hummel D, Connell K, Quinn D, Montgomery J. The safety and efficacy of peripheral intravenous catheters in ill neonates. Neonatal Netw. 2001; 20(5):33-8.

Freitas LCM, Raposo LCM, Finoquio RA. Instalação, manutenção e manuseio de cateteres venosos centrais de inserção periférica em pacientes submetidos a tratamento quimioterápico. Rev Bras. Cancerol. 1999;45(1):19-29.

Frey AM, Schears G. Dislodgment rates and impact of securement methods for peripherally inserted central catheters (PICCs) in children. Pediatr Nurs. 2001;27(2):185-9,193.

Fricke BL, Racadio JM, Duckworth T, Donnelly LF, Tamer RM, Johnson ND. Placement of peripherally inserted central catheters without fluoroscopy in children: initial catheter tip position. Radiology. 2005; 234(3):887-92.

Fry C, Aholt D. Local anesthesia prior to the insertion of peripherally inserted central catheters. J Infus Nurs. 2001;24(6):404-8. 
Gaiva MAM, Gomes MMF. Cuidando do neonato: uma abordagem de enfermagem. Goiânia: AB; 2003.

Galloway S, Bodenham A. Long-term central venous access. $\mathrm{Br} \mathrm{J}$ Anaesth. 2004;92(5):722-34.

Gamulka B, Mendoza C, Connolly B. Evaluation of a unique, nurseinserted, peripherally inserted central catheter program. Pediatrics. 2005;115(6):1602-6.

Garland JS, Buck RK, Maloney P, Durkin DM, Toth-Lloyd S, Duffy M, et al. Comparison of $10 \%$ povidine-iodine and $0,5 \%$ chlorhexidine gluconate for the prevention of pheripheral intravenous catheter colonization in neonates: a prospective trial. Pediatr Infect Dis. 1995;14(6):510-6.

Garland JS, Alex CP, Henrickson KJ, McAuliffe TL, Maki DG. A vacomycin-heparin lock solution for prevention of nosocomial bloodstream infection in critically ill neonates with peripherally inserted central venous catheters: a prospective, randomized trial. Pediatrics. 2005;116(2):E198-205.

Geddes LAB, Nichols HA. An overview of peripherally inserted central catheters. Adv Practice Nurs J. 2005;5(3):1-9.

Gomella TL. Neonatologia: manejo, procedimento, problemas no plantão, doenças e farmacologia neonatal. $5^{\underline{a}}$ ed. Porto Alegre: Artmed; 2006.

Griffiths VR, Philpot P. Peripherally inserted central catheters (PICCs): do they have a role in the care of the critically ill patient? Intensive Crit Care Nurs. 2002;18(1):37-47.

Guinsburg R. Avaliação e tratamento da dor no recém-nascido. J. Pediatr. (Rio J). 1999;75(3):149-60.

Guinsburg R, Elias LSDT, Balda RCX. Avaliação da dor no recémnascido. Psychologica. 2004;37(1):79-99.

Hadaway L. Technology of flushing vascular access devices. J Infus Nurs. 2006;29(3):129-45. 
Hoffer EK, Bloch RD, Borsa JJ, Santulli P, Fontaine AB, Francoeur N. Peripherally inserted central catheters with distal versus proximal valves: prospective randomized trial. J Vasc Interv Radiol. $2001 ; 12(10): 1173-7$.

Hyman GS, Cardenas D. Upper-Extremity deep vein Thrombosis associated with peripherally inserted central catheters in acute spinal cord injury: a report of 2 cases. Arch Phys Med Rehabil. 2002; 83(9):1313-6.

Janes M, Kalyn A, Pinelli J, Paes B. A randomized trial comparing peripherally inserted central venous catheters and peripheral intravenous catheters in infants with very low birth weight. J Pediatr Surg. 2000; 35(7):1040-4.

Kamala F, Boo NY, Cheah FC, Birinder K. Randomized controlled trial of heparin for prevention of blockage of peripherally inserted central catheters in neonates. Acta Paediatr. 2002;91(12):1350-6.

Kaye R, Sane SS, Towbin RB. Pediatric intervention: an update-part II. J Vasc Interv Radiol. 2000;11(7):807-22.

Klein MD, Rood K, Graham P. Central venous catheter sepsis in surgical newborns. Pediatr Surg Int. 2003;19(7):529-32.

Kopelman BI, Santos AMN, Goulart AL, Almeida MFB, Miyoshi MH, Guinsburg R. Diagnóstico e tratamento em neonatologia. São Paulo: Atheneu; 2004.

LaRue GD. Efficacy of ultrasonography in peripheral venous canulation. J Intraven Nurs. 2000;23(1):29-34.

Lemyre B, Sherlock R, Hogan D, Gaboury I, Moher D, Blanchard C. How effective is tetracaine $4 \%$ gel, before a peripherally inserted central catheter, in reducing procedural pain in infants: a randomized double-blind placebo controlled trial. BMC Med. 2006;3(4):11.

Liossis G, Bardin C, Papageorgion A. Comparison of risks from percutaneous central venous catheters and peripheral lines in infants of extremely low birth weight: a cohort controlled study of infants < 1000 g. J Mater Fetal Neonatal Med. 2003;13(3):171-4.

Machado AF, Pedreira MLG, Chaud MN. Estudo prospectivo, randomizado e controlado sobre o tempo de permanência de 
cateteres venosos periféricos em crianças, segundo três tipos de curativos. Rev Latino Am Enfermagem. 2005;13(3):291-8.

Macklin D. Removing PICC- Handling such complications as phlebitis and catheter fracture. Am J Nurs. 2000;100(1):52-4.

Mahieu LM, De Muynck AO, leven MM, De Dooy JJ, Goossens HJ, Reempts PJ. Risk factors for central vascular catheter-associated bloodstream infections among patients in a neonatal intensive care unit. J Hosp Infect. 2001;48(2):108-16.

Meeks SL, Ciambotti JM, Rodgers BM, Gordon PV. Extravasation of hyperalimentation into the liver parenchyma from a peripherally inserted central catheter. J Pediatric Surg. 2003;38(4):E8.

Merrell SW, Peatross BG, Grossman MD, Sullivan JJ, Harker WG. Peripherally inserted central venous catheters: Low-risk alternatives for ongoing venous access. West J Med. 1994;160(1):25-30.

Mitsufuji N, Matsuo K, Kakita S, Ikuta H. Extravascular collection of fluid around the vertebra resulting from malpositioning of a peripherally inserted central venous catheter in extremely low birth weight infants. J Perinat Med. 2002;30(4):341-4.

Miura E. Infecção pelo estafilococo coagulase-negativo em recémnascidos: mito ou verdade? J Pediatr (Rio J). 2002;78(4):255-6.

Moureau NL. Using ultrasound to guide PICC insertion. Nursing. 2003;33(12):20.

Murray NA. Evaluation and treatment of thrombocytopenia in the neonatal intensive care unit. Acta Paediatr Suppl. 2002;91(438):74-81.

Nadroo AM, Magid MS, Lin J, Green RS, Holzman IR. Death as a complication of peripherally inserted central catheters in neonates. $J$ Pediatr. 2001;138(4):599-601.

Nadroo AM, Glass RB, Lin J, Green RS, Holzman IR. Changes in upper extremity position cause migration of peripherally inserted central catheters in neonates. Pediatrics. 2002;110(1):131-6.

National Association of Vascular Access Networks (NAVAN): Peripherally inserted central catheters: Workshop manual. San Jose, CA; 1996. 
Nowlen TT, Rosenthal GL, Johnson GL, Tom DJ, Vargo TA. Pericardial effusion and tamponade in infants with central catheters. Pediatrics. 2002;110(1):137-42.

Nuntnarumit $\mathrm{P}$, Pinkaew $\mathrm{O}$, Kitwanwanich $\mathrm{S}$. Predictive values of serial C-reactive protein in neonatal sepsis. J Med Assoc Thai. 2002;85(4): S1151-8.

Oakley C, Wright E, Ream E. The experiences of patients and nurses with a nurse-led peripherally inserted central venous catheter line service. Eur J Oncol Nurs. 2000;4(4):207-18.

Ogilvie JW Jr, Merlin MM. Unsuccessful peripherally inserted central catheter placement. J Vasc Interv Radiol. 2006;17(5):913.

Parikh S, Narayanan V. Misplaced peripherally inserted central catheter: an unusual cause of stroke. Pediatr Neurol. 2004;30(3):2102.

Pereira RM, Costa LP, Miranda ME, Silva AGS. Complicações relativas ao uso de cateteres centrais de inserção periférica em neonatos. Pediatr Mod. 2006;42(5):234-9.

Pérez EEUM, Faunes M, Avaca M, Torres V. Galleguillos J, Solis L, et al. Uso de catéter central insertado periféricamente por vía percutánea en recién nacido. Pediatr Día. 2002;18(1):27-31.

Pettit J. Assessment of Infants with peripeherally inserted central catheters: Part 1. Detecting the most frequently occurring complications. Ad Neonatal Care. 2002;2(6):304-15.

Pezzati M, Filippi L, Chiti G, Dani C, Rossi S, Bertini G, et al. Central venous catheters and cardiac tamponade in preterm infants. Intensive Care Med. 2004;30(12):2253-6.

Pezzi MO. Manual de Cateterização Central de Inserção PeriféricaCCIP/PICC. Porto Alegre: Grupo de estudos do CCIP; 2004.

Phillips LD. Manual de Terapia Intravenosa. $2^{-a}$ ed. Porto Alegre: Artmed;

2001. 
Pigna A, Bachiocco V, Fae M, Cuppini F. Peripherally inserted central venous catheter in preterm newborns: two unusual complications. Paediatr Anaesth. 2004;14(2):184-7.

Pignotti MS, Messineo A, Indolfi G, Donzelli G. Bilateral consolidation of the lungs in a preterm infant: an unusual central venous catheter complication. Paediatr Anaesth. 2004;14(11):957-9.

Polit DF, Beck CT, Hungler BP. Fundamentos de pesquisa em enfermagem. Porto Alegre: Artmed; 2004. Compreensão do delineamento da pesquisa quantitativa, cap.8, p. 163-98.

Posen R, deLemos RA. C-reactive protein levels in the extremely. J Perinatol. 1998;18(2):138-41.

Prestes AC, Guinsburg R, Balda RC, Marba ST, Rugolo LM, Pachi $\mathrm{PR}$, et al. Freqüência do emprego de analgésicos em unidades de terapia intensiva neonatal universitárias. J Pediatr. (Rio J). 2005;81(5):405-10.

Racadio JM, Doellman DA, Johnson ND, Bean JA, Jacobs BR. Pediatric peripherally inserted central catheters: complication rates related to catheter tip location. Pediatrics. 2001;107(2):E28;

Renner C. Polyurethane vs silicone PICC catheters: a brief review of outcomes and characteristics. J Vasc Access Devices. 1998;3(1):1621.

Ryder M. Evidence-based practice in the management of vascular access devices for home parenteral nutrition therapy. J. Parenter Enteral Nutr. 2006;30(1):S82-93, S98-9.

Safdar N, Maki DG. Risk of catheter-related bloodstream infection with peripherally inserted central venous catheters used in hospitalized patients. Chest. 2005;128(2):489-95.

Salis AI, Eclavea A, Johnson MS, Patel NH, Wong DG, Tennery G. Maximal flow rates possible during power injection through currently available PICCs: an in vitro study. J Vasc Interv Radiol. 2004;15(3):275-81.

Sastre JBL, Colomer BF, Cotallo GDC, Aparício AR. Estudio prospectivo sobre catéteres epicutáneos en neonatos. Grupo de Hospitales Castrillo. An Esp Pediatr. 2000;53(2):138-47. 
Schuller DM, Maciel MR, Ichikawa H. Cateter venoso central de inserção periférica em pacientes com acompanhamento ambulatorial: estudo de caso. Nursing (São Paulo). 2005; 8(80):43-5.

Schwengel DA, McGready J, Berenholtz SM, Kozlowski LJ, Nichols DG, Yaster M. Peripherally inserted central catheters: a randomized, controlled, prospective trial in pediatric surgical patients. Anesth Analg. 2004;99(4):1038-43.

Shah P, Shah V. Continuous heparin infusion to prevent thrombosis and catheter occlusion in neonates with peripherally placed percutaneous central venous catheters. Cochrane Database Syst Rev. 2005; 20(3):CD002772.

Shah PS, Kalyn A, Satodia P, Dunn MS, Parvez B, Daneman A, et al. A randomized, controlled trial of heparin versus placebo infusion to prolong the usability of peripherally placed percutaneous central venous catheters (PCVCs) in neonates: the HIP (Heparin Infusion for PCVC) study. Pediatrics. 2007;119(1):E284-91.

Silva GRG, Nogueira MFH. Terapia Intravenosa em recém-nascidos. Orientação para os cuidados de enfermagem. Rio de Janeiro: Cultura Médica; 2004.

Simons SH van, Dijk M, van Lingen RA, Roofthooft D, Duivenvoorden $\mathrm{HJ}$, Jongeneel $\mathrm{N}$, et al. Routine morphine infusion in preterm newborns who received ventilatory support: a randomized controlled trial. JAMA J Am Med Assoc. 2003;290(18):2419-27.

Singhal AK, Mishra S, Bhatnagar S. Recent advances in management of intravascular catheter related Infections. Indian J Med Paediatr Oncol 2005;26(1):31-9.

Smith JR, Friedell ML, Cheatham ML, Martin SP, Cohen MJ, Horowitz JD. Peripherally inserted central catheters revisited. Am J Surg. 1998; 176(2):208-11.

Sociedade Brasileira de Enfermeiros de Terapia Intensiva. (SOBETI). Curso de Qualificação em Inserção, Utilização e Cuidados com Cateter Venoso Central de Inserção Periférica- CCIPNeonatologia/Pediatria. São Paulo, 2004. 
Sola MC, Del Vecchio A, Rimasza LM. Evaluation and treatment of thrombocytopenia in the neonatal intensive care unit. Clin Perinatol. 2000;27(3):655-79.

Sola MC, Del Vecchio A, Edwards TJ, Suttner D, Hutson AD, Christensen RD. The relationship between hematocrit and bleeding time in very low birth weight infants during the first week of life. J Perinatol. $2001 ; 21(6): 368-71$.

Stevens B, McGrath P, Gibbins S, Beyene J, Breau I, Camfield C, et al. Procedural pain in newborns at risk for neurologic impairment. Pain. 2003;105(1-2):27-35.

Tawil KA, Eldemerdash A, Hathlol KA, Laimoun BA. Peripherally inserted central venous catheters in newborn infants: malpositioning and spontaneous correction of catheter tips. Am $\mathrm{J}$ Perinatol. 2006;23(1):37-40.

Toma E. Avaliação do uso do PICC- Cateter Central de Inserção Periférica - em recém-nascidos. Tese (Doutorado) USP. São Paulo; 2004.

Turcotte S, Dube S, Beauchamp G. Peripherally inserted central venous catheters are not superior to central catheters in the acute care of surgical patients on the ward. World J Surg. 2006;30(8):160519.

Unamuno MRDL, Carneiro JJ, Chueire FB, Marchini JS, Suen VMM. Uso de cateteres venosos totalmente implantados para nutrição parenteral: cuidados, tempo de permanência e ocorrência de complicações infecciosas. Rev Nutr. 2005;18(2):261-9.

Vesely TM. Central venous catheter tip position: a continuing controversy. J Vasc Interven Radiol. 2003;14(5):527-34.

Yamamoto AJ, Solomon JA, Soulen MC, Tang J, Parkinson K, Lin R, et al. Sutureless securement device reduces complications of peripherally inserted central venous catheters. J Vasc Interv Radiol. 2002;13(1):77-81.

Waisman D, Weintraub Z, Rotschild A, Bental Y. Myoclonic movements in very low birth weight premature infants associated with midazolam intravenous bolus administration. Pediatrics. 1999; 104(3):576-9.

Wildt SN, Kearns GL, Hop WC, Murry DJ, Abdel-Rahman SM, van den Anker J. Pharmacokinetics and metabolism of intravenous 
midazolam in preterm infants. Clin Pharmacol Ther. 2001;70(6):52531.

Wu ET, Takeuchi M, Imanaka H, Higuchi T, Kagisaki K. Chylothorax as a complication of innominate vein thrombosis induced by a peripherally inserted central catheter. Anaesth. 2006;61(6):584-6. 


\section{ANEXOS \\ MODELO PARA ELABORAÇÃO DE PROTOCOLO CATETER VENOSO CENTRAL DE INSERÇÃO PERIFÉRICA}

\section{$\underline{\text { Requisitos de estrutura e processo }}$}

- Aprovação pela instituição

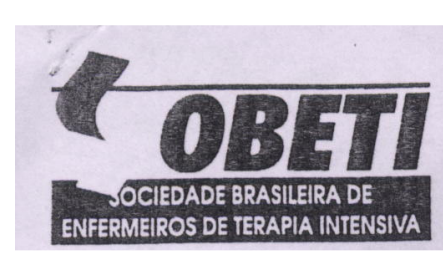

- Assinado pela Diretoria Clínica e Gerência de Enfermagem

- Documentação claramente registrada

- Conter as recomendações

. Estabelecer as responsabilidades

. Estrutura adequada

. Pacientes elegíveis

- Parâmetros clínicos para remoção

- Descrever as técnicas de inserção, cuidados, manutenção e remoção

- Monitorização clínica apropriada

- Descrever as intervenções de enfermagem na ocorrência de complicações

- Não infringir os preceitos éticos-legais da Enfermagem brasileira

\section{Documentacão}

1) Inserção

- Data e hora da inserção

- Nome e identificação do paciente 
- Diagnósticos

- Alergias

- Terapêutica em curso

- Resultados laboratoriais

- Marca do cateter

- Número do lote

- Calibre

- Comprimento total

- Comprimento externo

- Identificação da veia

- Medida basal da circunferência do braço

- Soluções utilizadas

- Utilização de anestésicos

- Números de tentativas

- Dificuldade de inserção

- Intervenções empregadas

- Tolerância do paciente

- Localização da terminação

- Método de confirmação

- Orientações dadas ao paciente, familiares e equipe

- Nome, no COREN, assinatura

2) Troca de curativos

- Data e hora

- Tipo de cateter e localização

- Aspecto do local de inserção e região adjacente

- Medida da circunferência do braço

- Tipo de curativo realizado

- Medida do comprimento externo do cateter

- Respostas do paciente ao procedimento

- Orientações dadas ao paciente

- Nome, no COREN, assinatura

3) Lavagem do cateter

- Data e hora

- Tipo de cateter

- Lumens lavados

- Presença/ausência de retorno sanguíneo

- Razão da lavagem

- Dosagem de heparina utilizada

- Nome, no COREN, assinatura

4) Desobstrução

- Data e hora da identificação do mau funcionamento

- Localização do cateter

- Condições da inserção 
- Identificar quais lumens foram tratados

- Identificar as medicações e soluções utilizadas para tratar o cateter, quantidades utilizadas, $n^{\circ}$ de repetições em cada lúmen

- Descrever as respostas do paciente ao tratamento

- Descrever as orientações dadas ao paciente

- Nome, no COREN, assinatura

5) Remoção do cateter

- Data e hora da remoção

- Motivo da remoção

- Aspectos do cateter

- Comprimento total do cateter

- Respostas do paciente ao procedimento

- Nome, no COREN, assinatura

\section{FORMULARIO DE COLETA DE DADOS}

1) Número do formulário:

2) Registro hospitalar:

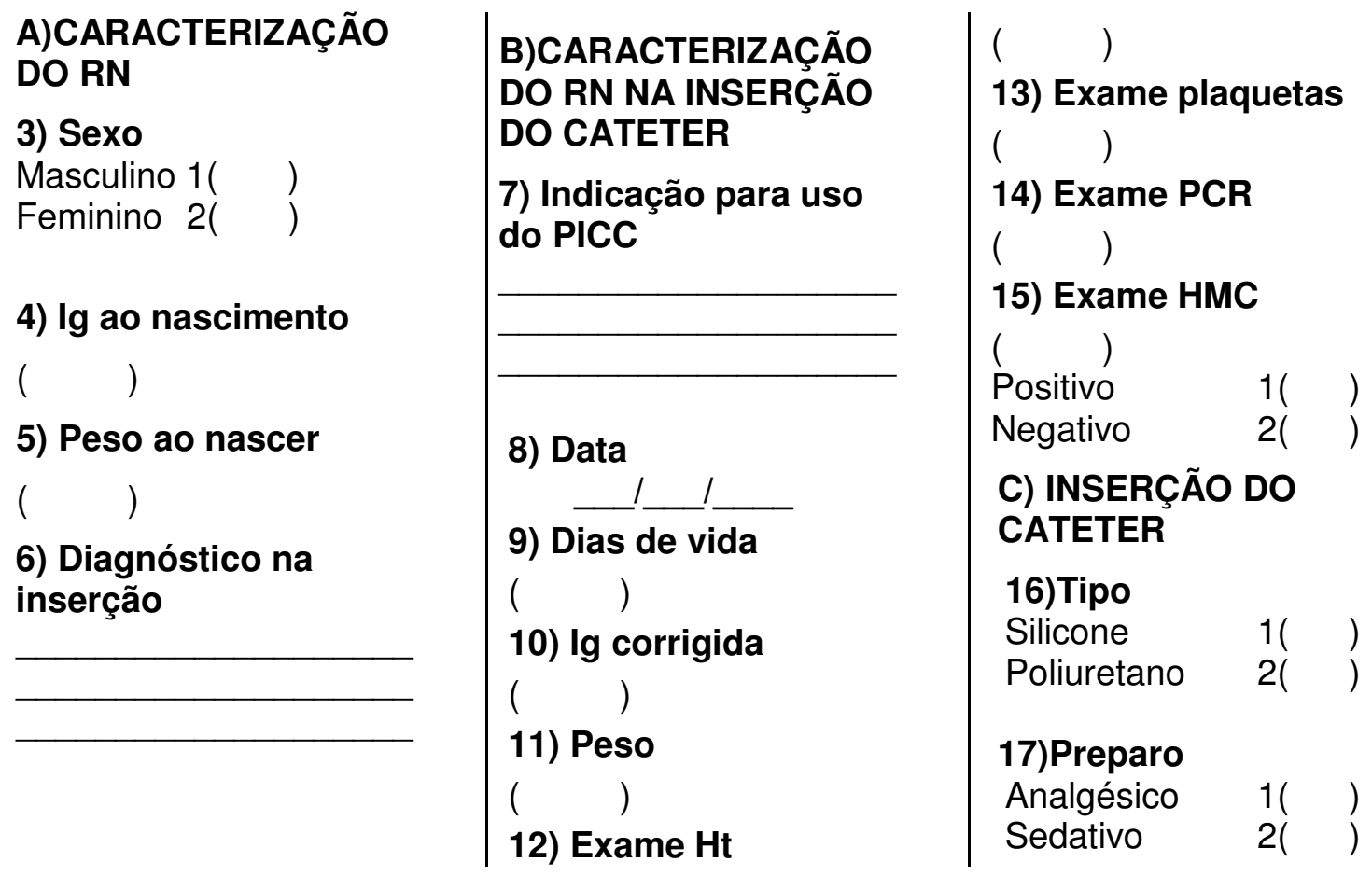


18a) Qual

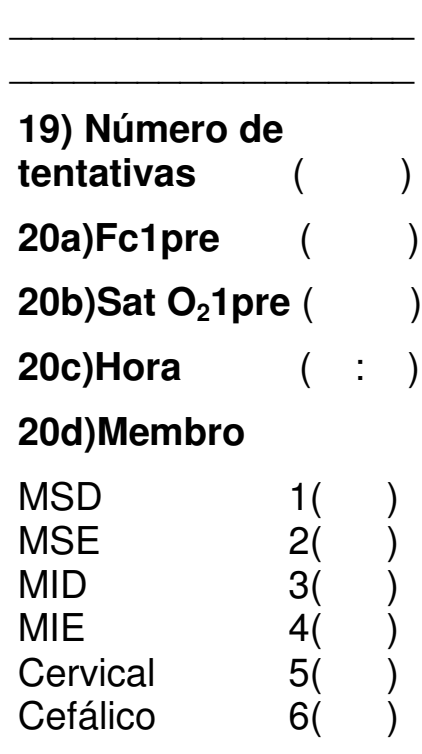

20e) Circunferência

20f) Veia

Basílica

Cefálica

Axilar

Cubital

Arco dorsal da mão5(

Jugular externa 6( )

Femural

$7(\quad)$

Grande safena 8( )

Pequena safena 9( )

Arco dorsal do pé 10( )

Auricular posterior 11( )

Temporal 12( )

21) Êxito Primeira

Sim

Não

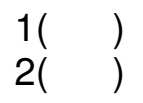

Se não obteve êxito preencha os motivos

Se obteve êxito preencha sempre a alternativa número três

\section{Motivos}

21a) Oclusão do introdutor

Sim

Não
Êxito

3( )

21b) Transfixação venosa

Sim

Não

Êxito

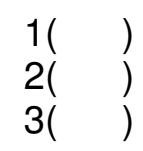

21c) Punção arterial

$\begin{array}{lll}\text { Sim } & 1(\quad) \\ \text { Não } & 2(\quad) \\ \text { Êxito } & 3(\quad)\end{array}$

\section{1d) Vasoespasmo}

Sim

Não

Êxito

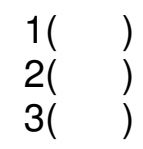

21e) Posição do RN

Sim

Não

Êxito

$1(\quad)$
$2(\quad)$
$3(\quad)$

21f) Medida inadeq.

Sim
Não
Exxito

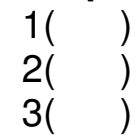

21g) Fragilidade vasc.

Sim

Não

Exxito

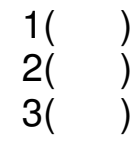

21h) Fechamento de válvula

Sim

Não

Êxito

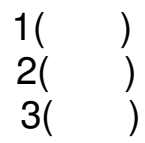

\section{1i)Outros}

Sim

Não

Êxito

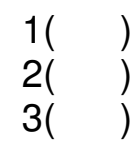

21j)Se outros Qual
22a)Fc1pós

22b)Sat $\mathrm{O}_{2} 1$ pós(

22c)Hora da retirada do introdutor ( : )

23) Intercorrências Sim

Não

Se houve intercorrências preencha quais nos campos seguintes; se não obteve intercorrências preencha o campo da alternativa três

Intercorrências primeira

23a) Bifurcação da veia

Sim

Não

Sem interc.

23b) Hematoma

Sim

Não

Sem interc.

$1(\quad)$
$2(\quad)$
$3(\quad)$

23c) Arritmia Cardíaca

Sim

Não

Sem interc. 3( )

23d) Ponta mal localizada

Sim

Não

Sem interc. $3(\quad)$

23e) Embolia

Sim

$\begin{array}{lll}\text { Não } & 2(\quad) \\ \text { Sem interc. } & 3(\quad)\end{array}$

23f)Alteração da visc. sangüínea

Sim

Não

Sem interc. $3(\quad)$ 
23g) Outros

Sim

Não

$1(\quad)$

2)

Sem interc. 3( )

23h)Se outros Qual

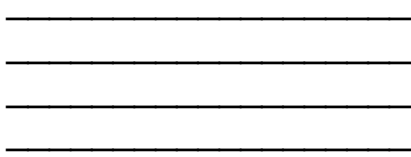




SEGUNDA PUNÇÃO
$\begin{array}{lll}\text { 24a)Fc1pre } & (\quad) \\ \text { 24b)Sat O } & \text { 1pre( } & ) \\ \text { 24c)Hora } & (\quad: & ) \\ \text { 24d)Membro } & & \\ \text { MSD } & 1( & ) \\ \text { MSE } & 2( & ) \\ \text { MID } & 3( & ) \\ \text { MIE } & 4( & ) \\ \text { Cervical } & 5( & ) \\ \text { Cefálico } & 6( & )\end{array}$

24e) Circunferência

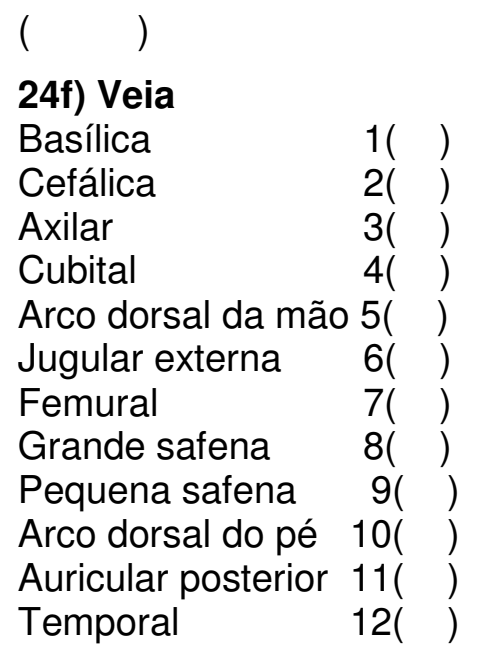

25) Êxito segunda

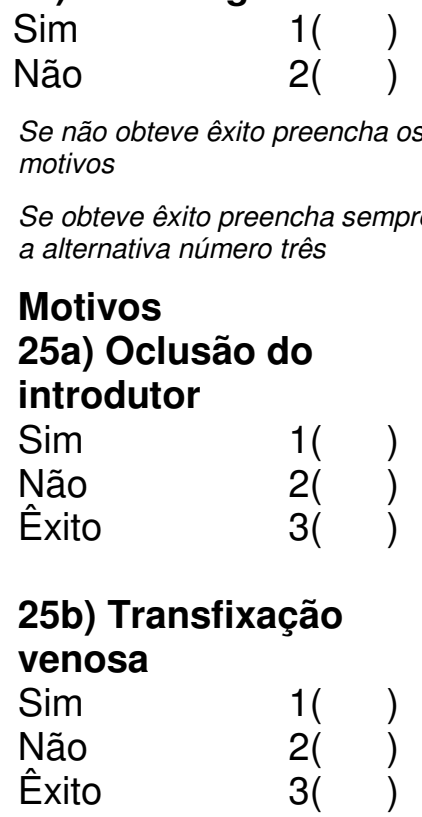

25c) Punção arterial

$\begin{array}{lll}\text { Sim } & 1(\quad) \\ \text { Não } & 2(\quad) \\ \text { Ẽxito } & 3(\quad)\end{array}$

25d) Vasoespasmo

Sim

Não

Êxito

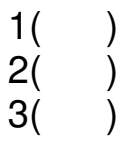

25e) Posição do RN

Sim

Não

Êxito

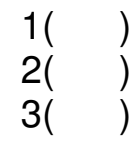

25f) Medida inadeq.

Sim

Não

Êxito

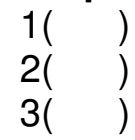

25g) Fragilidade vasc.

$\begin{array}{lll}\text { Sim } & 1(\quad) \\ \text { Não } & 2(\quad) \\ \text { Êxito } & 3(\quad)\end{array}$

25h) Fechamento de válvula

Sim

Não

Êxito

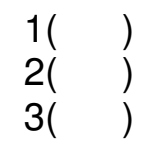

\section{5i)Outros}

Sim

Não

Êxito

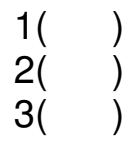

25j)Se outros Qual

26a)Fc1pós

26b)Sat $O_{2} 1$ pós(

26c)Hora da retirada do introdutor $($ : )
27) Intercorrências segunda

Sim

Não

Se houve intercorrências preencha quais nos campos seguintes; se não obteve intercorrências preencha o campo da alternativa três

\section{Intercorrências}

27a) Bifurcação da veia

Sim

Não

Sem interc. $3(\quad)$

27b) Hematoma

Sim

Não

$\begin{array}{ll}1( & ) \\ 2( & ) \\ 3( & )\end{array}$

Sem interc. $3(\quad)$

27c) Arritmia Cardíaca Sim

Não

$1(\quad)$

Sem interc. $3(\quad)$

27d) Ponta mal localizada

Sim

Não

Sem interc. $3($ )

27e) Embolia

Sim

Não

Sem interc. $3(\quad)$

27f) Alteração da visc. sangüínea

Sim

Não

Sem interc. $3(\quad)$

27g) Outros

$\begin{array}{lll}\text { Sim } & 1(\quad) \\ \text { Não } & 2(\quad) \\ \text { Sem interc. } & 3(\quad)\end{array}$

27h)Se outros Qual 


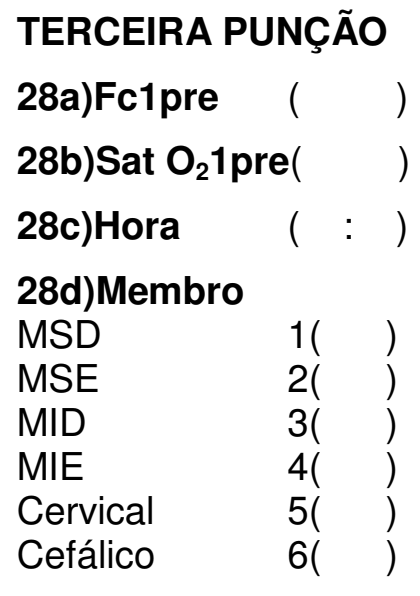

28e) Circunferência

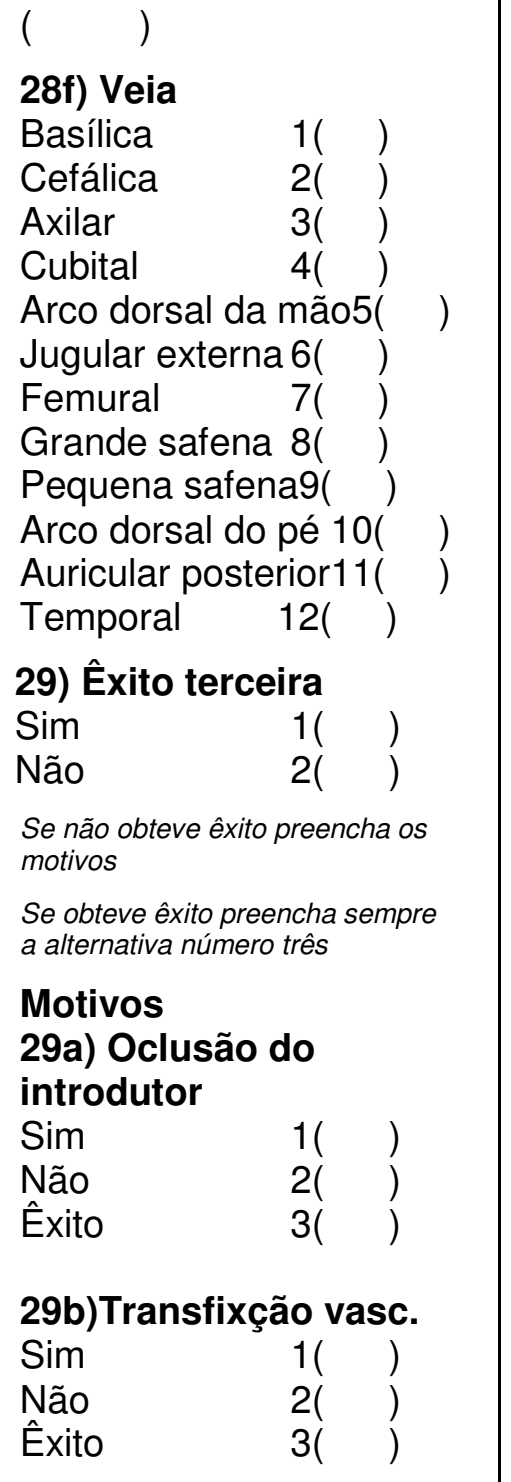

29c) Punção arterial

$\begin{array}{lll}\text { Sim } & 1(\quad) \\ \text { Não } & 2(\quad) \\ \text { Êxito } & 3(\quad)\end{array}$

29d) Vasoespasmo

Sim

Não

Êxito

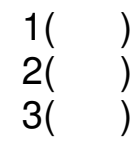

29e) Posição do RN

Sim

Não

Êxito

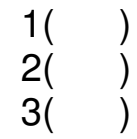

29f)Medida inadeq.

Sim
Não
Ẽxito

$1(\quad)$
$2(\quad)$
$3(\quad)$

29g) Fragilidade vasc.

$\begin{array}{lll}\text { Sim } & 1(\quad) \\ \text { Não } & 2(\quad) \\ \text { Êxito } & 3(\quad)\end{array}$

29h) Fechamento de válvula

Sim

Não

Êxito

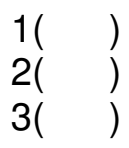

\section{9i)Outros}

$\begin{array}{lll}\text { Sim } & 1(\quad) \\ \text { Não } & 2(\quad) \\ \text { Exxito } & 3(\quad)\end{array}$

29j)Se outros Qual

30a)Fc1pós 30b)Sat $\mathrm{O}_{2} 1$ pós( ) 30c)Hora da retirada do introdutor $($ : )
31) Intercorrências terceira

Sim

Não

Se houve intercorrências preencha quais nos campos seguintes; se não obteve intercorrências preencha o campo da alternativa três

\section{Intercorrências}

31a) Bifurcação da veia

Sim

Não

Sem interc. 3( )

31b) Hematoma

$\begin{array}{lll}\text { Sim } & 1(\quad) \\ \text { Não } & 2(\quad) \\ \text { Sem interc. } & 3(\quad)\end{array}$

31c) Arritmia Cardíaca Sim

Não

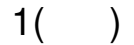

Sem interc. 3( )

31d) Ponta mal localizada

Sim

Não

Sem interc. 3( )

31e) Embolia

Sim

Não

$1(\quad)$

Sem interc. 3( )

31f) Alteração da visc. sangüínea

Sim

Não

Sem interc. $3(\quad)$

31g) Outros

$\begin{array}{lll}\text { Sim } & 1(\quad) \\ \text { Não } & 2(\quad) \\ \text { Sem interc. } & 3(\quad)\end{array}$

31h)Se outros Qual 


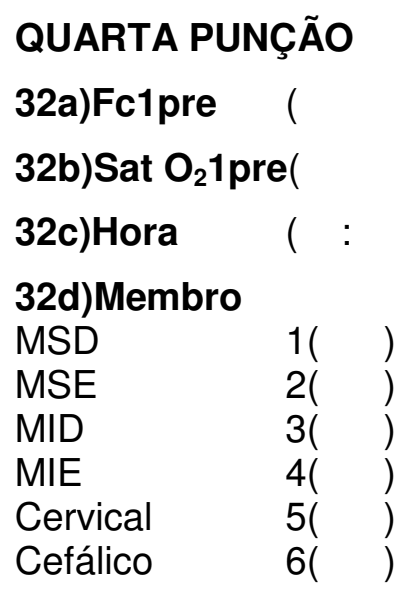

32e) Circunferência

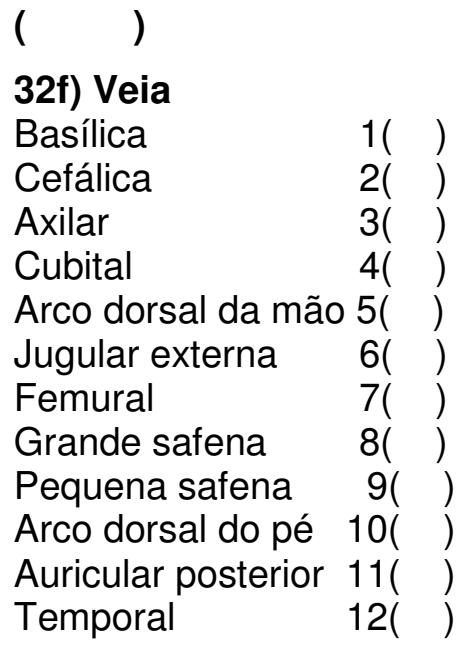

33) Êxito quarta

$\begin{array}{ll}\text { Sim } & 1(\text { ) } \\ \text { Não } & 2()\end{array}$

Se não obteve êxito preencha os motivos

Se obteve êxito preencha sempre a alternativa número três

\section{Motivos}

33a) Oclusão do introdutor

Sim

Não

Êxito

$\begin{array}{ll}1( & ) \\ 2( & ) \\ 3( & )\end{array}$

33b) Transfixação venosa

Sim

Não

Êxito 33c) Punção arterial

Sim

Não

Êxito

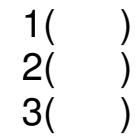

33d) Vasoespasmo

Sim

Não

Êxito

$1(\quad)$
$2(\quad)$
$3(\quad)$

33e) Posição do RN

Sim

Não

Êxito

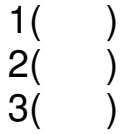

33f) Medida inadeq.

Sim

Não

Êxito

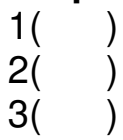

33g) Fragilidade vasc.

Sim

Não

Êxito

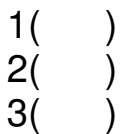

33h) Fechamento de válvula

Sim

Não

Êxito

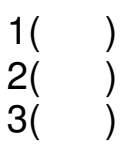

\section{3i)Outros}

$\begin{array}{lll}\text { Sim } & 1(\quad) \\ \text { Não } & 2(\quad) \\ \text { Êxito } & 3(\quad)\end{array}$

33j)Se outros Qual

34a)Fc1pós

34b)Sat $\mathrm{O}_{2} 1$ pós ( )

34c)Hora da retirada do introdutor ( : )

35) Intercorrências quarta

Sim

Não
Se houve intercorrências preencha quais nos campos seguintes; se não obteve intercorrências preencha o campo da alternativa três

\section{Intercorrências}

35a) Bifurcação da veia

Sim

Não

Sem interc. 3(

35b) Hematoma

Sim

Não

Sem interc. $3($ )

35c) Arritmia Cardíaca

Sim

Não

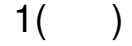

Sem interc. 3( )

35d) Ponta mal

localizada

Sim

Não

Sem interc. 3()

\section{5e) Embolia}

Sim

Não

$1(\quad)$

Sem interc. $3(\quad)$

35f) Alteração da visc. sangüínea

Sim

Não

Sem interc. 3( )

$35 g)$ Outros

Sim

Não

Sem interc. 3( )

35h)Se outros Qual 


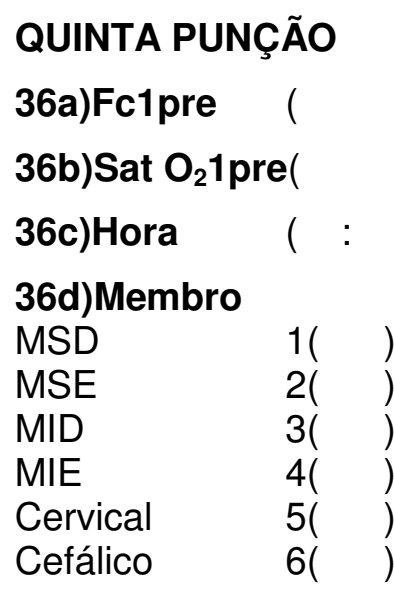

36e) Circunferência

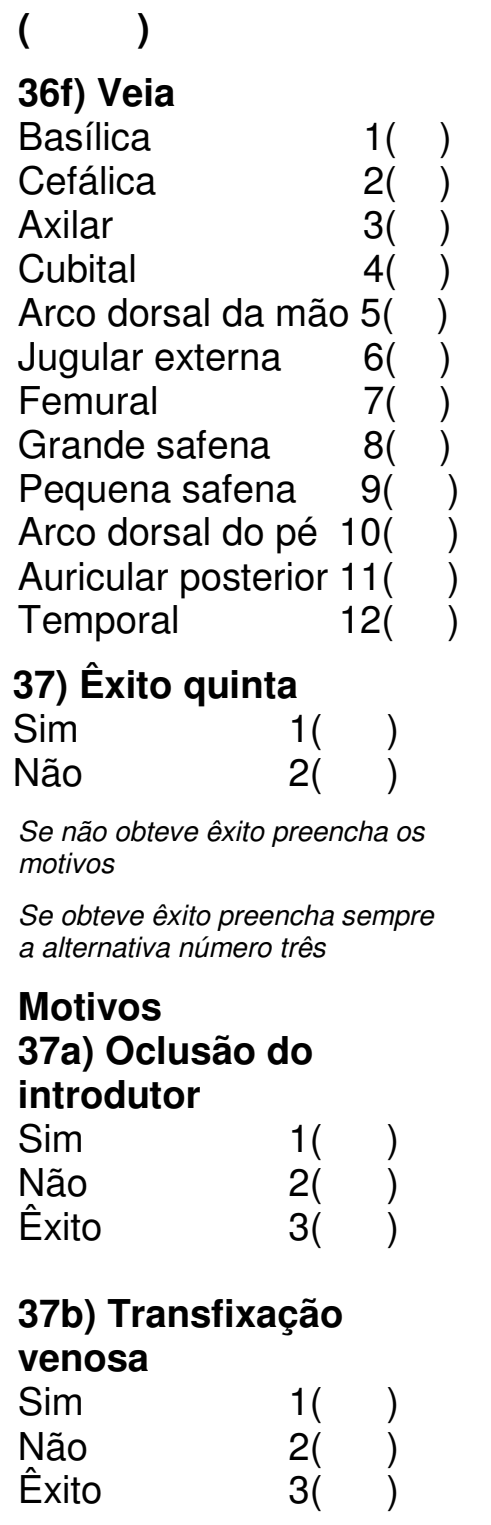

37c) Punção arterial

$\begin{array}{lll}\text { Sim } & 1(\quad) \\ \text { Não } & 2(\quad) \\ \text { Êxito } & 3(\quad)\end{array}$

37d) Vasoespasmo

$\begin{array}{lll}\text { Sim } & 1(\quad) \\ \text { Não } & 2(\quad) \\ \text { Êxito } & 3(\quad)\end{array}$

37e) Posição do RN

$\begin{array}{lll}\text { Sim } & 1(\quad) \\ \text { Não } & 2(\quad) \\ \text { Exxito } & 3(\quad)\end{array}$

37f) Medida Inadeq.

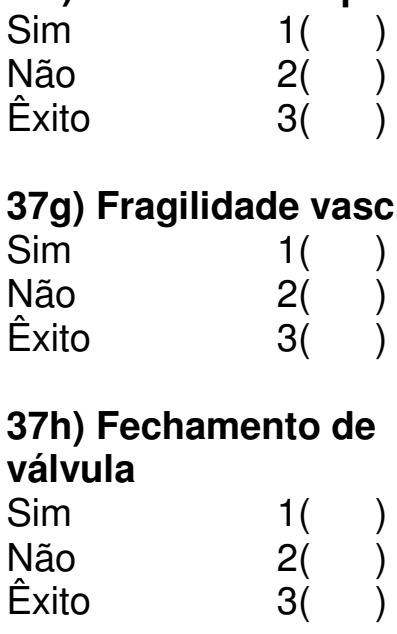

37i)Outros

$\begin{array}{lll}\text { Sim } & 1(\quad) \\ \text { Não } & 2(\quad) \\ \text { Êxito } & 3(\quad)\end{array}$

37j)Se outros Qual

38a)Fc1pós ( )
38b)Sat $\mathrm{O}_{2}$ 1pós(
38c)Hora da retirada
do introdutor $(: \quad)$
39) Intercorrências
quinta
Sim
Não

Se houve intercorrências preencha quais nos campos seguintes; se não obteve intercorrências preencha $o$ campo da alternativa três

\section{Intercorrências}

39a) Bifurcação da veia

Sim

Não

Sem interc. 3( )

39b) Hematoma

Sim

Não

$1(\quad)$

Sem interc. $3(\quad)$

39c) Arritmia Cardíaca

Sim

Não

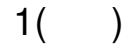

Sem interc. $3(\quad)$

39d) Ponta mal

localizada

Sim

Não

Sem interc. 3( )

39e) Embolia

Sim

Não

$1(\quad)$

Sem interc. $3(\quad)$

39f) Alteração da visc. sangüínea

Sim

Não

Sem interc. 3( )

$39 g)$ Outros

Sim

Não

Sem interc. 3()

39h)Se outros Qual 


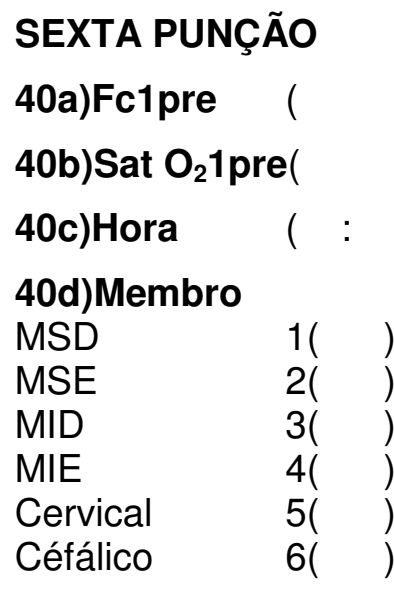

40e) Circunferência

\begin{tabular}{|c|c|}
\hline \\
\hline \multicolumn{2}{|l|}{ 40f) Veia } \\
\hline Basílica & 1( \\
\hline Cefálica & 2( \\
\hline Axilar & 3( \\
\hline Cubital & 4( \\
\hline Arco dorsal da mão & 5( \\
\hline Jugular externa & 61 \\
\hline Femural & 7( \\
\hline Grande safena & 8( \\
\hline Pequena safena & 9 \\
\hline Arco dorsal do pé & 10 \\
\hline Auricular posterior & 11( \\
\hline Temporal & 12( \\
\hline
\end{tabular}

41) Êxito sexta

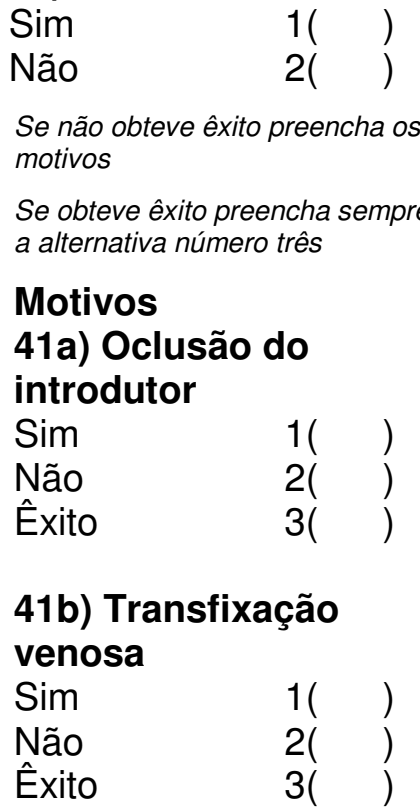

41c) Punção arterial

Sim

Não

Êxito

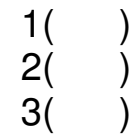

41d) Vasoespasmo

Sim

Não

Êxito

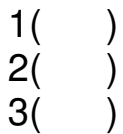

41e) Posição do RN

Sim

Não

Êxito

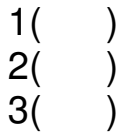

41f)Medida Inadeq.

Sim

Não

Êxito

$1(\quad)$
$2(\quad)$
$3(\quad)$

41g) Fragilidade vas.

Sim

Não

Êxito

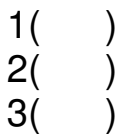

41h) Fechamento de válvula

Sim

Não

Êxito

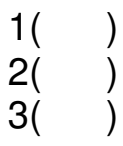

\section{1i)Outros}

$\begin{array}{lll}\text { Sim } & 1(\quad) \\ \text { Não } & 2(\quad) \\ \text { Êxito } & 3(\quad)\end{array}$

41j)Se outros Qual

\section{2a)Fc1pós}

42b)Sat $\mathrm{O}_{2} 1$ pós

42c)Hora da retirada do introdutor $(:)$
43) Intercorrências sexta

Sim

Não

Se houve intercorrências preencha quais nos campos seguintes; se não obteve intercorrências preencha o campo da alternativa três

\section{Intercorrências}

43a) Bifurcação da veia

Sim

Não

Sem interc. 3( )

43b) Hematoma

Sim

Não

Sem interc. $3($ )

43c) Arritmia Cardíaca Sim

Não

$1(\quad)$

Sem interc. 3( )

43d) Ponta mal localizada

Sim

Não

Sem interc. 3( )

43e) Embolia

Sim

Não

Sem interc. $3($ )

43f)Alteração da visc. sangüínea

Sim

Não

Sem interc. 3( )

43g) Outros

$\begin{array}{lll}\text { Sim } & 1(\quad) \\ \text { Não } & 2(\quad) \\ \text { Sem interc. } & 3(\quad)\end{array}$

43h)Se outros Qual 


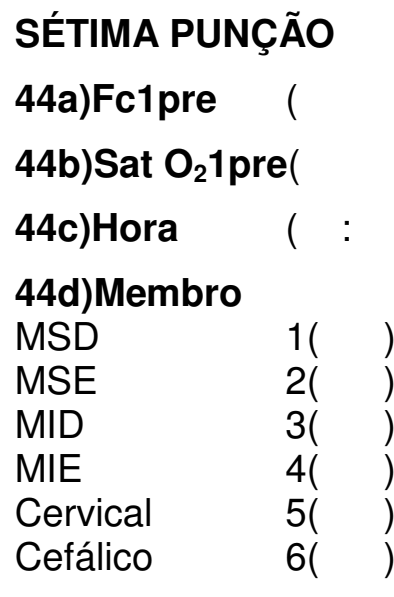

44e) Circunferência

$\begin{array}{lrl}(\quad) & & \\ \text { 44f) Veia } & & \\ \text { Basílica } & 1(\quad) \\ \text { Cefálica } & 2(\quad) \\ \text { Axilar } & 3(\quad) \\ \text { Cubital } & 4(\quad) \\ \text { Arco dorsal da mão } & 5(\quad) \\ \text { Jugular externa } & 6(\quad) \\ \text { Femural } & 7(\quad) \\ \text { Grande safena } & 8(\quad) \\ \text { Pequena safena } & 9(\quad) \\ \text { Arco dorsal do pé } & 10(\quad) \\ \text { Auricular posterior } & 11(\quad) \\ \text { Temporal } & 12(\quad)\end{array}$

45) Êxito sétima

\begin{tabular}{|c|c|}
\hline $\begin{array}{l}\text { Sim } \\
\text { Não }\end{array}$ & $\begin{array}{l}1( \\
2(\end{array}$ \\
\hline \multicolumn{2}{|c|}{ Se não obteve êxito preencha os } \\
\hline \multicolumn{2}{|c|}{$\begin{array}{l}\text { Se obteve êxito preencha semp } \\
\text { a alternativa número três }\end{array}$} \\
\hline \multicolumn{2}{|c|}{$\begin{array}{l}\text { Motivos } \\
45 a) \text { Oclusão do } \\
\text { introdutor }\end{array}$} \\
\hline Sim & 1( \\
\hline Não & 2( \\
\hline Exxito & 31 \\
\hline \multicolumn{2}{|c|}{$\begin{array}{l}45 b) \text { Transfixação } \\
\text { venosa }\end{array}$} \\
\hline Sim & \\
\hline Não & \\
\hline Exito & \\
\hline
\end{tabular}

45c) Punção arterial

$\begin{array}{lll}\text { Sim } & 1(\quad) \\ \text { Não } & 2(\quad) \\ \text { Êxito } & 3(\quad)\end{array}$

45d) Vasoespasmo

Sim

Não

Êxito

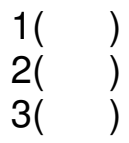

45e) Posição do RN

Sim

Não

Êxito

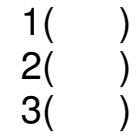

45f) Medida inadeq.

Sim

Não

Êxito

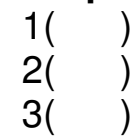

45g) Fragilidade vasc.

Sim

Não

Êxito

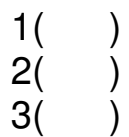

45h) Fechamento de válvula

Sim

Não

Êxito

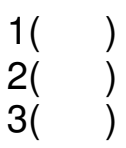

\section{5i)Outros}

$\begin{array}{lll}\text { Sim } & 1(\quad) \\ \text { Não } & 2(\quad) \\ \text { Êxito } & 3(\quad)\end{array}$

\section{5j)Se outros Qual}

46a)Fc1pós

46b)Sat $\mathrm{O}_{2} 1$ pós(

46c)Hora da retirada do introdutor ( : )
47) Intercorrências sétima

Sim

Não

Se houve intercorrências preencha quais nos campos seguintes; se não obteve intercorrências preencha 0 campo da alternativa três

\section{Intercorrências}

47a) Bifurcação da veia

Sim

Não

Sem interc. 3( )

47b) Hematoma

Sim

Não

Sem interc. $3($ )

47c) Arritmia Cardíaca Sim

Não

$1(\quad)$

Sem interc. 3( )

47d) Ponta mal localizada

Sim

Não

Sem interc. 3()

47e) Embolia

Sim

Não

Sem interc. 3( )

47f) Alteração da visc. sangüínea

Sim

Não

Sem interc. 3()

47g) Outros

$\begin{array}{lll}\text { Sim } & 1(\quad) \\ \text { Não } & 2(\quad) \\ \text { Sem interc. } & 3(\quad)\end{array}$

47h)Se outros Qual 
OITAVA PUNÇÃO

48a)Fc1pre ( )

48b)Sat $O_{2} 1$ pre ( )

48c)Hora ( : )

48d)Membro

MSD

MSE

MID

MIE

Cervical

Cefálico

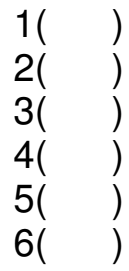

48e) Circunferência

\begin{tabular}{|c|c|}
\hline \multicolumn{2}{|l|}{$\begin{array}{l}(\quad) \\
\text { 48f) Veia }\end{array}$} \\
\hline & \\
\hline $\begin{array}{l}\text { Basílica } \\
\text { Cefálica }\end{array}$ & \\
\hline Axilar & \\
\hline Cubital & 4( \\
\hline Arco dorsal da mão & 05( \\
\hline Jugular externa & \\
\hline =emural & 7( \\
\hline Grande safena & 8( \\
\hline quena safena & 9( \\
\hline orsal do pé 1 & 10( \\
\hline Auricular posterior 1 & 11( \\
\hline nporal & 12( \\
\hline
\end{tabular}

49) Êxito oitava

\begin{tabular}{|c|c|}
\hline $\begin{array}{l}\text { Sim } \\
\text { Não }\end{array}$ & 2( \\
\hline \multicolumn{2}{|c|}{$\begin{array}{l}\text { Se não obteve êxito preencha } \\
\text { motivos }\end{array}$} \\
\hline \multicolumn{2}{|c|}{$\begin{array}{l}\text { Se obteve exito preencha sem } \\
\text { a alternativa número três }\end{array}$} \\
\hline \multicolumn{2}{|c|}{$\begin{array}{l}\text { Motivos } \\
49 a) \text { Oclusão do } \\
\text { introdutor }\end{array}$} \\
\hline $\operatorname{Sim}$ & 1( \\
\hline $\begin{array}{l}\text { Não } \\
\text { Êxito }\end{array}$ & $\begin{array}{l}2( \\
3(\end{array}$ \\
\hline \multicolumn{2}{|c|}{$\begin{array}{l}\text { 49b) Transfixaçãc } \\
\text { venosa }\end{array}$} \\
\hline & \\
\hline $\begin{array}{l}\text { Não } \\
\text { Êvito }\end{array}$ & 2( \\
\hline
\end{tabular}

49c) Punção arterial

Sim

Não

Êxito

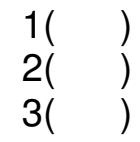

49d) Vasoespasmo

Sim

Não

Êxito

$1(\quad)$

2( )

3( )

49e) Posição do RN

Sim

Não

Êxito

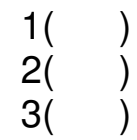

49f) Medida Inadeq.

Sim

Não

Êxito

$\begin{array}{ll}1( & ) \\ 2( & ) \\ 3( & )\end{array}$

49g) Fragilidade vasc.

Sim

Não

Exito

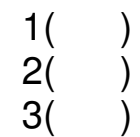

49h) Fechamento de válvula

Sim

Não

Êxito

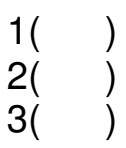

\section{9i)Outros}

$\begin{array}{lll}\text { Sim } & 1(\quad) \\ \text { Não } & 2(\quad) \\ \text { Exxito } & 3(\quad)\end{array}$

\section{9j)Se outros Qual}

50a)Fc1pós

50b)Sat $\mathrm{O}_{2} 1$ pós(

$50 \mathrm{c})$ Hora da retirada do introdutor ( : )
51) Intercorrências oitava

Sim

Não

Se houve intercorrências preencha quais nos campos seguintes; se não obteve intercorrências preencha o campo da alternativa três

\section{Intercorrências}

51a) Bifurcação da veia

Sim

Não

Sem interc. 3( )

51b) Hematoma

Sim

Não

Sem interc. $3(\quad)$

51c) Arritmia Cardíaca

Sim

Não

$1(\quad)$

Sem interc. 3( )

51d) Ponta mal localizada

Sim

Não

Sem interc. $3(\quad)$

51e) Embolia

Sim

Não

Sem interc. 3( )

51f) Alteração da visc. sangüínea

Sim

Não

Sem interc. $3(\quad)$

51g) Outros

$\begin{array}{lll}\text { Sim } & 1(\quad) \\ \text { Não } & 2(\quad) \\ \text { Sem interc. } & 3(\quad)\end{array}$

51h)Se outros Qual 
NONA PUNÇÃO

52a)Fc1pre ( )

52b)Sat $\mathrm{O}_{2} 1$ pre( )

52c)Hora

52d)Membro

MSD

MSE

MID

MIE

Cervical

Cefálico

52e) Circunferência

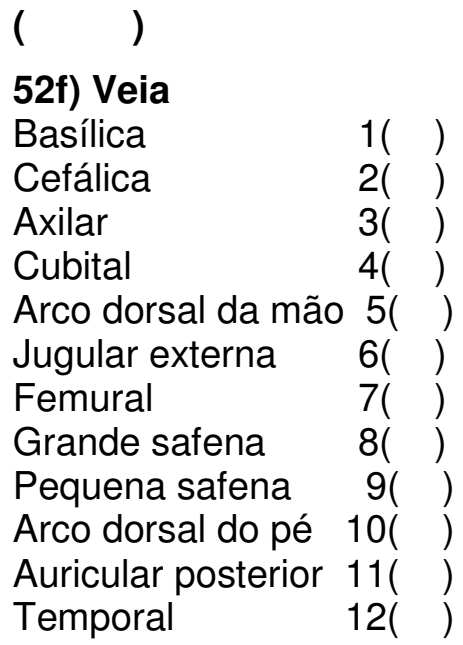

53) Êxito nona

$\begin{array}{ll}\text { Sim } & 1(\quad) \\ \text { Não } & 2(\quad)\end{array}$

Se não obteve êxito preencha os motivos

Se obteve êxito preencha sempre a alternativa número três

\section{Motivos}

53a) Oclusão do

introdutor

Sim

Não

Êxito

$\begin{array}{ll}1( & ) \\ 2( & ) \\ 3( & )\end{array}$

53b) Transfixação

venosa

Sim

Não

Êxito 53c) Punção arterial

$\begin{array}{lll}\text { Sim } & 1(\quad) \\ \text { Não } & 2(\quad) \\ \text { Êxito } & 3(\quad)\end{array}$

53d) Vasoespasmo

Sim

Não

Êxito

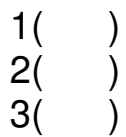

53e) Posição do RN

Sim

Não

Êxito

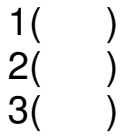

53f) Medida inadeq.

Sim

Não

Êxito

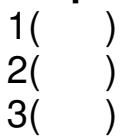

53g) Fragilidade venosa

Sim

Não

Êxito

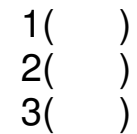

53h) Fechamento de válvula

Sim

Não

Êxito

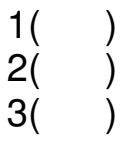

\section{3i)Outros}

Sim

Não

Êxito

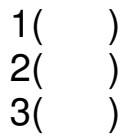

53j)Se outros Qual

54a)Fc1pós

54b)Sat $\mathrm{O}_{2} 1$ pós(

54c)Hora da retirada do introdutor ( : )
55) Intercorrências nona

Sim

Não

Se houve intercorrências preencha quais nos campos seguintes; se não obteve intercorrências preencha 0 campo da alternativa três

\section{Intercorrências}

55a) Bifurcação da veia

Sim

Não

Sem interc. $3(\quad)$

55b) Hematoma

Sim

Não

$\begin{array}{ll}1( & ) \\ 2( & ) \\ 3( & )\end{array}$

Sem interc. $3(\quad)$

55c) Arritmia Cardíaca Sim

Não

Sem interc. 3( )

55d) Ponta mal localizada

Sim

Não

Sem interc. $3(\quad)$

55e) Embolia

Sim

Não

$1(\quad)$

Sem interc. $3(\quad)$

55f)Alteração da visc. sangüínea

Sim

Não

Sem interc. 3( )

55g) Outros

Sim

Não

Sem interc. 3()

$55 \mathrm{~h})$ Se outros Qual 


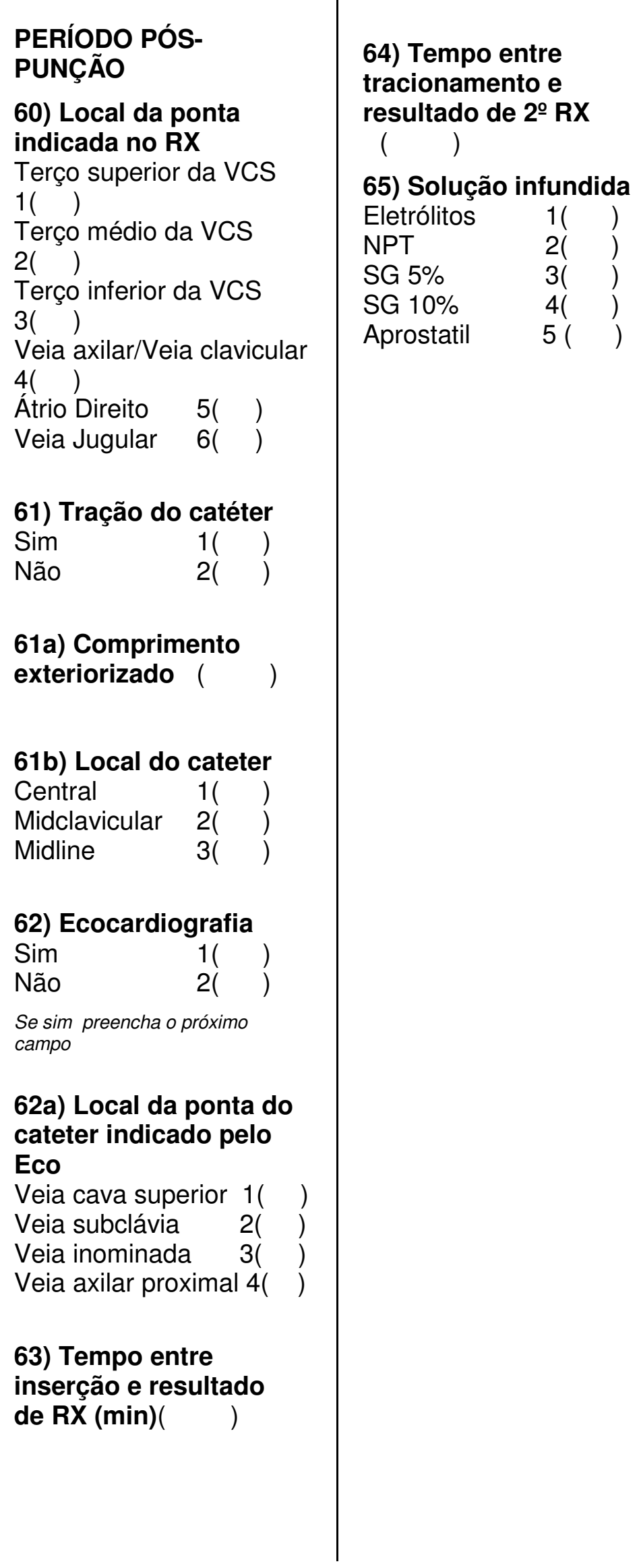




\section{MANUTENÇÃO DO CATETER \\ Primeiro curativo}

170) Data

171) Anti-séptico

Clorexid.álcool. a 0,5\%

$1(\quad)$

PVPI Tópico 2( ～）

172) Tipo de curativo

Fita estéril c/ transp.1(

Fita estéril c/ gaze 2( )

173) Solução infundida

Eletrólitos

NPT

SG $5 \%$

SG $10 \%$

Drogas vasoativas

Drogas sedativas

Aprostadil

1()
2()
3()
4()
5()
6()
$7(\quad)$

174) Uso de ATB

Sim

Não

$$
\begin{array}{ll}
1(\quad) \\
2()
\end{array}
$$

CARACTERÍSTICAS

OBSERVADAS NO

CURATIVO

175a) Permeabilidade

Sim

Não<smiles>CNC[Te][Te]</smiles>

175b) Uso de Tala

Sim

Não<smiles>[Te][Te][Tl]</smiles>

175c) Endurecimento

Sim

Não<smiles>[Te][Te]CI</smiles>

175d) Hematoma

Sim

Não

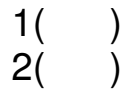

175e) Secreção

Sim

Não 175f) Hiperemia

$\begin{array}{ll}\text { Sim } & 1(\quad) \\ \text { Não } & 2(\quad)\end{array}$

175g) Presença de dobras

Sim

Não

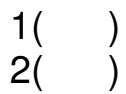

175h) outros

Sim

Não

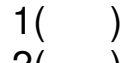

Se outros preencha o próximo campo quais

175ha) Quais

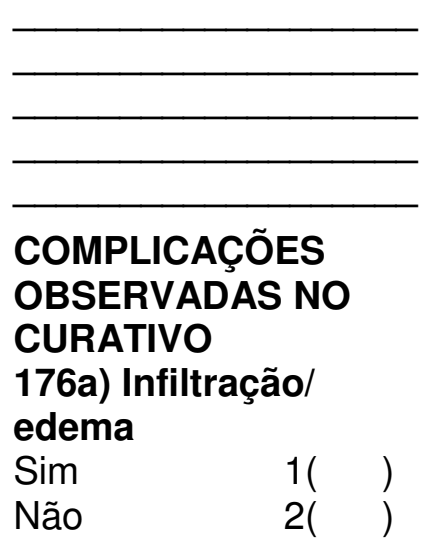

176b) Flebite/celulite

Sim

Não

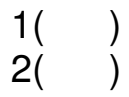

176c) Infecção/septic.

Sim

Não

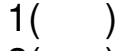

176d) Trombose/

Tromboflebite

Sim

Não

$$
\begin{array}{ll}
1(\quad) \\
2(\quad)
\end{array}
$$

176e) Obstrução/ oclusão

Sim

Não

$$
\begin{array}{ll}
1(\quad) \\
2(\quad)
\end{array}
$$

176f) Embolia gasosa

Sim

Não 176g) Deslocamento cateter

Sim

Não

$1(\quad)$
$2(\quad)$

176h) Fraturas/

Ruptura

Sim

Não

$1(\quad)$
$2(\quad)$

176i) Migração da ponta

Sim

Não

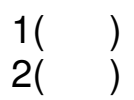

176j) Tamponamento cardíaco

Sim

Não

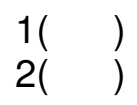

176I) Sangramento

Sim

Não

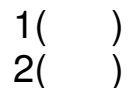

$176 \mathrm{~m})$ outras

Sim

Não

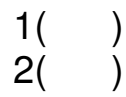

Se outros preencha o próximo campo quais

176ma) Quais 


\begin{tabular}{|c|}
\hline $\begin{array}{l}\text { Segundo curativo } \\
\text { 270) Data }\end{array}$ \\
\hline 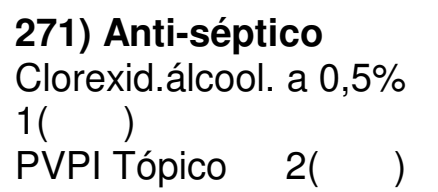 \\
\hline $\begin{array}{l}\text { 272) Tipo de curativo } \\
\text { Fita estéril c/ transp.1( } \\
\text { Fita estéril c/ gaze 2( }\end{array}$ \\
\hline 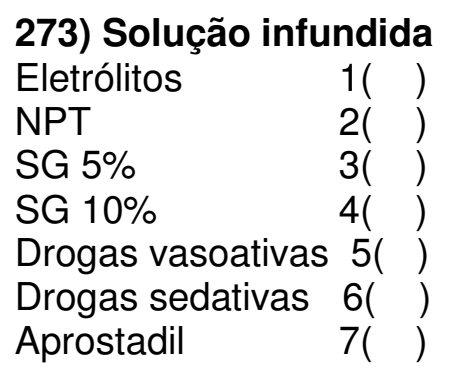 \\
\hline
\end{tabular}

274) Uso de ATB

Sim

1()

Não

2( )

CARACTERÍSTICAS OBSERVADAS NO CURATIVO

275a) Permeabilidade

Sim

Não

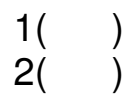

275b) Uso de Tala

Sim

Não

$1(\quad)$
$2(\quad)$

275c) Endurecimento

Sim

Não

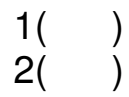

275d) Hematoma

Sim

Não

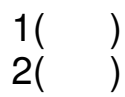

275e) Secreção

Sim

Não 275f) Hiperemia

$\begin{array}{ll}\text { Sim } & 1(\quad) \\ \text { Não } & 2(\quad)\end{array}$

275g) Presença de dobras

Sim

Não

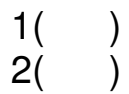

275h) outros

Sim

Não

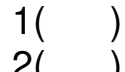

Se outros preencha o próximo campo quais

275ha) Quais

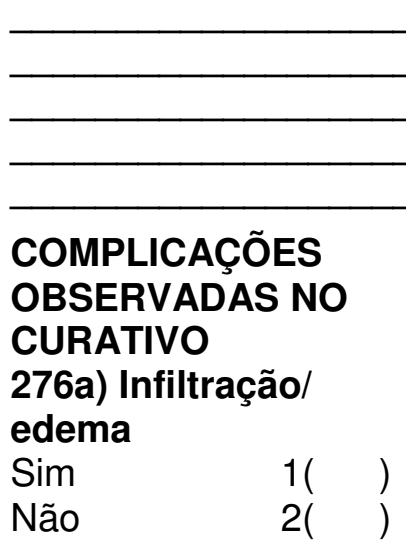

276b) Flebite/celulite

Sim

Não

$1(\quad)$
$2(\quad)$

276c) Infecção/

septicemia

Sim

Não

276d) Trombose/ tromboflebite

Sim

Não

$1(\quad)$
$2(\quad)$

276e) Obstrução/ obstrução

Sim

Não

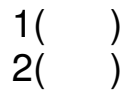

276f) Embolia gasosa

Sim

Não 276g) Deslocamento cateter

Sim

Não

$1(\quad)$
$2(\quad)$

276h) Fraturas/

rupturas

Sim

Não

$1(\quad)$
$2(\quad)$

276i) Migração da ponta

Sim

Não

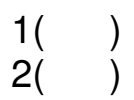

276j) Tamponamento cardíaco

Sim

Não

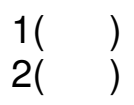

276I) Sangramento

Sim

Não

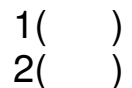

276m) outras

Sim

Não

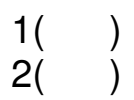

Se outros preencha o próximo campo quais

276ma) Quais 
Terceiro curativo

370) Data

371) Anti-séptico

Clorexid.álcool. a 0,5\%

1( )

PVPI Tópico 2( ）

372) Tipo de curativo

Fita estéril c/ transp1( )

Fita estéril c/ gaze 2(

373) Solução infundida

Eletrólitos

NPT

SG $5 \%$

SG $10 \%$

Drogas vasoativas 5

Drogas sedativas 6( )

Aprostadil

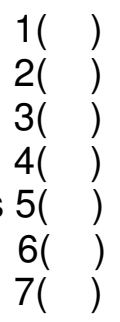

374) Uso de ATB

Sim

Não

$$
\begin{array}{ll}
1(\quad) \\
2(\quad)
\end{array}
$$

CARACTERÍSTICAS

OBSERVADAS NO

CURATIVO

375a) Permeabilidade

Sim

Não<smiles>[Te][Te][Tl]</smiles>

375b) Uso de Tala

Sim

Não

$$
\begin{array}{ll}
1(\quad) \\
2(\quad)
\end{array}
$$

375c) Endurecimento

Sim

Não

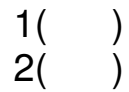

375d) Hematoma

Sim

Não

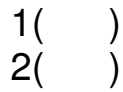

375e) Secreção

Sim

Não

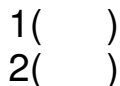

375f) Hiperemia

Sim

Não 375g) Presença de dobras

Sim

Não

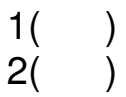

$375 h)$ outros

Sim

Não

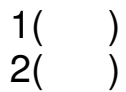

Se outros preencha o próximo campo quais

375ha) Quais

COMPLICAÇÕES OBSERVADAS NO CURATIVO

376a) Infiltração/ edema

Sim

Não

$1(\quad)$
$2(\quad)$

376b) Flebite/ celulite

Sim

Não

$1(\quad)$
$2(\quad)$

376c) Infecção/ septicemia

Sim

Não

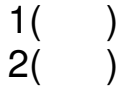

376d) Trombose/ tromboflebite

Sim

Não

$1(\quad)$
$2(\quad)$

376e) Obstrução/ oclusão

Sim

Não

$1(\quad)$
$2(\quad)$

376f) Embolia gasosa

Sim

Não 376g) Deslocamento cateter

Sim

Não

$$
\begin{array}{ll}
1( & ) \\
2( & )
\end{array}
$$

376h) Fraturas/

ruptura

Sim

Não

$1(\quad)$
$2(\quad)$

376i) Migração da ponta

Sim

Não

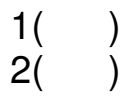

376j) Tamponamento cardia

Sim

Não

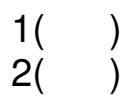

376I) Sangramento

Sim

Não

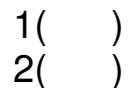

$376 \mathrm{~m}$ ) outras

Sim

Não

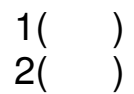

Se outros preencha o próximo campo quais

376ma) Quais 
Quarto curativo

470) Data

471) Anti-séptico

Clorexid.álcool. a 0,5\%

$1(\quad)$

PVPI Tópico 2( )

472) Tipo de curativo

Fita estéril c/ transp1(

Fita estéril c/ gaze 2(

473) Solução infundida

Eletrólitos

NPT

SG $5 \%$

SG $10 \%$

Drogas vasoativas $5($ )

Drogas sedativas $5($ )

Aprostadil

1()
2()
3()
4()
5()
6()
7()

474) Uso de ATB

Sim

Não

$$
\text { 1( ) }
$$

CARACTERÍSTICAS

OBSERVADAS NO

CURATIVO

475a) Permeabilidade

Sim

Não

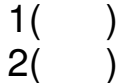

475b) Uso de Tala

Sim

Não

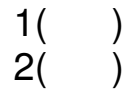

475c) Endurecimento

Sim

Não

$$
\begin{array}{ll}
1( & \\
2( & )
\end{array}
$$

475d) Hematoma

Sim

Não

$$
\begin{array}{ll}
1( & ) \\
2( & )
\end{array}
$$

475e) Secreção

Sim

Não

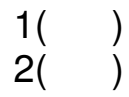

475f) Hiperemia

Sim

Não 475g) Presença de dobras

Sim

Não

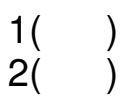

475h) outros

Sim

Não

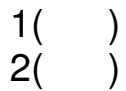

Se outros preencha o próximo campo quais

475ha) Quais

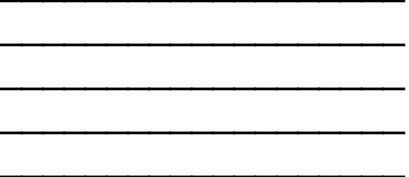

COMPLICAÇÕES

OBSERVADAS NO

CURATIVO

476a) Infiltração/

edema

Sim

Não

$\begin{array}{ll}1( & \\ 2( & )\end{array}$

476b) Flebite/ celutite

Sim

Não

1( )

476c) Infecção/

septicemia

Sim

Não

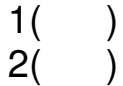

476d) Trombose/ tromboflebite

Sim

Não

$$
\text { 2) }
$$

476e) Obstrução/

\section{Oclusão}

Sim

Não

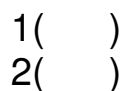

476f) Embolia gasosa

Sim

Não 476g) Deslocamento cateter

Sim

Não

$$
\begin{array}{ll}
1( & \text { ) } \\
2( & )
\end{array}
$$

476h) Fraturas/ rupturas

Sim

Não

1( )

476i) Migração da ponta

Sim

Não

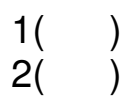

476j) Tamponamento cardíaco

Sim

Não

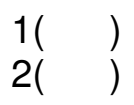

476I) Sangramento

Sim

Não

476m) outras

Sim

Não

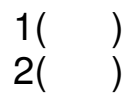

Se outros preencha o próximo campo quais

476ma) Quais 


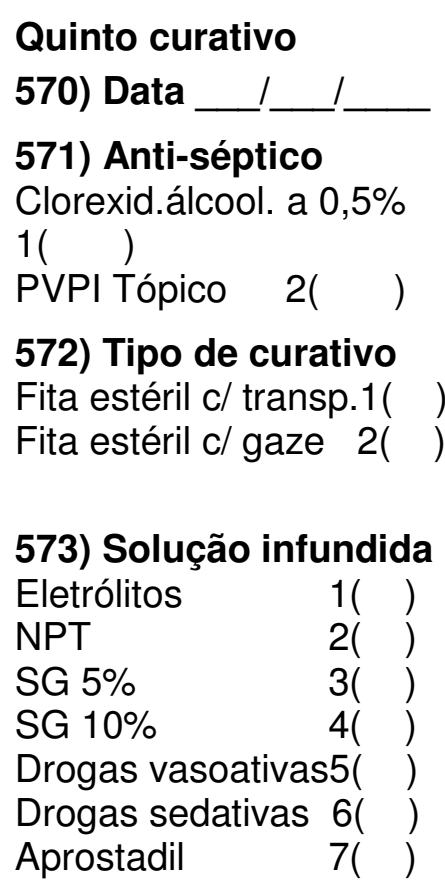

574) Uso de ATB

Sim

Não

$$
\begin{array}{ll}
1(\quad) \\
2(\quad)
\end{array}
$$

CARACTERÍSTICAS OBSERVADAS NO CURATIVO

575a) Permeabilidade

Sim

Não

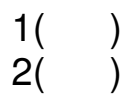

575b) Uso de Tala

Sim

Não

$1(\quad)$
$2(\quad)$

575c) Endurecimento

Sim $1(\quad)$

Não 2( )

575d) Hematoma

Sim

Não

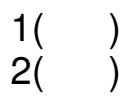

575e) Secreção

Sim

Não 575f) Hiperemia

$\begin{array}{ll}\text { Sim } & 1(\quad) \\ \text { Não } & 2(\quad)\end{array}$

575g) Presença de dobras

Sim

Não

$\begin{array}{ll}1( & ) \\ 2( & )\end{array}$

575h) outros

Sim

Não

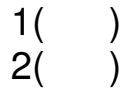

Se outros preencha o próximo campo quais

575ha) Quais

\section{COMPLICAÇÕES}

OBSERVADAS NO

CURATIVO

576a) Infiltração/

edema

Sim

Não

$1(\quad)$
$2(\quad)$

576b) Flebite/ celulite

Sim

Não

$1(\quad)$
$2(\quad)$

576c) Infecção/ septicemia

Sim

Não

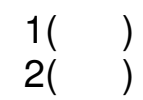

576d) Trombose/ tromboflebite

Sim

Não

$1(\quad)$
$2(\quad)$

576e) Obstrução/ oclusão

Sim

Não

$1(\quad)$
$2(\quad)$

576f) Embolia gasosa Sim Não 576g) Deslocamento cateter

Sim

Não

$$
\begin{array}{ll}
1(\quad) \\
2(\quad)
\end{array}
$$

576h) Fraturas/ rupturas

Sim

Não

576i) Migração da ponta

Sim

Não

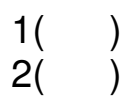

576j) Tamponamento cardíaco

Sim

Não

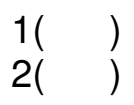

576I) Sangramento

Sim

Não

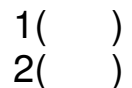

$576 \mathrm{~m})$ outras

Sim

Não

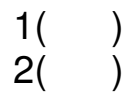

Se outros preencha o próximo campo quais

576ma) Quais 
REMOÇÃO DO

CATETER

80) Data

81) Característica do cateter

Amolecido

Endurecido

Íntegro

$\begin{array}{ll}1( & \\ 2( & ) \\ 3( & )\end{array}$

82) Comprimento total

\section{$(\quad)$}

83) intercorrência

Sim

Não

$\begin{array}{ll}1( & ) \\ 2( & )\end{array}$

Se sim preencha quais

83a) Quais

Embolia Gasosa 1()

Rompimento do PICC 2()

Aderênc. parede vasc 3( )

Espasmo Venoso

$4($ )

Arritmia

Outros

5 ( )

83aa) Quais

Motivos da remoção

84a)Término da

$\begin{array}{lll}\text { terapia } & \\ \text { Sim } & 1(\quad) \\ \text { Não } & 2(\quad)\end{array}$

84b)Obstrução

Sim

Não

84c)Infecção

Sim

Não

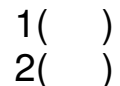

84d)Aum. Cincunf membro

Sim

Não
84e)Exteriorização

$\begin{array}{lll}\text { Sim } & 1(\quad) \\ \text { Não } & 2(\quad)\end{array}$

84f)Extravazamento local

Sim

Não

$1(\quad)$

2( )

84g)Fratura

Sim

Não

$1(\quad)$
$2(\quad)$

84h)Óbito

Sim

Não

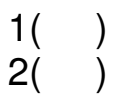

84i)Outros

Sim

Não

$1(\quad)$
$2(\quad)$

84ia)quais

85) Cultura da ponta do cateter

Sim

Não

$1(\quad)$
2()

Se sim preencha quais

microorganismos

\section{5a) Qual}

Estafilococos coagulase negativa

Serratia marcescens 2( )

Enterobacter cloacae 3( )

Estafilococcos

Epidermidis

Enterobacter

Aerogenes

4( )

Outros

85aa) Quais outros

86) Hemocultura positiva

Sim

Não

Se sim preencha quais

microorganismos

\section{6a)Qual}

Estafilococos coagulase negativa

Serratia marcescens 2( )

Enterobacter cloacae 3( )

Estafilococos

epidermidis

Enterobacter

aerogenes

5( )

Outros

86aa) Quais outros 


\section{HOSPITAL DAS CLÍNICAS}

DA

FACULDADE DE MEDICINA DA UNIVERSIDADE DE SÃO PAULO

\section{TERMO DE CONSENTIMENTO LIVRE E ESCLARECIDO}

(Instruções para preenchimento no verso)

\section{I - DADOS DE IDENTIFICAÇÃO DO SUJEITO DA PESQUISA OU RESPONSÁVEL LEGAL}

1. NOME DO PACIENTE:

DOCUMENTO DE IDENTIDADE № : SEXO : $M$

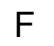

DATA NASCIMENTO: ................

ENDEREÇO .... APTO:

BAIRRO: CIDADE ..CE

$P$ : TELEFONE:DDD ..)...

2.RESPONSÁVEL LEGAL

NATUREZA (grau de parentesco, tutor, curador etc.). DOCUMENTO DE IDENTIDADE : DATA NASCIMENTO.: ..................... ENDEREÇO:. BAIRRO: CEP: ..№. SEXO: $\mathrm{M}$ APTO: CIDADE:

\section{II - DADOS SOBRE A PESQUISA CIENTÍFICA}

1. TÍTULO DO PROTOCOLO DE PESQUISA .Práticas de inserção, manutenção e remoção do cateter PICC em recém-nascidos internados em uma unidade de terapia intensiva

\section{PESQUISADOR: Amélia Fumiko Kimura}

Patricia Ponce de Camargo.

CARGO/FUNÇÃO: Professora Dra da Escola de Enfermagem da Universidade de São Paulo INSCRIÇÃO CONSELHO REGIONAL № COREN 22595.

3. AVALIAÇÃO DO RISCO DA PESQUISA:

$\begin{array}{lcc}\text { SEM RISCO } \quad X \quad \text { RISCO MÍNIMO } & \square \quad \text { RISCO MÉDIO } \\ \text { RISCO BAIXO } & \text { RISCO MAIOR } \square\end{array}$

(probabilidade de que o indivíduo sofra algum dano como conseqüência imediata ou tardia do estudo) 
4.DURAÇÃO DA PESQUISA : 2 anos.

\section{III - REGISTRO DAS EXPLICAÇÕES DO PESQUISADOR AO PACIENTE OU SEU REPRESENTANTE LEGAL SOBRE A PESQUISA, CONSIGNANDO:}

1. Gostaria de sua autorização para incluir o seu filho (a) em um trabalho que estou realizando no berçário. O seu bebê está internado na UTI e precisou receber soro na veia. Como as veias dos bebês são frágeis, para que o bebê não sofresse muitas picadas, a enfermeira usou uma agulha especial chamada de cateter PICC, que oferece mais conforto ao bebê, causa menos sofrimento e dor na criança e dura mais tempo na veia.

2. No meu estudo vou observar as enfermeiras ao passar o cateter na veia do seu bebê. Vou estudar como é feito o curativo, a lavagem e a manutenção deste cateter até a sua retirada. Não serão feitos nenhum manuseio a mais do que o realizado normalmente no dia a dia.

3. Não há riscos ou outras complicações para o seu bebê com esse estudo.

4. Com esse estudo poderemos confirmar se o cateter PICC ajuda a diminuir o tempo de internação do bebê, trazendo para ele vários efeitos positivos (benéficos). $O$ (a) senhor (a) é livre para decidir se autoriza ou não o uso das informações do meu estudo. Qualquer que seja a sua decisão não interferirá no tratamento do bebê ou no atendimento dado ao senhor (a).

\section{IV - ESCLARECIMENTOS DADOS PELO PESQUISADOR SOBRE GARANTIAS DO SUJEITO DA PESQUISA:}

1. acesso, a qualquer tempo, às informações sobre procedimentos, riscos e benefícios relacionados à pesquisa, inclusive para dirimir eventuais dúvidas.

2. liberdade de retirar seu consentimento a qualquer momento e de deixar de participar do estudo, sem que isto traga prejuízo à continuidade da assistência.

3. salvaguarda da confidencialidade, sigilo e privacidade.

4. disponibilidade de assistência no HCFMUSP, por eventuais danos à saúde, decorrentes do procedimento a ser observado pela pesquisa.

5. não se prevê o pagamento de indenização por eventuais danos à saúde decorrente da pesquisa, já que a pesquisadora não realizará nenhuma intervenção exclusivamente para obter dados, por se tratar de um estudo observacional. 
V. INFORMAÇÕES DE NOMES, ENDEREÇOS E TELEFONES DOS RESPONSÁVEIS PELO ACOMPANHAMENTO DA PESQUISA, PARA CONTATO EM CASO DE INTERCORRÊNCIAS CLÍNICAS E REAÇÕES ADVERSAS.

Profa. Dra Amélia Fumiko Kimura 3066-7602

Enfa. Patrícia Ponce de Camargo 5539-3396 / 3069-6081 / 3069-6395 / 8561-6707

\section{VII - CONSENTIMENTO PÓS-ESCLARECIDO}

Declaro que, após convenientemente esclarecido pelo pesquisador e ter entendido o que me foi explicado, consinto em participar do presente Protocolo de Pesquisa

São Paulo, de . . de 2 .......... 


\section{Termo de Consentimento Livre Esclarecido}

Estou ciente do tema e do objetivo do projeto de pesquisa "Caracterização das práticas de inserção, manutenção e remoção do cateter PICC em recém-nascidos internados em uma Unidade de Terapia Intensiva Neonatal" desenvolvido pela Patrícia Ponce de Camargo, sob orientação da Prof $^{a}$ Dra Amélia Fumiko Kimura do Programa de Pós-Graduação da Escola de Enfermagem da USP.

Fui esclarecida que os dados da pesquisa serão coletados pela própria autora ou por outro profissional devidamente treinado para tal, na ausência da mesma, por meio de observação dos procedimentos de inserção, manutenção e remoção do cateter PICC realizado pelas enfermeiras qualificadas nessa prática.

Estou ciente de que os resultados deste estudo farão parte da dissertação de mestrado e serão divulgados em publicações e eventos de caráter técnico-científico, sendo-me garantido que o meu nome não será mencionado e que poderei desistir de participar do estudo em qualquer momento, se assim o desejar, sem sofrer quaisquer prejuízos.

Poderei solicitar esclarecimentos sobre o estudo à autora pelos telefones: 5539-3396; 8561-6707, à orientadora do Programa de Programa de Pós-Graduação da Escola de Enfermagem da USP pelo telefone 3066-7602 ou com a Comissão de Ética para Análise de Projetos de Pesquisa-Cappesq do Hospital das Clínicas da Faculdade de Medicina da Universidade de São Paulo no telefone 30698804 .

Consinto participar do estudo e assino este documento em duas vias. Uma cópia ficará em meu poder e a segunda com a pesquisadora.

São Paulo, de de 200

Assinatura da enfermeira 


\begin{tabular}{lll}
\hline MFN: $0526 \quad$ PROPES.MST & P
\end{tabular}

Num. do Protocolo:

Data de Entrada:

Autor Responsavel:

Autores:

Linha de Pesquisa:

Descrição:

Titulo do Projeto:

Descrição:

Tipo:

Unidade(s) Executora(s):

Prazo Inicio:

Prazo Termino:

Chefia de Area:

Comissão de Pesquisa:

Relator Comissão:

Chefe departamento:

Tipo:
00526200604

02 / 02 / 2006

Amélia Fumiko Kimura (Kimura AF)

Amélia Fumiko Kimura (Kimura AF)

Patrícia Ponce de Camargo (Camargo PP)

Métodos diagnósticos e terapêuticos na abordagem das infecções congênitas, perinatais e adquirida

Estudo dos métodos diagnósticos mais recentes e suas bases moleculares e terapêuticas aplicadas na condução das infecções congênitas (transmissão vertical), perinatais e adquiridas no feto, recém-nascido e adolescente.

Prática de inserção, manutenção e remoção do cateter PICC em recém-nascidos internados em uma Unidade de Terapia Intensiva Neonatal.

O uso do cateter central de inserção periférica (PICC) é um dispositivo que permite fornecimento de nutrição parenteral e é utilizado para tratamento parenteral prolongado em recém-nascidos de termo e pré-termo em estado crítico. O paciente neonatal requer cuidados específicos e intensivos para a instalação e manutenção do PICC, sendo parte integrante e fundamental da assistência da equipe de enfermagem na unidade de cuidado intensivo neonatal. Apesar de todas as suas vantagens - menor número de punções venosas, menor taxa de infecção, redução do custo, facilidade de inserção, possibilidade de múltiplos locais de inserção, melhor evolução clínica - a inserção do PICC não é isenta de complicações, dentre as quais pode se citar: deslocamento do cateter, flebite, celulite, obstrução, tamponamento cardíaco, etc. Serão incluidos todos os recém-nascidos admitidos no Berçário Anexo à Maternidade do ICr-HCFMUSP, submetidos ao procedimento de inserção do PICC, após autorização dos pais e ou responsáveis e as enfermeiras habilitadas na inserção do PICC com prévia autorização das mesmas. Serão excluídos apenas os recém-nascidos cujo procedimento de inserção do cateter seja realizado pela autora (pesquisadora). Será feito uma entrevista com a enfermeira responsável pela inserção do PICC a fim de verificar se houve dificuldades na inserção e na remoção do cateter.

Pesquisa clínica - entrevistas e questionários

Berçário Anexo à Maternidade ICHC

$00 / 03 / 2006$

$00 / 06 / 2007$

Exeqüivel Vera Lúcia Jornada Krebs 26/01/2006

Aprovado Magda Maria Sales Carneiro Sampaio 24/02/2006

Aprovado Renata Amato Vieira 24/02/2006

Flávio Adolfo Costa Vaz

Dissertação de Mestrado - Área de Enfermagem 
